\title{
1. INTRODUCTION, BACKGROUND, AND PRINCIPAL RESULTS OF LEG 128 OF THE OCEAN DRILLING PROGRAM, JAPAN SEA ${ }^{1}$
}

\author{
Shipboard Scientific Party ${ }^{2}$
}

\section{INTRODUCTION}

The Japan Sea has been widely viewed as a prime example of a back-arc basin ever since the emergence of plate tectonic concepts of convergent margin evolution (Karig, 1971). Abyssal water depths exceeding $3000 \mathrm{~m}$ point to oceanic crust beneath the western portions of the sea (Figs. 1 and 2). In contrast, tectonically emplaced shallow sills $(<150 \mathrm{~m})$ separate the sea from the adjacent Pacific Ocean and dictate its unusual oceanographic behavior (Fig. 1). The geology and geophysical structure of the Japanese Islands leave no doubt regarding the presence of continental crust beneath the Japan Arc, and multiple evidence demonstrates that structurally isolated continental fragments are present in the Japan Sea proper. These features in turn demand tectonic separation of the arc from mainland Asia via continental rifting and back-arc formation of the sea. However, the age and style of this event remain obscure, despite intense study of the Japan Sea region over the past half century.

In 1973, scientists of Leg 31 of the Deep Sea Drilling Project attempted to core and date basement rocks beneath the Japan Sea to constrain the age of its formation (Karig, Ingle, et al., 1975). Unfortunately, gas shows and other problems caused them to halt drilling prior to complete penetration of the sedimentary cover, leaving fundamental questions about the age and evolution of the sea unanswered-and coincidentally setting the stage for Ocean Drilling Program (ODP) drilling in the Japan Sea some 16 years later.

Leg 128 represented the second of two ODP legs devoted to probing the evolution of the Japan Sea. In effect, Leg 128 and the preceding Leg 127 constituted a single expedition, with the unifying objectives of (1) detailing the style and dynamics of marginal sea formation in a continental arc setting and (2) deciphering the parallel sedimentary-paleoceanographic history of the sea as it developed in response to major tectonic, depositional, and climatic events that shaped the sea and dictated the character of the water masses within its basins. Scientists of Leg 127 drilled four basinal sites in the summer of 1989 and successfully recovered volcanic and sedimentary rocks representing acoustic basement, along with continuous sequences through Miocene, Pliocene, and Quaternary sediments that fill the Yamato and northern Japan basins (Fig. 2).

Leg 128 scientists spent the early fall of 1989 drilling two major topographic and structural highs and one basinal site shared with Leg 127 (Fig. 2 and Table 1). The primary goals of Leg 128 were (1) to recover a paleoceanographic reference section atop Oki Ridge (Site 798), (2) to core the Kita-Yamato Trough, thought to represent a failed-rift within the larger Yamato Rise and a typical setting for deposition of volcanogenic massive sulfides (Site 799), and (3) to re-occupy Site 794

\footnotetext{
${ }^{1}$ Ingle, J. C., Jr., Suyehiro, K., von Breymann, M. T., et al., 1990. Proc. ODP, Init. Repts., 128: College Station, TX (Ocean Drilling Program).

${ }^{2}$ Shipboard Scientific Party is as given in list of participants preceding the contents.
}

in the northern Yamato Basin, first drilled during Leg 127, to conduct two major geophysical experiments aimed at detailing the structure of the deep crust and upper mantle beneath the Japan Sea (Fig. 2). We successfully accomplished all of these tasks. In addition, we cored $190 \mathrm{~m}$ into the Miocene volcanic basement sequence beneath Site 794, initially penetrated during Leg 127, and conducted a pioneering microbiological sampling program at Site 798 to establish the distribution and role of bacteria in the diagenesis of deep marine sediments.

The new data amassed through Legs 127 and 128 drilling and through geophysical experiments provide heretofore unavailable constraints on the timing, rates, and style of formation of the deep basins, ridges, and rises of the eastern and central Japan Sea. Distinctive lithofacies encountered at all sites clearly reflect both major episodes of subsidence and uplift, as well as the paleoceanographic history of the sea. In particular, repeated occurrences of organic-rich sediments and basin-wide deposition of distinctive biogenous pelagichemipelagic sediments document major changes in the circulation, chemistry, and productivity of the sea, including apparent shifts from near-anoxic conditions to fully oxic modes of operation.

Because Legs 127 and 128 shared complimentary goals and a unifying theme, the Initial Reports volumes stemming from these two cruises necessarily overlap in their coverage of some topics. Although we have attempted to minimize repetition of background material presented by Tamaki, Pisciotto, Allan, et al. (in press), some duplication is necessary to provide an adequate overview of the Japan Sea. These latter authors present an extensive review of the tectonic setting and origins of the Japan Sea in the Initial Reports volume for Leg 127. Alternatively, we include background material on the modern oceanography of the sea and the geology of the Miocene Kuroko massive sulfide deposits of Japan as appropriate to specific Leg 128 objectives. Hence, the interested reader is urged to have both Leg 127 and Leg 128 Initial Reports volumes at hand to gain a complete perspective of the background, results, and interpretations afforded by all six ODP sites drilled in the Japan Sea. However, we realize that some readers will not have simultaneous access to both volumes; thus, we have drawn freely on the tectonic and geologic background data and illustrations presented by Tamaki, Pisciotto, Allan, et al. (in press) in our introductory statements on these topics.

This chapter provides summary information on the background, objectives, and principal shipboard results of Leg 128. Detailed reports of our findings are presented in following chapters.

\section{BACKGROUND}

\section{Introduction}

A wide array of back-arc basins have evolved between the North American, Pacific, Eurasian, and Australian plates over the past $60 \mathrm{~m}$. y., and the resulting marginal seas now characterize the western margin of the Pacific Ocean (Fig. 3). 


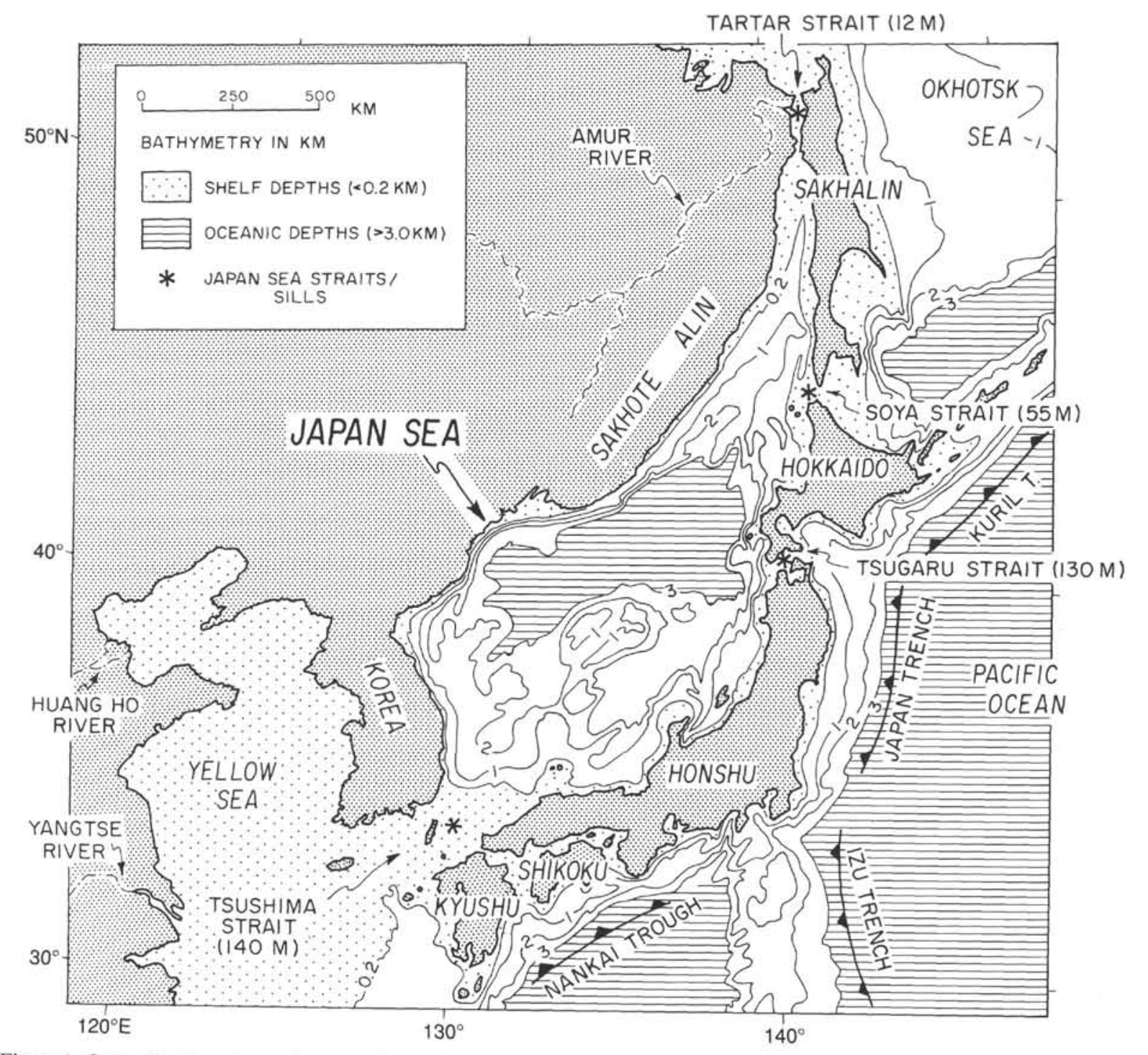

Figure 1. General bathymetry and geography of the Japan Sea and surrounding region, including the Yellow and Okhotsk seas. Bathymetry in kilometers; note that isobaths representing water depths in excess of $3 \mathrm{~km}$ in the Pacific Ocean are not shown. Maximum water depths in Japan Sea straits/sills are shown in parentheses.

These basins express multiple origins involving both back-arc spreading induced by various mechanisms associated with the subduction process (e.g., Uyeda, 1986) as well as local responses to regional interplate/intercontinental deformational events (e.g., Kimura and Tamaki, 1986; Jolivet et al., 1989). Essentially, all stages of back-arc evolution are represented within this region, ranging from the tectonically compressed and uplifted basins that form portions of the Philippine Islands to juvenile regimes such as the Woodlark Rift and the Lau Basin, which are currently undergoing active spreading. A number of the back-arc basins in this region have evolved in purely oceanic settings (e.g., Mariana Basin). In contrast, the Japan Sea clearly has evolved in a continental arc setting of special importance for interpreting many ancient convergent margins and associated orogenic belts.

The Japan Sea represents the best studied of the many back-arc basinal complexes rimming the western Pacific, with multiple marine geophysical and geological surveys, DSDP drilling data, and extensive onshore geological data from the surrounding areas of Japan, Korea, and the U.S.S.R. provid- ing an unusually rich context in which to interpret its history. These data collectively indicate that the Japan Sea began to form by continental rifting in mid-Tertiary time, was fully developed via back-arc spreading by middle Miocene time, and is now in the initial stage of compressive deformation and collapse. As a direct consequence of this rapid development, most of the key elements in the evolution of the sea are still in place and have been sampled by pick, drill, and/or geophysical means.

Bathymetric and heat flow data, along with seismic refraction and reflection profiles, indicate that the deep floors of the sea are underlain by crust of oceanic and transitional thickness (Figs. 4 through 9). In addition, dredge hauls confirm that some intervening highs in the sea represent rifted blocks of continental material presumably isolated during initial backarc spreading, as exemplified by the Yamato Rise (Figs. 7 and 8). However, prior to ODP drilling, basement rocks underlying the Japan and Yamato basins remained unsampled, leading to continued controversy over the evolution of the sea, with estimates of its age of formation ranging from Cretaceous to 


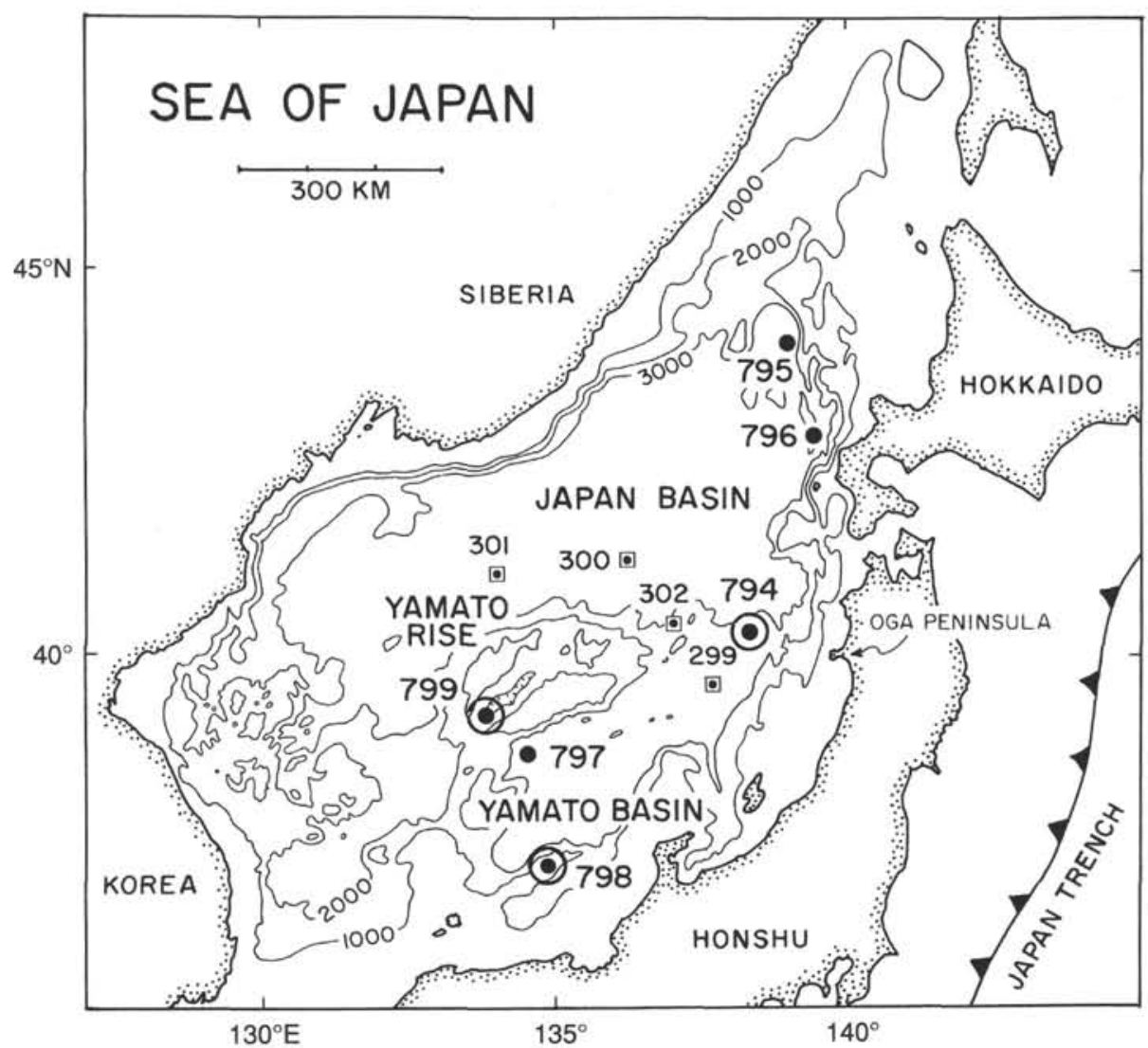

Figure 2. Location map of the Japan Sea showing Leg 128 Sites 794, 798, and 799 (circled dots), Leg 127 Sites 794 through 799 (dots), DSDP Sites 299 through 302 (boxed dots), and the location of the Oga Peninsula onshore Neogene reference section. Note that Site 794 was occupied during both Legs 127 and 128. Bathymetry in meters.

Table 1. Summary of Leg 128 sites cored in the Japan Sea.

\begin{tabular}{|c|c|c|c|c|c|c|c|c|c|}
\hline Hole & Latitude & Longtitude & $\begin{array}{l}\text { Water depth } \\
\text { (mbsl) }\end{array}$ & $\begin{array}{c}\text { Total } \\
\text { penetration } \\
\text { (mbsf) }\end{array}$ & $\begin{array}{l}\text { Number } \\
\text { of cores }\end{array}$ & $\begin{array}{l}\text { Length } \\
\text { cored } \\
\text { (m) }\end{array}$ & $\begin{array}{l}\text { Length } \\
\text { recovered } \\
\text { (m) }\end{array}$ & $\begin{array}{c}\text { Recovery } \\
(\%)\end{array}$ & $\begin{array}{l}\text { Coring } \\
\text { method }\end{array}$ \\
\hline 794D & 40.18944 & 138.23240 & a $_{2806.9}$ & $b_{733.5}$ & 20 & 160.5 & 34.85 & 21.7 & $\mathrm{RCB}$ \\
\hline$c_{794 E}$ & 40.17553 & 138.23257 & 2800.9 & 400.0 & 0 & 0 & 0 & 0 & Wash \\
\hline $798 \mathrm{~A}$ & 37.03832 & 134.79976 & 903.1 & 143.3 & 17 & 143.3 & 148.27 & 103 & APC \\
\hline $798 \mathrm{~B}$ & 37.03848 & 134.79961 & 900.0 & 517.9 & 54 & 517.9 & 514.42 & 99.3 & $\mathrm{APC} / \mathrm{XCB}$ \\
\hline $798 \mathrm{C}$ & 37.03846 & 134.07991 & 900.1 & 120.1 & 13 & 120.1 & 132.08 & 110.0 & APC \\
\hline $799 \mathrm{~A}$ & 39.22046 & 133.86685 & 2073.0 & 468.7 & 52 & 468.7 & 440.04 & 93.9 & $\mathrm{APC} / \mathrm{XCB}$ \\
\hline $799 \mathrm{~B}$ & 39.22048 & 133.86645 & 2071.7 & $\mathrm{~d}_{1084.0}$ & 67 & 633.0 & 280.48 & 44.3 & $\mathrm{RCB}$ \\
\hline$e^{2} 799 \mathrm{E}$ & 39.22000 & 133.86660 & 2080.0 & 252.5 & 3 & & & & \\
\hline
\end{tabular}

a Depths are drill-pipe measurements corrected to sea level; mbsl = meters below sea level, mbsf = meters below seafloor.

b Began coring at 573 mbsf.

c Dedicated hole for electrical resistivity experiment.

d Began coring at 450 mbsf.

e Dedicated hole for testing experimental sonic core monitoring tool.

late Miocene (e.g., Beloussov, 1968; Uyeda and Miyashiro, 1974; Ludwig et al., 1975; Gnibidenko, 1979; Uyeda and Kanamori, 1979; Kobayashi, 1985; Lallemand and Jolivet, 1985; Tamaki, 1986, 1988; Jolivet et al., 1989).

Magnetic anomalies in the eastern Japan Sea are poorly developed and cannot be used to estimate the age of the deep floor of the Yamato Basin (Fig. 10) probably because of the masking effect of the thickened oceanic or transitional crust present in this basin (Tamaki, 1988; Katao, 1988). However, coherent northeast-southwest linear anomalies are present in the Japan Basin, presumably marking the positions of the rapidly propagating spreading ridges that formed the floor of this basin. These latter anomaly patterns have recently been correlated with the magnetic reversal time scale to yield an estimated maximum late Oligocene age of $26 \mathrm{Ma}$ for this basin (Tamaki and Kobayashi, 1988; Fig. 2). Indeed, the bulk of the offshore and onshore evidence available prior to ODP drilling, including heat flow, extrapolated rates of sediment accumulation, and basement depths, all suggested that the formation of the Japan Sea occurred in late Oligocene to early Miocene time (e.g., Tamaki, 1986, 1988; Kimura and Tamaki, 1986; Chinzei, 1986a, 1986b). In addition, paleomagnetic studies of 


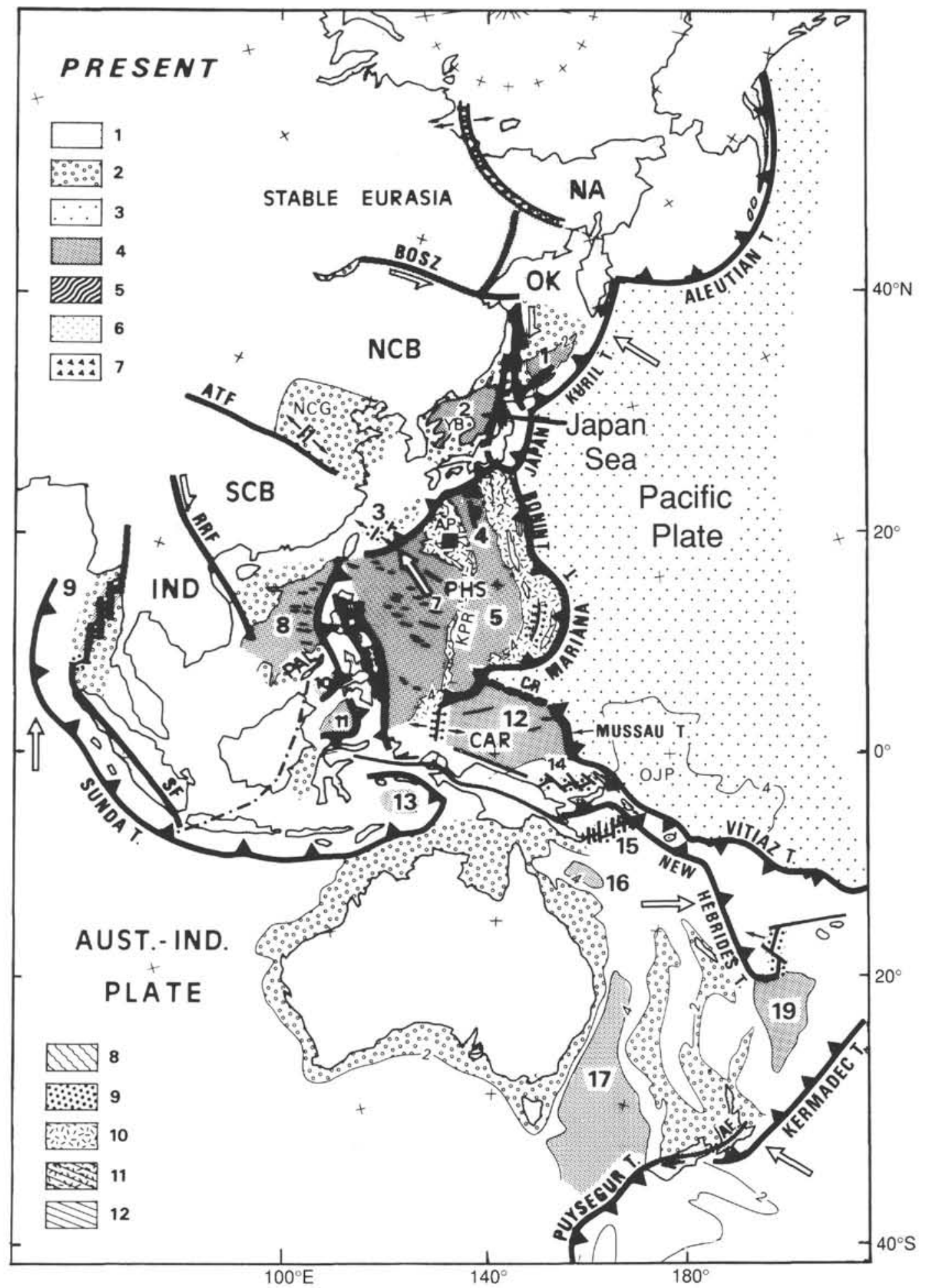

Figure 3. Tectonic map of the western Pacific Ocean region showing locations of marginal seas and basins in relation to major crustal plates and subduction zones. Figure modified from Jolivet et al. (1989). 1 to 19: marginal basins. 1-Kuril basin, 2-Sea of Japan, 3-Okinawa basin, 4-Shikoku basin, 5-Parece Vela basin, 6-Mariana basin, 7-West Phillipine basin, 8-South China Sea, 9-Andaman Sea, 10-Sula Sea, 11-Celebes basin, 12-Caroline Basin, 13-Banda Sea, 14-Bismark rift, 15-Woodlark rift, 16-Coral Sea, 17-Tasman Sea, 18 -North Fiji basin, 19 -South Fiji basin, $O K$ - Okhotsk plate, $N C B$-North China block, $S C B$-South China block, $I N D$-Indochina block, $A P$-Amami plateau, $K P R-$ Kyushu-Palau ridge, $C R-$ North Caroline ridge, OJP-Ontong Java plateau, BOSZ-Baikai-Okhotsk shear zone, HTSZ-Hidaka-Tartary shear zone, $A T F$-Altyn-Tagh fault, $R R F$ - Red River fault, $S F$ - Sumatra fault, $A F$-Alpine Fault, Black squares in the PHS plate are DSDP sites (445-north, 292-south). Patterns $l$ to $12: 1=$ emerged continental crust, $2=$ stretched continental crust, 3 = Pacific plate, $4=$ marginal basins oceanic crust (extinct), $5=$ Molucca Sea oceanic crust (only on the $12 \mathrm{Ma}$ stage). $6=$ marginal basins oceanic crust (active spreading). $7=$ AUS-ANT plate oceanic crust, $8=$ ANT plate oceanic crust, $9=$ New Guinea plate oceanic crust, $10=$ crust of the Bonin arc and Kyushu-Palau ridge, $11=$ same as 10 , now subducted. 12 = subducted part of the Shikoku basin. 

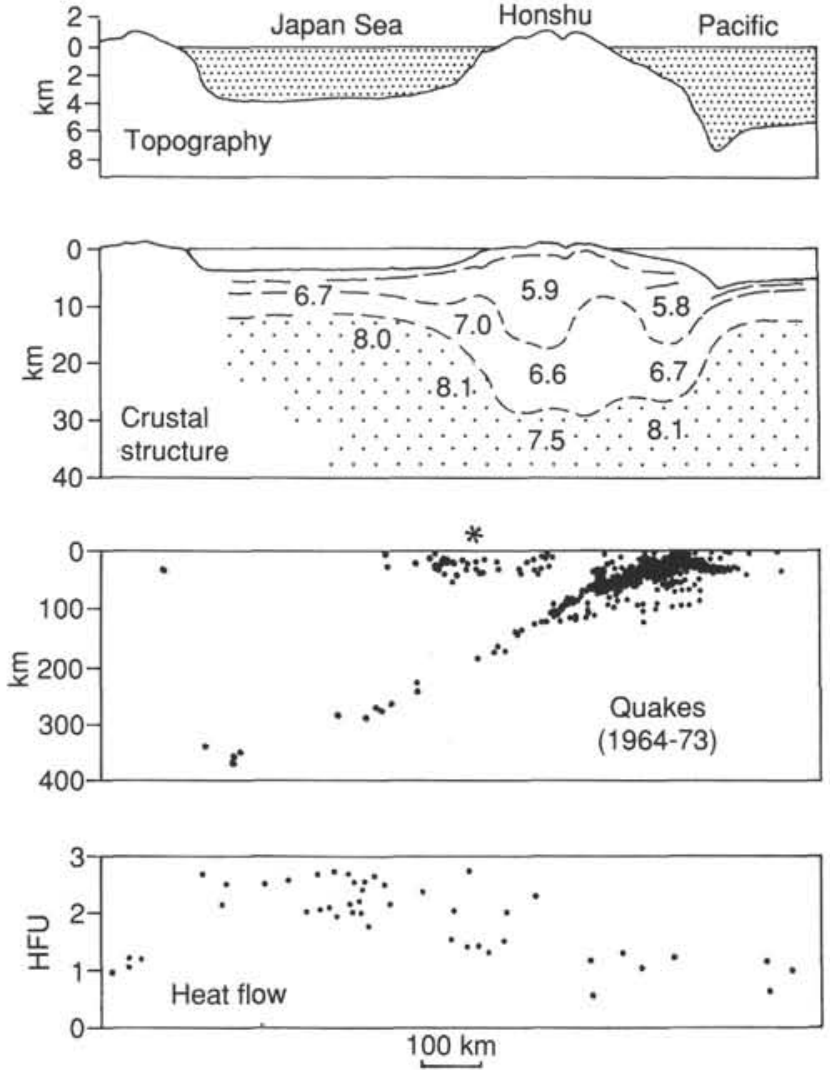

Figure 4. Regional east-west crustal section through the Japan Trench, Japan Arc, and Japan Sea (Japan Basin) illustrating topography, crustal structure and velocities, pattern of deep earthquakes marking subduction of the Pacific Plate, zone of shallow earthquakes associated with tectonic compression in progress along the eastern margin of the Japan Sea (asterisk), and representative heat flow values. Figure modified from Yoshii and Asano (1972).

Miocene rocks on Honshu indicate that southwest Japan experienced rapid clockwise rotation and northeast Japan counter-clockwise rotation between 22 and $11 \mathrm{Ma}$ (Otofuji et al., 1985), with the climax of these events apparently occurring ca. 17 to $15 \mathrm{Ma}$ (Tosha, 1984; Otofuji et al., 1985; Hayashida, 1986; Hirooka, 1987; Otofuji and Matsuda, 1987). All of these reports concluded that the apparent rotations and bending of Honshu were the result of the rapid opening of the Japan Sea sometime between early and early middle Miocene time, as illustrated in a recent paleogeographic reconstruction presented by Taira et al. (1989; Fig. 11).

As the JOIDES Resolution sailed westward through the Tsugaru Strait and into the Japan Sea in August 1989, the critical test of these various ideas and interpretations lay just ahead.

\section{Tectonic Setting}

The regional tectonic map of Jolivet et al. (1989) illustrates that the Japan Sea was formed along the eastern edge of the Eurasian Plate and that it is nested between the Pacific, Philippine, and North American plates, including the Okhotsk and Amurian microplates (Fig. 3). The development of the sea has been directly related to the tensional, compressional, and translational stresses that these four major plates have exerted on this area over the past 30 to $40 \mathrm{~m}$.y. The Japan Trench and its descending pattern of deep quakes beneath the Japan Sea mark the zone of subduction of the Pacific Plate, presumably responsible for arc volcanism, high back-arc heat flow, and the multi-axial spreading that formed the sea (Figs. 1, 3, and 4). A second zone of subduction is expressed by the Nankai Trough, where the northern edge of the Philippine Plate is being thrust beneath southwestern Japan (Fig. 1). Hibbard and Karig (1990) concluded that the collision of this portion of the Philippine Plate with the Eurasian Plate occurred ca. $15 \mathrm{Ma}$ (Fig. 3). The most recent and complex tectonic boundary emerging in the Japan Sea is expressed by a prominent set of north- to northeast-trending ridges, basins, and parallel faults that characterize the eastern margin of the sea (Figs. 1 and 2). Focal mechanism solutions for large compressional earthquakes $(M=6.9$ to 7.7$)$ that have occurred in this zone are consistent with the reverse character of many of the faults bounding the ridges and basins along the western margins of Honshu and Hokkaido (Fukao and Furumoto, 1975; Figs. 2 and 4). Tamaki and Honza (1985) have assembled evidence that suggests that this active tectonic zone may in fact represent a newly developing boundary between the North American and Eurasian plates involving incipient eastward subduction and obduction of back-arc crust and sediments. Leg 127 drilling at Site 796 on the Okushiri Ridge within this zone (Tamaki, Pisciotto, Allan, et al., in press) firmly dated the initial uplift of the ridge as $1.8 \mathrm{Ma}$, in line with other evidence pointing to widespread compressive deformation along the eastern margin of the Japan Sea, beginning in late Pliocene-early Pleistocene time.

\section{Structure}

The deep and shallow structures of the Japan Sea are constrained by seismic reflection and refraction data, as detailed by Tamaki, Pisciotto, Allan, et al. (in press). These authors identified three physiographic provinces within the Japan Sea that clearly reflect basic differences in crustal structure and basin evolution, including (1) the deep basin floors of the Japan and Yamato basins, (2) block-faulted ridges such as the Yamato Rise, and (3) the eastern margin of the sea, characterized by northward-trending en-echelon ridges and silled basins cut and bounded by parallel active faults, as described above (Figs. 1, 2, and 5).

Except for isolated volcanic seamounts, both the Japan and Yamato basins have flat floors that reflect ponding of gravity flow deposits on top of acoustic basement units, which in turn display irregular upper surfaces (Figs. 2, 5, and 7). Water depths of between 3.0 and $3.7 \mathrm{~km}$ suggest that the Japan Basin is underlain by crust of oceanic character-a fact confirmed by both refraction and gravity data, which define a crustal thickness of 11 to $12 \mathrm{~km}$ (Ludwig et al., 1975; Kobayashi, 1985; Figs. 4 and 6). Alternatively, water depths in the smaller Yamato Basin range from 2.0 to $2.5 \mathrm{~km}$, and gravity and refraction data illustrate that this basin is underlain by transitional or intermediate crust that is between 17 and $15 \mathrm{~km}$ thick (Figs. 2 and 6), which Katao (1988) viewed as thickened oceanic-type crust. Tamaki (1988) ascribed the unusually thick crust in the Yamato Basin to the presence of volcaniclastic deposits correlative with the upper Oligocenelower Miocene "Green Tuff' units of Honshu. During Leg 127, drilling penetrated rocks representing acoustic basement beneath the Yamato Basin at ODP Sites 794 and 797 (Tamaki, Pisciotto, Allan, et al., in press; Fig. 2). The rapidly deposited/emplaced Miocene tuffs, basalts, and sedimentary units forming acoustic basement at these sites may account for (1) the anomalously thickened nature of layer 2 characterizing the Yamato Basin (e.g., Tamaki, 1988; Katao, 1988; Hirata et al., in press) and (2) the weak and disorganized nature of magnetic anomalies recorded in the basin (Fig. 10). 


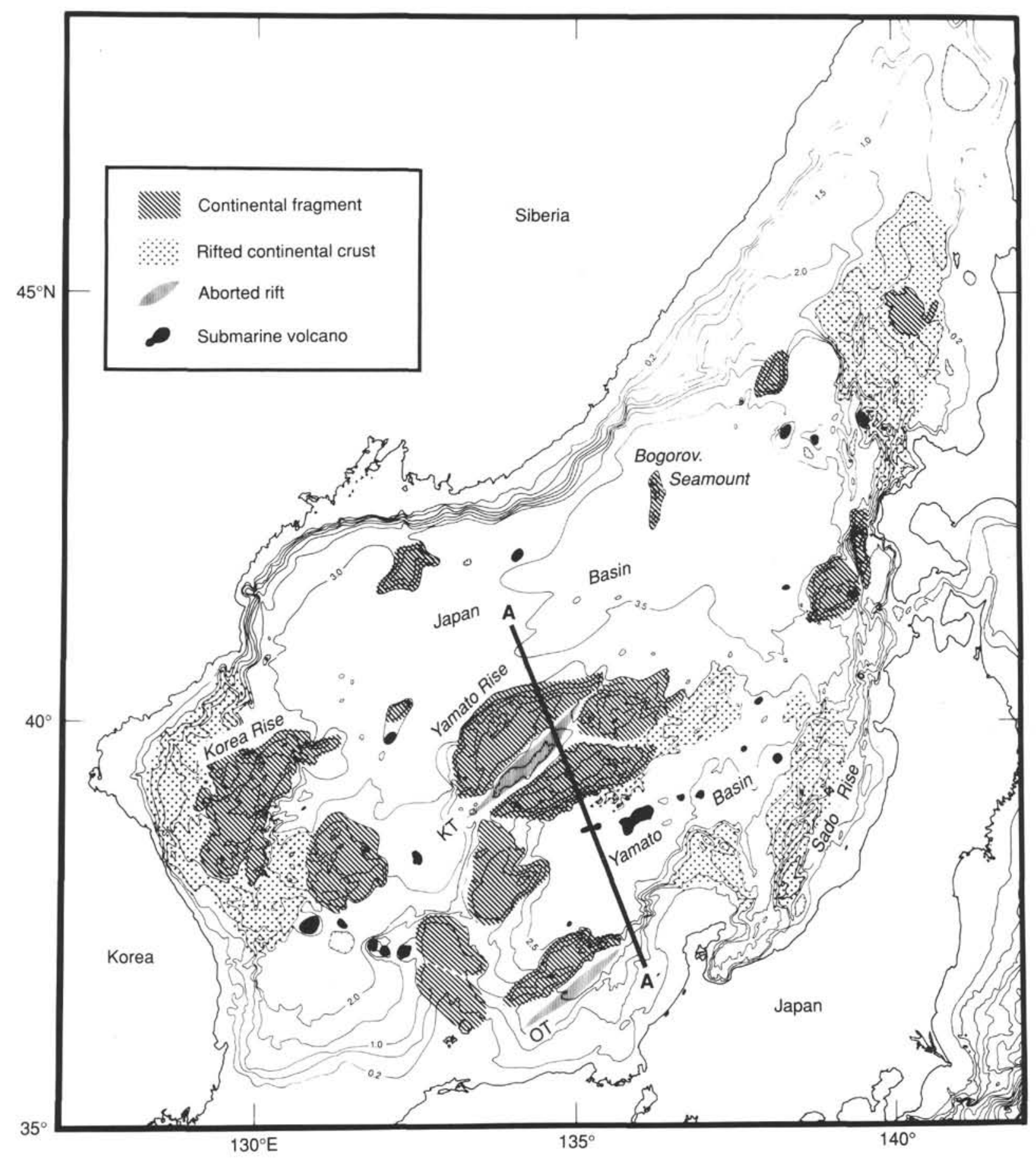

Figure 5. Geological classification of bathymetric highs in the Japan Sea and location of crustal section A-A' shown in Figure 6. Figure from Tamaki (1988). Bathymetry given in kilometers.

On a larger scale, dispersion of surface waves in the Japan Sea area indicates that the lithosphere is only 30 to $40 \mathrm{~km}$ thick beneath the sea (Abe and Kanamori, 1970; Fig. 6), which is consistent with the relatively high heat flow measured in the back-arc area (Kobayashi, 1985; Fig. 9). In addition, free-air gravity anomalies in the Japan and Yamato basins are near zero, indicating that both basins are currently in isostatic equilibrium (Iomoda and Fujimoto, 1982).

Multiple dredge hauls, seismic reflection and refraction data, and gravity data all demonstrate that a number of the large topographic highs and plateaus in the Japan Sea are in fact rifted continental fragments that were presumably isolated during early spreading in the proto-Japan Sea (Tamaki, 1988; Fig. 5). The Yamato Rise is the most prominent and best known of these features, which are commonly bounded and pierced by normal faults (Fig. 2). Gravity data indicate that the depth to the Moho beneath the rise is about $23 \mathrm{~km}$, confirming its continental provenance with both in-situ Mesozoic granite and Oligocene-Miocene volcanic rocks dredged from its surface (Kaneoka, 1986; Tamaki, 1988).

The north to northwest-trending zone of en-echelon ridges and basins characterizing the eastern margin of the Japan Sea 
NW

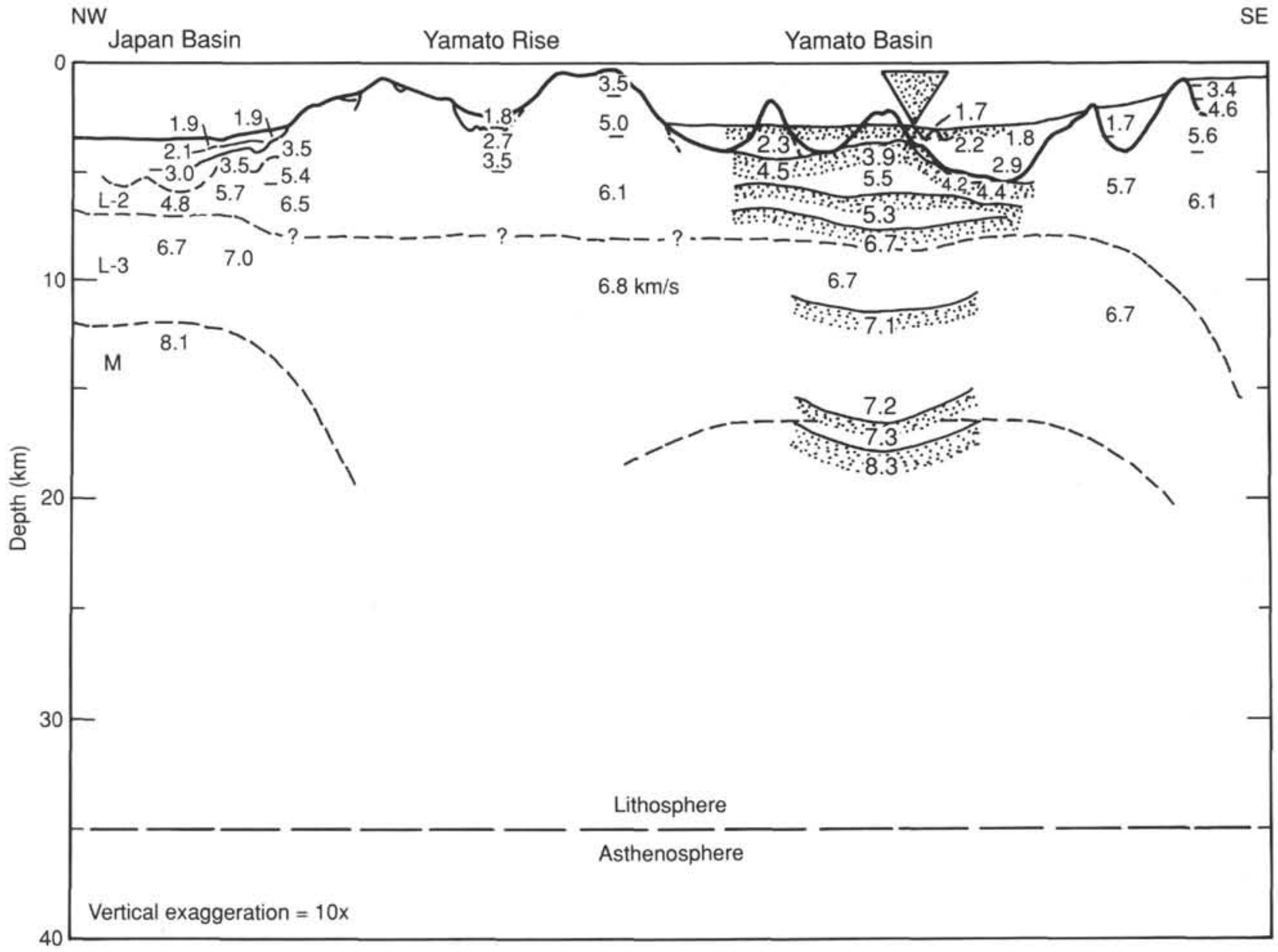

Figure 6. Crustal cross section through the Yamato Basin, Yamato Rise, and the Japan Basin. Figure modified from Ludwig et al. (1975), with stippled sections from Hirata et al. (1987) and Hirata et al. (in press), as presented by Tamaki et al. (1989).

forms the most distinctive physiographic-structural province in the sea (Tamaki, 1988; Tamaki, Pisciotto, Allan, et al., in press). The crustal shortening and compressive deformation that apparently initiated these structures in late PliocenePleistocene time is ongoing, as noted earlier (Minster and Jordan, 1978; Wesnousky et al., 1982), with large shallow focus earthquakes generally associated with the reverse faults common to this province (Tamaki and Honza, 1985; Figs. 2 and 4). The continental basement rocks underlying large areas of the eastern portion of this active tectonic belt on Honshu are well known from study of onshore and insular exposures and include Mesozoic granites as well as Paleozoic and Precambrian metamorphic rocks. Offshore, basement in this zone apparently includes both back-arc crust as well as isolated continental blocks (Fig. 5). Many of the major structures forming the borderland-style ridge and basin topography of this zone incorporate filled and deformed Neogene basins that were initially created in early Miocene time along the subsiding eastern margin of the proto-Japan Sea and within the rifting Japan Arc (Figs. 8, 11, and 12), as discussed and documented by Asano et al. (1975), Suzuki (1979), Sugi et al. (1983), and Iijima et al. (1988). Otsuki (1989) and Jolivet et al. (1989) also noted that Neogene translational faults associated with development of these early basins have been reactivated as a function of the late Pliocene-Quaternary compressive deformation affecting this zone.

\section{Kinematic Models of Japan Sea Formation}

Origins not related to plate tectonics that have been proposed for the Japan Sea include the concept of "oceanization," crustal thinning, and subsidence championed by Beloussov (1968) and the early Mesozoic stable geosynclinal origin envisioned by Gnibidenko (1979). However, the majority of models put forward over the past $20 \mathrm{yr}$ to explain the age and formation of the sea call for rifting of a continental arc and subsequent back-arc spreading as a function of the interactions among the four major crustal plates that converge in the Japan Sea region (Figs. 3 and 11). Most of these latter models favor the basic subduction process and related extensional/compressional stresses induced by motion of the upper plate in the collisional couple to foster back-arc spreading, as exemplified by (1) the Cretaceous KulaPacific Ridge subduction model of Uyeda and Miyashiro (1974) and (2) the regional Miocene trench roll-back model of Seno and Maruyama (1984). Variations of the general subduction model include the two-phase spreading history proposed by Hilde and Wageman (1973) and Ludwig et al. (1975), which calls for Cretaceous-early Tertiary opening of the Japan Basin and later Oligocene-Miocene spreading of the Yamato Basin.

Recent onshore paleomagnetic-radiometric studies of Miocene rocks on Honshu focused attention on the geometry of the back-arc spreading process. All of these studies present evidence supporting major rotations of the Japan Arc in concert 


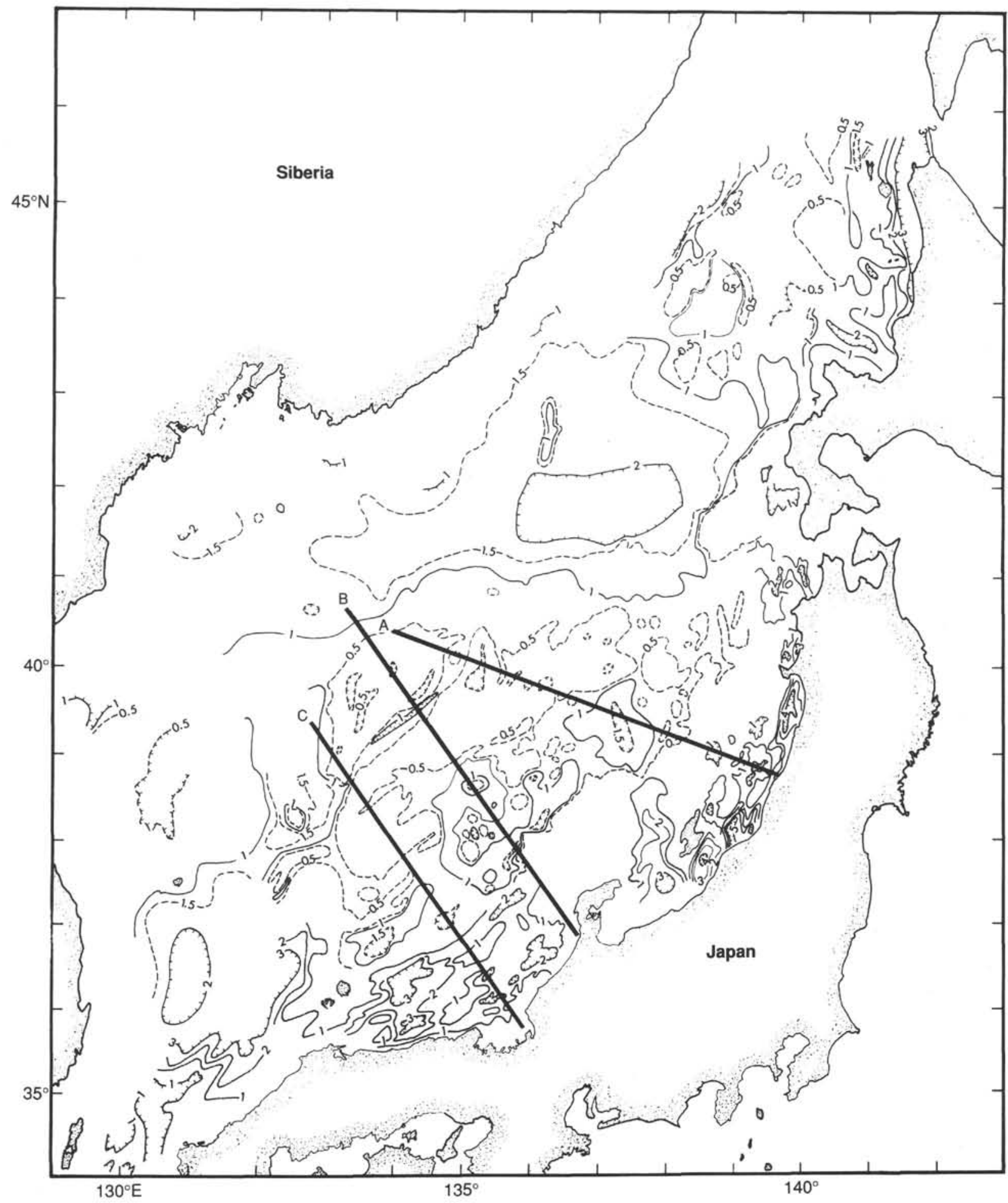

Figure 7. Sediment isopach map of the Japan Sea. Contours are in seconds of two-way acoustic traveltime. Lines A, B, and C show locations of seismic reflection profiles presented in Figure 8. Figure modified from Tamaki (1988), based on work by Ishiwada et al. (1984).

with rapid opening of the Japan Sea during early to middle Miocene time (e.g., Kawai, 1961; Yaskawa, 1975; Otofuji and Matsuda, 1983, 1987; Otofuji et al., 1985; Hayashida, 1986; Celaya and McCabe, 1987; Hirooka, 1987; Tosha and Hamano, 1988). Most recently, Tatsumi et al. (1989) invoked a model involving Oligocene-Miocene asthenospheric injection of mantle material, which they propose was ultimately responsible for Miocene back-arc extension and spreading of the sea between 21 and $14 \mathrm{Ma}$, following eastward migration of the northeast Japan Arc (Tohoku Arc) ca. 23 to 22 Ma.

In contrast to the basic subduction models noted above, Lallemand and Jolivet (1985), Jolivet (1986), and Jolivet et al. (1989) proposed models emphasizing the role of regional right-lateral intraplate and interplate shear along the western and eastern margins of the Japan Sea, which they think caused initial formation of the sea as a Miocene pull-apart basin. 

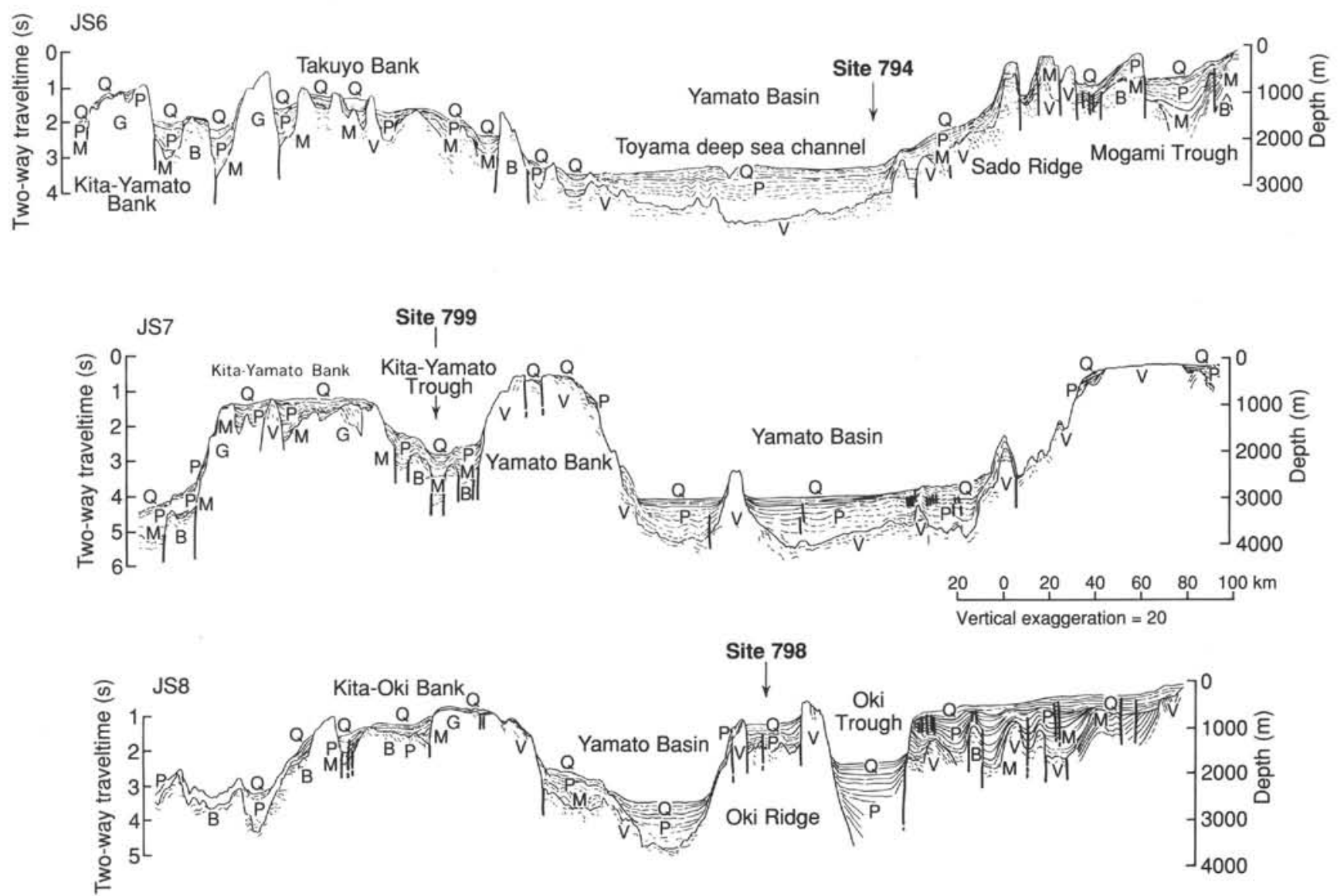

Figure 8. Line drawings and interpretations of selected single-channel seismic sections across the eastern Japan Sea. Approximate projected locations of Sites 794, 798, and 799 are shown for reference. Symbols represent the following rock units: $\mathrm{G}=$ granite, V = volcanic rock, B = unknown basement rock, $\mathrm{M}=$ Miocene sediments, $\mathrm{P}=$ Pliocene sediments, and $\mathrm{Q}=$ Quaternary sediments. Profiles from Tamaki (1988). See Figure 7 for locations.

An Oligocene-Miocene pull-apart and multi-axial spreading origin also was proposed by Kimura and Tamaki (1988) and Tamaki (1988), who related this process to regional readjustments of the Eurasian Plate and Amurian and Okhotsk microplates subsequent to collision of India and Eurasia (Fig. 3). This latter model invokes simultaneous back-arc spreading in the Japan Sea and the Kuril Basin in the Okthosk Sea through tectonically induced retreat of the two back-arc microplates, with the age of this event thought to occur sometime between 30 and $10 \mathrm{Ma}$ (Tamaki, 1986, 1988).

\section{Sedimentary Structure and Lithofacies}

Isopach maps of sediment thickness in the Japan Sea, based on two-way acoustic traveltime (Gnibidenko, 1979; Ishiwada et al., 1984; Tamaki, 1988), indicate that 1500 to 3000 $\mathrm{m}$ of sediment overlie acoustic basement in basinal areas of the sea (Figs. 7 and 8). More than $2.0 \mathrm{~s}$ of sediment are recorded in the Japan Basin and up to $1.6 \mathrm{~s}$ of sediment are present in the Yamato Basin.

Prior to ODP drilling, extensive single-channel reflection profiles, together with limited stratigraphic data from DSDP Leg 31 cores, piston cores, and dredges, indicated that similar stratigraphic sequences characterize most basinal areas of the sea, despite significant differences in sediment thickness (Karig, Ingle, et al., 1975; Ludwig et al., 1975; Honza, 1979; Tamaki et al., 1981; Tamaki, 1988). A typical basinal sequence includes (1) an upper, well-stratified and highly reflective unit composed of upper Pliocene to Holocene siliciclastic sands, silts, and/or clays overlying (2) a seismically transparent to moderately reflective unit of lower Pliocene to Miocene hemipelagic diatomaceous clays and other mud rocks (Figs. 7 and 8 ).

The Miocene-lower Pliocene hemipelagic blanket is ubiquitously draped over acoustic basement in most areas of the sea and is remarkably uniform in character. Drilling at DSDP Site 301 (Fig. 2) early confirmed that acoustically transparent subunits in the upper portions of these sediments represent Pliocene and upper Miocene diatomaceous oozes and muds (Karig, Ingle, et al., 1975). Alternatively, the unsampled older and seismically more reflective and stratified subunits above acoustic basement were thought to include diagenetically altered biosiliceous and calcareous hemipelagic sediments similar to and correlative with the porcellanites and hard siliceous shales of the Miocene Onnagawa and Funakawa formations of Honshu (Ingle, 1975b; Suzuki, 1979; Fig. 13). Initial ODP drilling at Site 794 confirmed this correlation (Tamaki, Pisciotto, Allan, et al., in press) and also demonstrated that the opal-A/opal-CT diagenetic boundary within these siliceous sediments is clearly expressed as a distinctive seismic interval, an association ultimately recognized at all six ODP sites drilled in the sea.

As noted above, highly reflective and stratified upper Pliocene and Quaternary terrigenous sediments commonly overlie the Miocene-Pliocene hemipelagic deposits in basinal areas of the sea. These younger units stand in sharp contrast to the relatively uniform hemipelagic deposits and display 


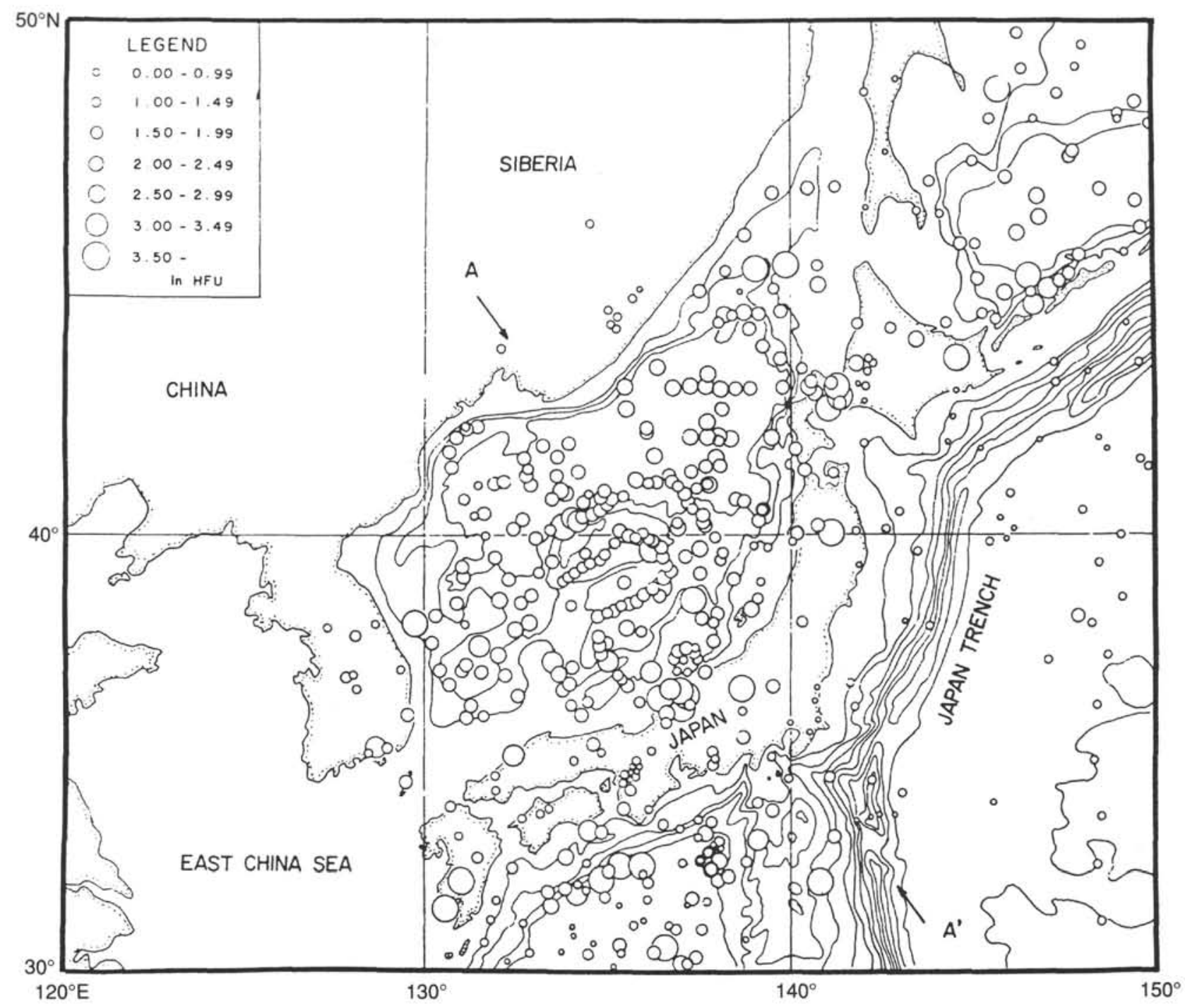

Figure 9. Heat flow values in the Japan Sea and adjacent areas of the Pacific Ocean and Philippine Sea. Circles indicate heat flow stations. Diameters of circles represent intensity of heat flow values. Figure from Watanabe et al. (1977).

large variations in thickness and composition, reflecting topographic control of sediment dispersal systems and the gravityflow process responsible for their rapid progradation across basin floors (Figs. 7 and 8 ). The Toyama Fan is the best studied of these systems (Bouma, 1975; Ludwig et al., 1975; Boggs, 1984; Tokuyama et al., 1987) and dominates the Quaternary depositional architecture of the northern Yamato Basin (Fig. 8). In fact, distal channels of this fan system distribute coarse sands well north and west into the adjacent Japan Basin, where they were penetrated during drilling at DSDP Sites 300 and 301 (Fig. 2).

In other basinal areas, away from major point sources of terrigenous sediment and channel complexes, slumping accounts for the initiation of Quaternary turbidite units, which are commonly interbedded and overlain by thick hemipelagic clays and silts of mixed nepheloid and mass-flow origins (Chough, 1984). Finally, piston cores have revealed the presence of a distinctive cyclic late Quaternary facies in basinal areas as well as on some topographic rises, which involves alternations of laminated organic-rich muds and bioturbated terrigenous silty clays thought to reflect major paleoceanographic changes in the Japan Sea as a result of eustatic and tectonic regulation of basin sills (Ujiie and Ichikura, 1973; Arai et al., 1981; Matoba, 1984). These unusual deposits were encountered in five of the six ODP sites drilled in the Japan $\mathrm{Sea}$, as discussed later in this chapter and detailed in specific site chapters.

In contrast to basinal areas, the well-stratified Pliocene to Holocene deposits are thin or absent over many topographic highs in the Japan Sea, with a typical ridge sequence consisting of a thin transparent layer of Pliocene-Quaternary diatomaceous clay unconformably overlying older, more reflective sedimentary units or acoustic basement. Other highs, such as the Oki Ridge (Fig. 8), contain small ridge top basins or depressions filled with a significant thickness of Quaternary and Neogene sediments. The highly variable thickness, composition, and ages of sediments on isolated highs reflect the individual structural and erosional histories of these features. For example, extensive dredges, piston cores, and DSDP cores from the Yamato Rise have confirmed the presence of in-situ Oligocene-Miocene volcaniclastic rocks, Miocene nonmarine sediments, and Miocene through Quaternary marine sediments, including diatomaceous mudstones and terrigenous gravels, sands, and muds (Karig, Ingle, et al., 1975; 


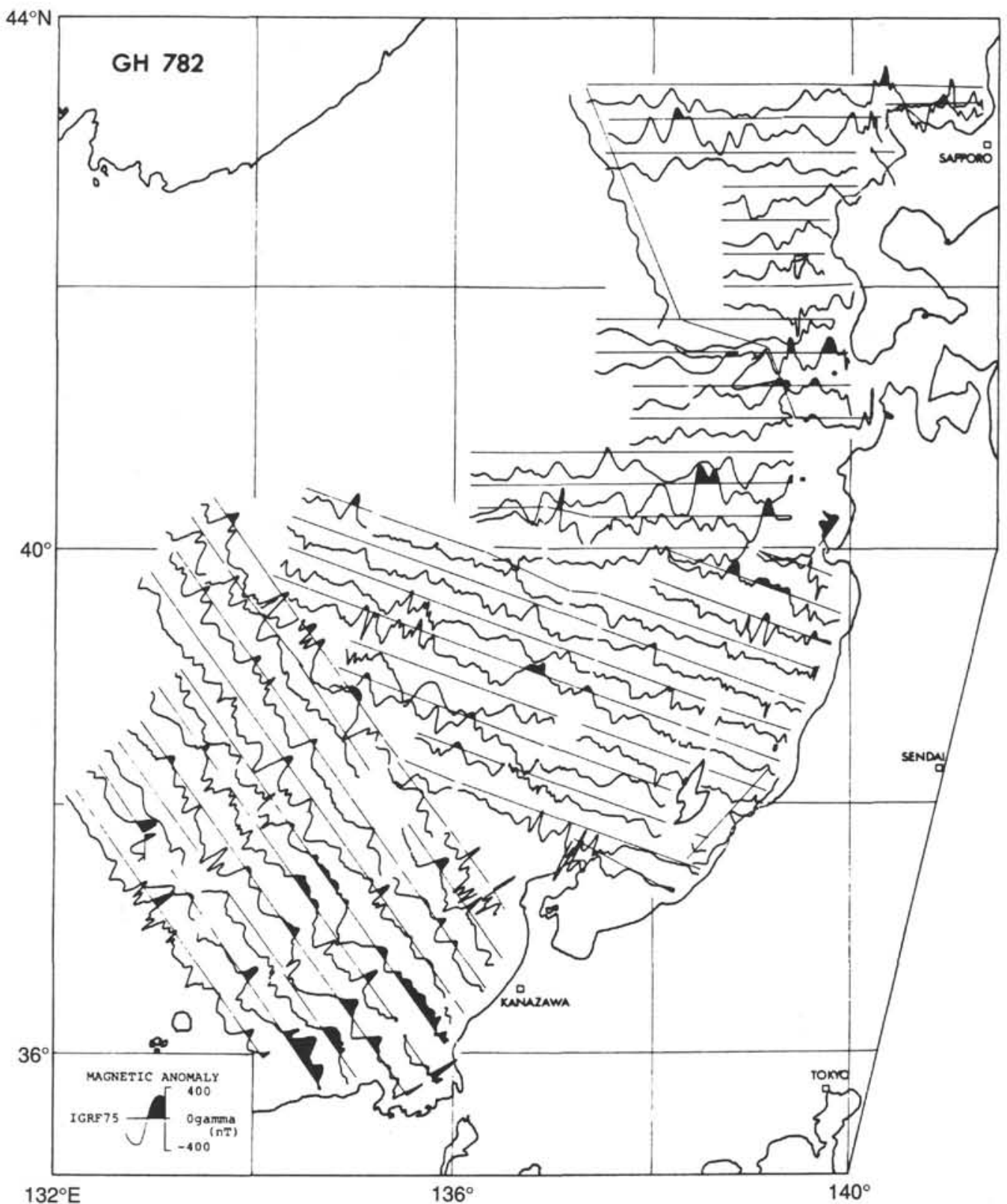

Figure 10. Profiles of magnetic anomalies in the eastern Japan Sea. Figure from Honza (1979).

Burckle and Akiba, 1977; Honza, 1979; Barash, 1986; Koizumi, 1988; Tamaki, 1988). These samples, together with reflection profiles (Fig. 8), reveal the presence of several faulted and eroded Neogene sedimentary sequences on the rise. Alternatively, structural lows within topographic highs can serve as protected sites of deposition, as illustrated by the Kita-Yamato Trough, which constitutes a failed-rift within the larger Yamato Rise. This feature has accumulated more than $1 \mathrm{~km}$ of Neogene sediment and constituted a prime drilling target during Leg 128.

\section{Onshore Sections and Regional Sedimentary History}

Additional pre-ODP insights regarding the depositional history of the Japan Sea were provided by onshore Neogene sequences present around the rim of the sea. Exposures of uplifted Neogene sub-basins are common along the eastern and southern margins of the Japan Sea from Sakhalin to the Korean Peninsula as a consequence of late Pliocene and
Quaternary deformation in these areas (Ingle, 1975b). Indeed, isopach maps (Fig. 7) illustrate that the thickest accumulations of sediment in the Japan Sea are not in the major deep basins, which stand largely unfilled (Fig. 1), but rather occur in the smaller, filled and deformed Neogene sub-basins that recently have been structurally incorporated into the western margins of Honshu and Hokkaido (Figs. 8 and 12). These latter basins contain up to $5000 \mathrm{~m}$ of Oligocene through Pleistocene sediments and have been extensively explored for petroleum (Suzuki, 1979), with the result that their stratigraphies are well established (Fig. 13).

All of the onshore Neogene basins display a similar sequence of lithofacies and so provide a broad outline of the Oligocene through Pleistocene depositional, paleoceanographic, and paleogeographic evolution of this region (Iijima et al., 1988). Indeed, the basic two-fold stratigraphic package of Miocene-Pliocene hemipelagic deposits and overlying Pliocene-Pleistocene terrigenous siliciclastics that constitutes 

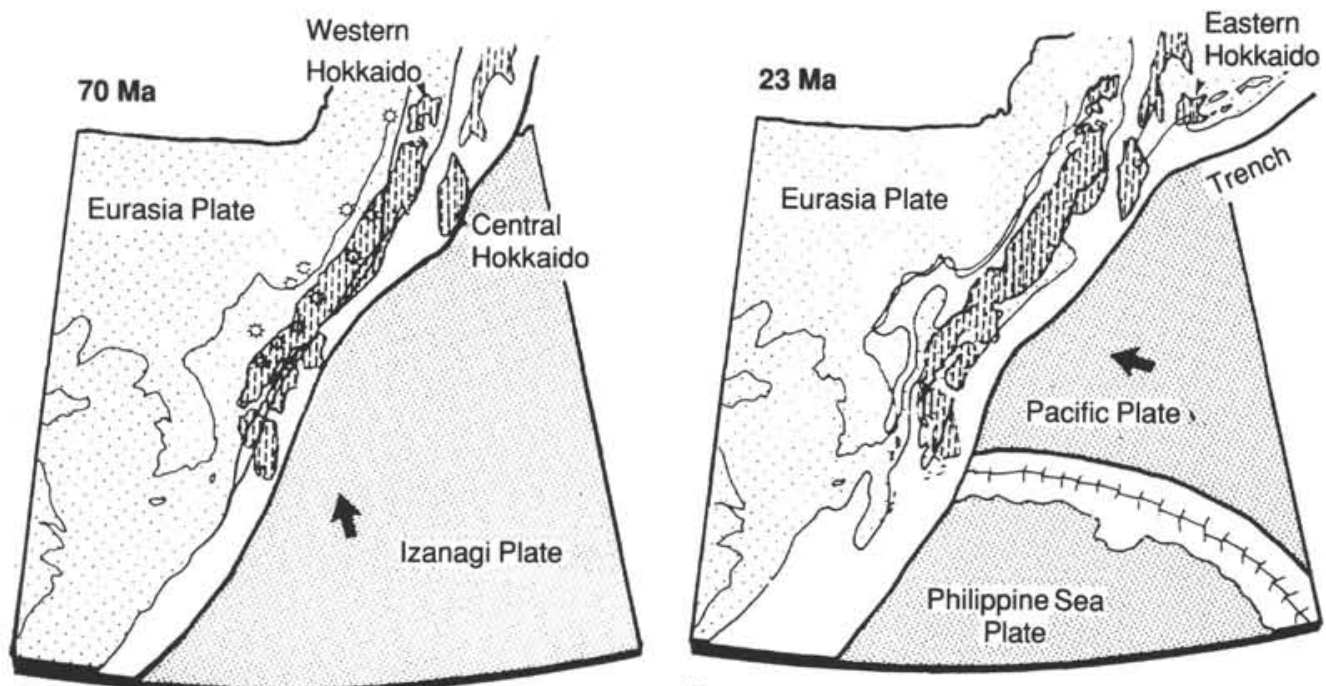

A

B
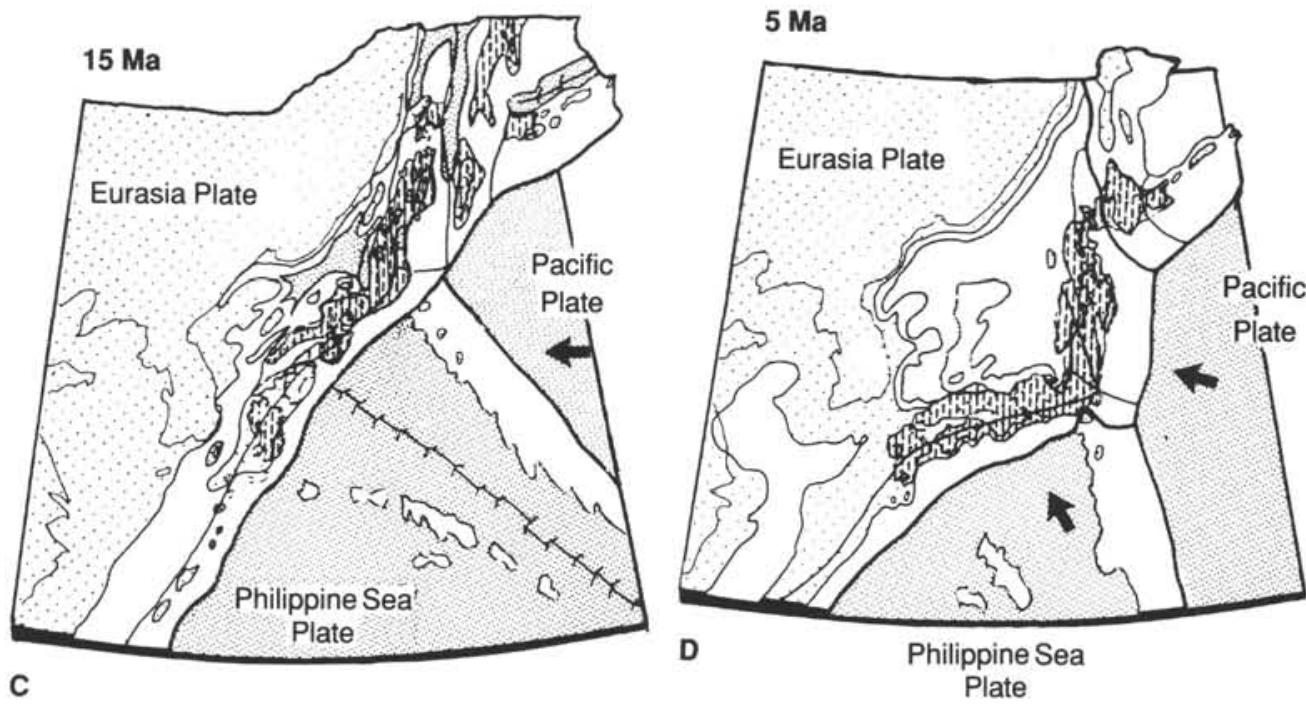

Deep sea

Jisip Japanese Island

Land

Co Caldera

Shallow sea and lakes

Figure 11. Schematic illustration of the development of the Japan arc and Japan Sea during late Cretaceous $(70 \mathrm{Ma})$, earliest Miocene (15 Ma), and earliest Pliocene (5 Ma) times. Paleomagnetic studies of Miocene volcanic rocks on Honshu suggest that the pronounced bending of the Japan arc, apparent in the $5 \mathrm{Ma}$ paleogeographic map, occurred ca. 17 through 15 Ma. Figure from Taira et al. (1989). See Figure 12 for schematic cross-sectional views of this evolution. 
Late Cretaceous to Paleogene

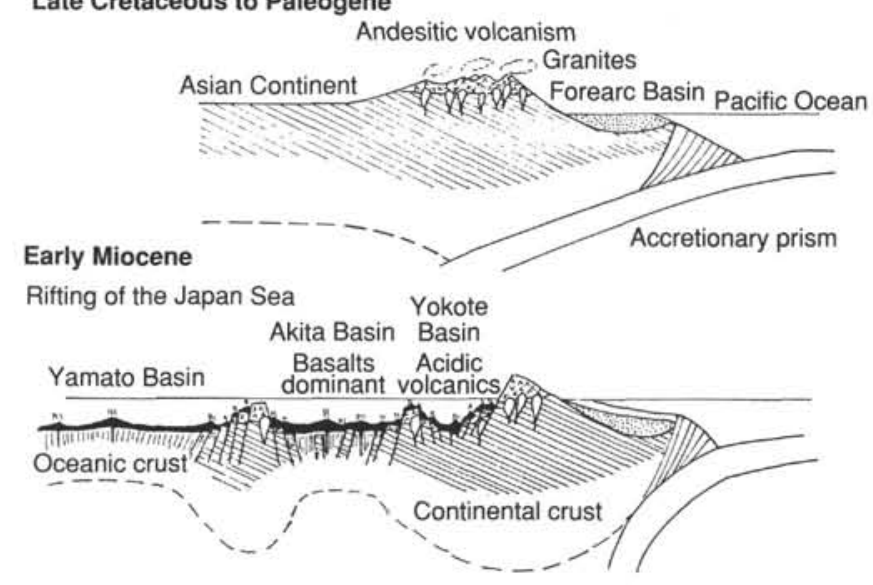

Pliocene to Present

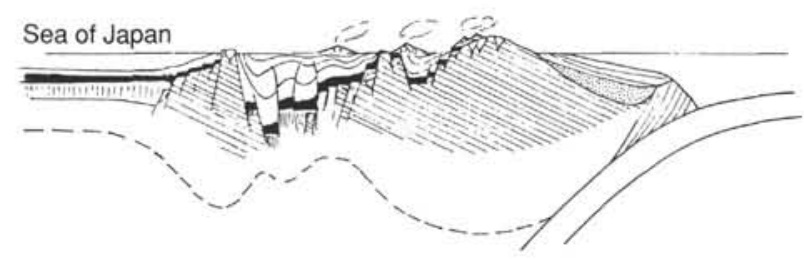

Figure 12. Schematic cross sections through the Japan arc and adjacent Japan Sea region during Late Cretaceous-Paleogene, early Miocene, and late Pliocene-Holocene time. The widespread "Green Tuff' volcaniclastic and volcanic deposits of Oligocene-early Miocene age are marked in solid black. Note that early Miocene rifting and subsidence of the Japan Sea involved formation of sub-basins (e.g., Akita and Yokote basins), which were subsequently filled, deformed, and exposed on Honshu as a result of late Miocene and Quaternary episodes of tectonic compression. Figure modified from Hoshi (1988).

the stratigraphic norm in the major offshore basins of the Japan Sea (Fig. 8) is clearly displayed and expanded in the thicker and more accessible onshore Neogene sequences (Figs. 13 and 14), emphasizing their value for interpreting the regional history of the sea as a whole.

The Oga Peninsula surface section in northwestern Honshu (Fig. 2) represents one of the best studied of the various onshore Neogene sequences (Takayasu and Matoba, 1976; Ikebe and Maiya, 1981) and when combined with subsurface data from wells in the adjacent Akita and Niigata basins (Tsuchi, 1981; Tsuchi et al., 1981) forms a reference section of special significance for Legs 127 and 128 drilling in the eastern Japan Sea (Fig. 13). Biostratigraphic, paleomagnetic, and radiometric age data from the Oga Peninsula section and other sequences along the western coast of Honshu provide a well constrained chronology for the Japan Sea as a whole (Asano et al., 1975; Tsuchi, 1981). In particular, diatom zonations offer an unusually reliable means of correlation and dating within the widespread diatomaceous sediments that characterize Holocene through Miocene deposition in the sea (Burckle and Opdyke, 1977; Koizumi, 1978, 1985), with radiolarians, silicoflagellates, calcareous nannoplankton, and planktonic foraminifers providing good control where present (e.g., Saito, 1963; Nakaseko and Sugano, 1973; Ling, 1975; Takayama, 1977; Sato et al., 1988; Kobayashi, 1985; and others). However, the unusually shallow carbonate compensation depth (CCD) in the Japan Sea, widespread diagenetic alteration of biosiliceous hemipelagic sediments, and the episodic dominance of low diversity cool water plankton, hamper the uniform application of any given biostratigraphic scheme.
The relative uniformity of lithofacies sequences present within the onshore Neogene basins (Fig. 14) together with biofacies evidence of variations in paleobathymetry, paleoenvironments, and paleoceanography (Asano et al., 1975; Ingle, 1975a, 1975b, 1981; Koizumi, 1983, 1988; Matoba, 1984; Chinzei, 1986a; Iijima et al., 1988; Fig. 13), recent advances in dating of these sequences (e.g., Tsuchi, 1981), and offshore evidence from the Japan Sea (Karig, Ingle, et al., 1975; Tamaki, 1988) collectively point to at least five major stages or phases in the Neogene sedimentary history of the region, as outlined next.

\section{Late Oligocene and Early Miocene}

This period encompasses the initial extension and rifting in the Japan Sea region and is marked by widespread silicic and intermediate volcanism and deposition of pyroclastic, volcaniclastic, nonmarine, and lacustrine sediments informally placed in the so-called "Green Tuff' units of Honshu and, more specifically, assigned to the Monzen Formation and correlative units exposed around the rim of the Japan Sea (Takayasu and Matoba, 1976; Kim, 1977; Ikebe and Maiya, 1981; Gladenkov, 1984; Fujioka, 1986; Iijima et al., 1988; Koizumi, 1988; Lee and Pouclet, 1988).

\section{Latest Early Miocene and Early Middle Miocene}

Continued deposition of nonmarine and volcaniclastic deposits of the later "Green Tuff"' units (Daijima Group) occurred during this period, along with the initial appearance of marine deposits. The earliest widespread deposition of marine sediments in the eastern Japan Sea region began in latest early Miocene through earliest middle Miocene time (ca. 18-16 $\mathrm{Ma}$ ), as recorded in onshore sections in Hokkaido and Honshu (Tsuchi, 1981). Significantly, these units include both deepwater and neritic deposits, as typified by the glauconitic Nishikurosawa Formation in the Oga Peninsula section (Fig. 13) and the correlative bathyal shales described from adjacent subsurface sequences (Ikebe and Maiya, 1981). These deposits clearly record an extremely rapid phase of basin subsidence.

\section{Late Middle and Late Miocene}

Basin subsidence accelerated during this period accompanied by widespread deposition of diatomaceous muds at bathyal depths under the alternating influence of oxic and suboxic water masses as exemplified by the Onnagawa and Funakawa formations (Fig. 13). These deposits reflect increasing rates of primary productivity in the Japan Sea as a function of climatic cooling and reductions in the flux of terrigenous sediments to deepening basinal areas, perhaps enhanced by global highstands of sea level.

\section{Late Miocene and Early Pliocene}

An increasing flux of terrigenous sediments during this period resulted in the dilution of diatomaceous hemipelagic deposits in some areas. The uplift of the northeastern Honshu Arc (Tohoku Arc) and its accompanying volcanism also occurred during this period and probably aided this condition (Fujioka, 1986). In addition, abrupt global eustatic decreases in sea level in late Miocene time may have isolated all or parts of the Japan Sea as a result of shallow basin sills (Burckle and Akiba, 1978; Barash, 1986) and initiated progradation of submarine fan systems into marginal sub-basins (lijima et al., 1988).

\section{Late Pliocene to Holocene}

Major progradation of submarine fan systems and deposition of coarse siliciclastics sequences in marginal basins 


\section{OGA PENINSULA, HONSHU, JAPAN}

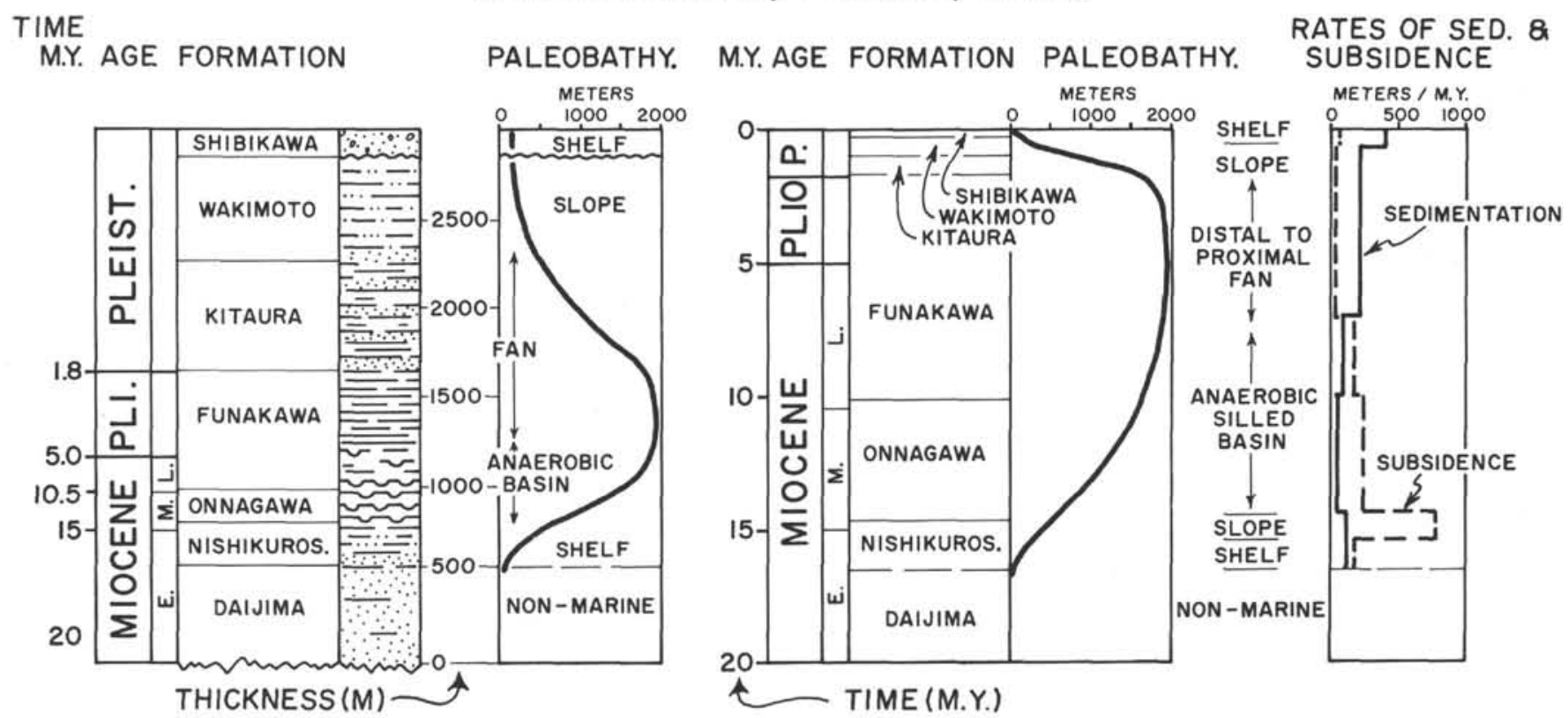

Figure 13. Stratigraphy, age, paleobathymetry, paleoenvironments, and depositional and subsidence histories of Neogene deposits exposed on the Oga Peninsula, northwestern Honshu (see Fig. 2 for location). Note that the Funakawa Formation of this illustration includes the Shinzan Diatomite of various authors (e.g., Tsuchi et al., 1981); this latter unit is sometimes included within the underlying Onnagawa Formation. Recent evidence indicates that the Pliocene/Pleistocene boundary is located in the lower portion of the Kitaura Formation, rather than at the base of this formation as shown above. Estimated rates of subsidence and sedimentation are uncorrected for compaction. Figure from Ingle (1981).

occurred during this period and continues today in nearshore basins. Remarkably rapid filling of basins occurred along the eastern margin of the sea because of Quaternary compressive deformation of this region, with uppermost Pliocene and Pleistocene turbidite deposits commonly making up more than one-half of all Neogene sediments filling many of these basins, as typified by the Kitaura and Wakimoto formations in the Oga Peninsula section (Fig. 13). Quaternary eustatic variations of sea level also controlled depositional patterns during this period, both in marginal sub-basins and in the major basins of the sea (Iijima et al., 1988). In addition, highstands and lowstands of sea level, in concert with tectonically emplaced shallow sills, apparently caused restricted or complete isolation of the sea from the Pacific Ocean during this period, dictating extremes in oceanographic conditions. Distinctive cyclic deposits marked by organic-rich units of unusual geochemistry suggest that the sea may have experienced dramatic oscillations between a near-anoxic state and a hyperventilated oxic state, exemplified by the modern sea (Hidaka, 1966; Miyake et al., 1968; Ujiie and Ichikura, 1973; Ingle, 1975a; Ichikura and Ujiie, 1976; Arai et al., 1981; Oba, 1983b; Matoba, 1984).

\section{SCIENTIFIC OBJECTIVES}

The principal objectives of Leg 128 were (1) to obtain a master Miocene to Holocene, paleoceanographic reference section, (2) to detail the depositional history of a failed back-arc rift as an ideal setting for mineralization of volcanogenic massive sulfides, and (3) to conduct two large-scale, downhole, multiship geophysical experiments at a basement site in the Yamato Basin for analyzing the structure of the deep crust and upper mantle beneath the Japan Sea region. Two additional objectives were later added to the Leg 128 agenda as a result of special opportunities and circumstances. These included a program of sterile microbiological sampling of organic-rich sediments to establish the role of bacteria in diagenesis of marine sediments and extended coring of volcanic rocks below acoustic basement in the Yamato Basin.

The basic strategy employed for ODP drilling in the Japan Sea called for scientists of Leg 127 to drill three basinal sites in the Yamato and northern Japan basins (Sites 794, 795, and 797) and a fourth site on Okushiri Ridge in the eastern tectonic zone of the sea (Site 796) with the principal aims of (1) sampling acoustic basement beneath these two major basins, (2) analyzing the depositional histories of the basins, and (3) dating the initiation of deformation along the eastern margin of the sea. Scientists of Leg 128 were to drill two additional sites located on topographic highs (Sites 798 and 799) to meet the stratigraphic objectives noted above and to re-occupy a third site previously drilled and prepared during Leg 127 (Site 794) for the planned geophysical experiments (Fig. 2 and Table 1).

Site 798 was located in a small isolated basin atop Oki Ridge, selected as an ideal site for recovery of the paleoceanographic reference section (Fig. 2). Site 799 was located in the southern Kita-Yamato Trough within the larger Yamato Rise, a structural and depositional setting thought to be directly analogous to the failed-rift environments of the Kuroko massive sulfide deposits of Honshu. Finally, our plan was that we would return to Site 794 in the northern Yamato Basin, initially drilled during Leg 127, for deploying a borehole seismometer and for conducting the two large-scale, multiship geophysical experiments that involved seismic analysis and an oblique electrical resistivity experiment utilizing a dedicated hole, which was to be drilled at this site.

\section{Paleoceanographic and Depositional History}

Drilling at all six ODP sites in the Japan Sea was expected to yield important new microfaunal, isotopic, lithologic, and geochemical data bearing on the paleoceanographic evolution of the sea. However, Site 798 was the only site dedicated solely to recovery of a paleoceanographic reference section. The small ridge-top basin on Oki Ridge selected for this site 

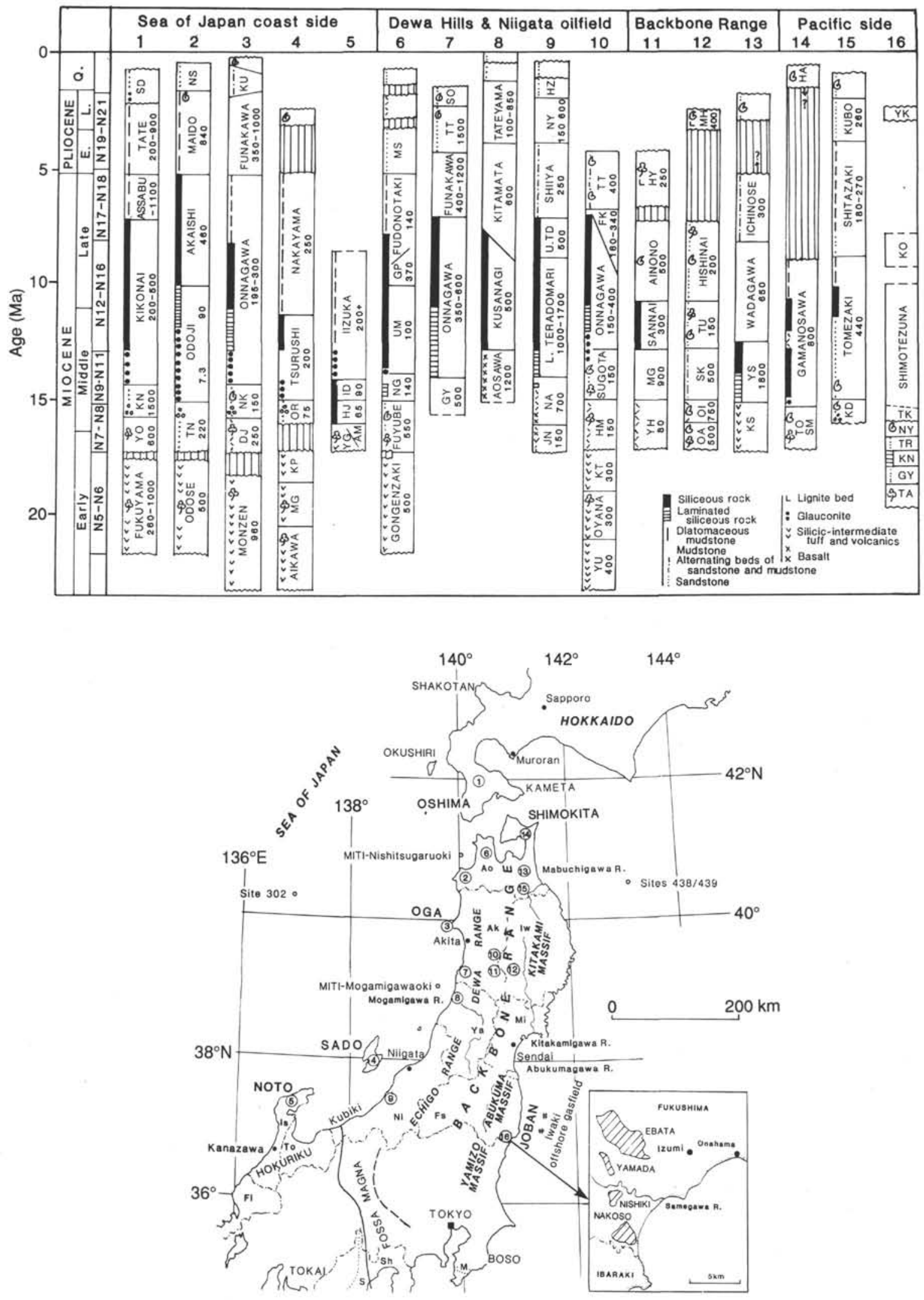

Figure 14. Summary stratigraphic columns of Neogene surface and subsurface sequences in northern Honshu, Japan. Figure from Iijima et al. (1988). 
(Figs. 2 and 8) was thought to lie well above the shallow CCD present in the Japan Sea and to be filled exclusively with Miocene to Holocene pelagic and hemipelagic sediments as a result of its isolated position above the floor of the Yamato Basin and associated coarse clastic deposits (Fig. 8).

Site 799 in the Kita-Yamato Trough was also viewed as a potentially rich source of paleoceanographic data for studying the central Japan Sea and offered an expanded Miocene through Holocene depositional record because of the unusual thickness (about $1200-1300 \mathrm{~m}$ ) of sediments stored in the trough (Fig. 8). Reports and interpretations of Miocene nonmarine and phosphatic marine sediments on the flanks of the Yamato Rise (Burckle and Akiba, 1977; Barash, 1986; Koizuimi, 1988) suggested that the Kita-Yamato Trough sequence might also yield details of paleoenvironmental conditions specific to the rise area, perhaps including the presence of a lake during emergent phases of its evolution and upwelling that was induced by its topographic prominence in the $\mathrm{Mi}$ ocene sea.

\section{Modern Oceanographic Setting}

The modern Japan Sea provides an especially revealing example of how the oceanographic behavior of a marginal sea can be tightly controlled by the tectonic and eustatic manipulation of its gateways with the adjacent open ocean. The modern Japan Sea also serves as a useful model for understanding its Neogene paleoceanographic history.

Despite water depths exceeding $3000 \mathrm{~m}$, most of the water filling the Japan Sea is completely isolated from the deep and intermediate water masses of the adjacent Pacific Ocean by four extremely shallow sills, which average less than $60 \mathrm{~m}$ deep (Fig. 1). The topographic isolation of the sea, in combination with the severe winter climate in its northern reaches (including the formation of sea ice), produces an extraordinarily cold and highly oxygenated water mass that contrasts sharply with the thermally stratified and suboxic waters of the adjacent open Pacific Ocean (Fig. 15). In fact, the Japan Sea contains the most homogeneous and well-mixed water of any marginal sea in the world (Worthington, 1981), which is viewed as prime evidence that all of the water filling the sea has been derived exclusively from its surface water (Fig. 16).

Although warm, high-salinity surface water enters the sea from the south as a branch of the Kuroshio Current known as the Tsushima Current, it is the cold, low-salinity surface water produced internally within the northern part of the sea that is primarily responsible for maintaining the hyper-ventilated and highly oxic state of the modern sea (Figs. 15, 16, and 17). This latter water, termed the Liman Current, travels south and ultimately sinks because of its high density, perhaps aided by mixing and caballing at the front formed with the Tsushima water (Fig. 17). The convective circulation induced by these processes constantly maintains the cold, well-oxygenated water mass characterizing the modern sea at all depths below $300 \mathrm{~m}$ (Fig. 15).

These conditions have significant importance for the interpretation of modern and ancient sedimentary facies in the Japan Sea in that they are thought to be responsible for (1) the usually shallow CCD in the sea (about $1500-2000 \mathrm{~m}$ ), (2) the presence of carbonate-depleted, deep-sea "red clays" at shallow depths, and (3) the low organic carbon values in surface sediments of the sea despite the relatively high productivity its surface waters (Niino et al., 1969; Ujiie and Ichikura, 1973).

\section{Neogene Paleoceanography}

The shallow sills or straits controlling the modern oceanographic state of the Japan Sea were tectonically emplaced as a
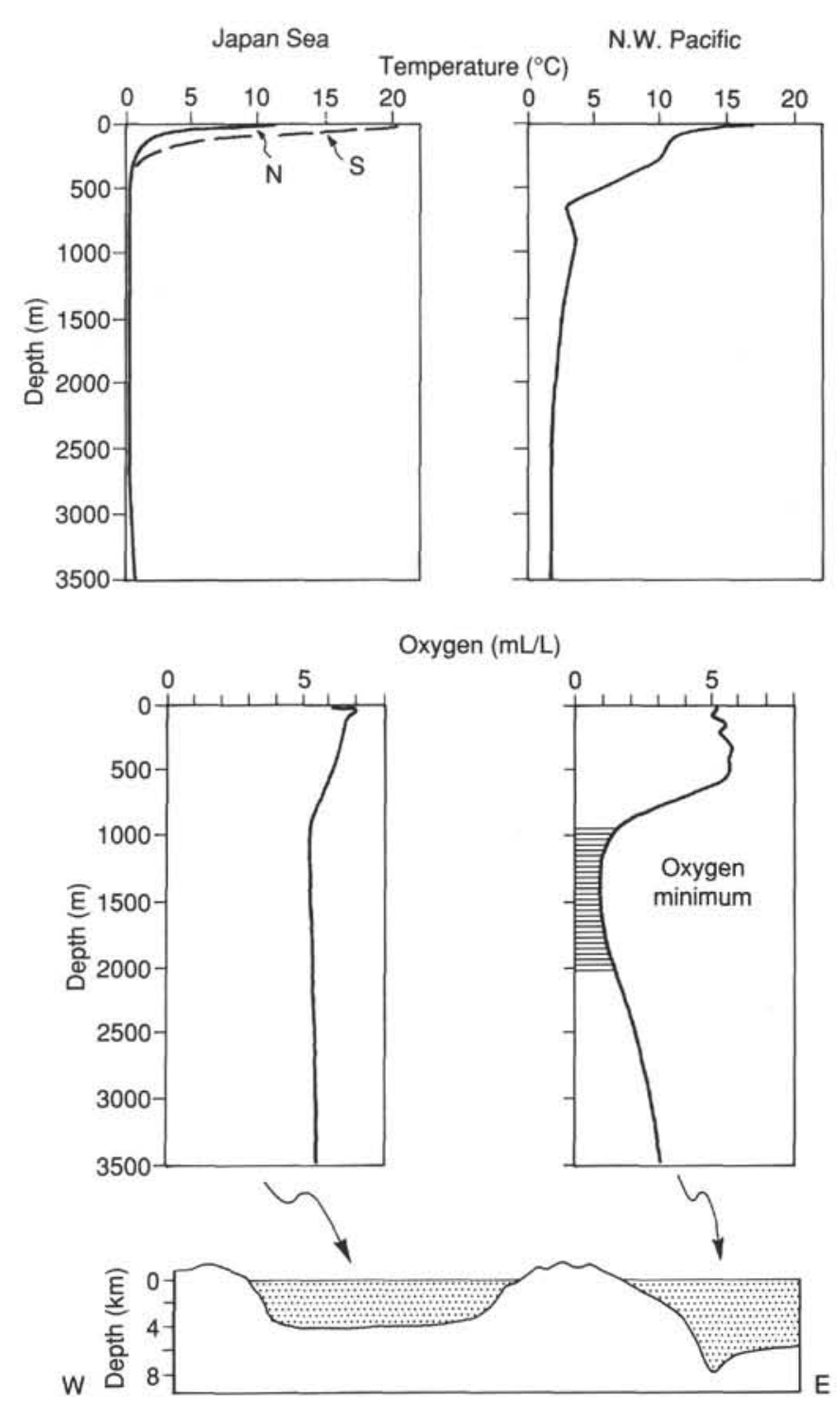

Figure 15. Distribution of temperature and dissolved oxygen in the Japan Sea and the adjacent Pacific Ocean. Figure modified from Matoba (1984).

result of Quaternary deformation along the eastern margin of the sea and subsequent modification by erosional and depositional events associated with eustatic rises and falls of sea level. In short, they are geologically transient features. Indeed, there is multiple evidence that both deep and intermediate waters of the Pacific entered the sea during earlier phases of its history, when deep passages and basins were open between the tectonically evolving islands forming the Japan Arc (e.g., Chinzei, 1978, 1986a; Figs. 18 and 19). Alternatively, Ujiie and Ichikura (1973), Ingle (1975a), Arai et al. (1981), Oba (1983b), and Matoba (1984) emphasized the likelihood that eustatically lowered sea levels during Quaternary glacial maxima caused complete isolation of the Japan Sea, resulting in stagnant reducing conditions in the sea that are manifested by distinct intervals of organic-rich sediment reported from Quaternary cores (e.g., Miyake et al., 1968; Ujiie and Ichikura, 1973; Arai et al., 1981). Similar but much earlier episodes of eustatic isolation of the sea have been suggested, based on data obtained from Miocene cores from the Yamato Rise (Burckle and Akiba, 1977). 


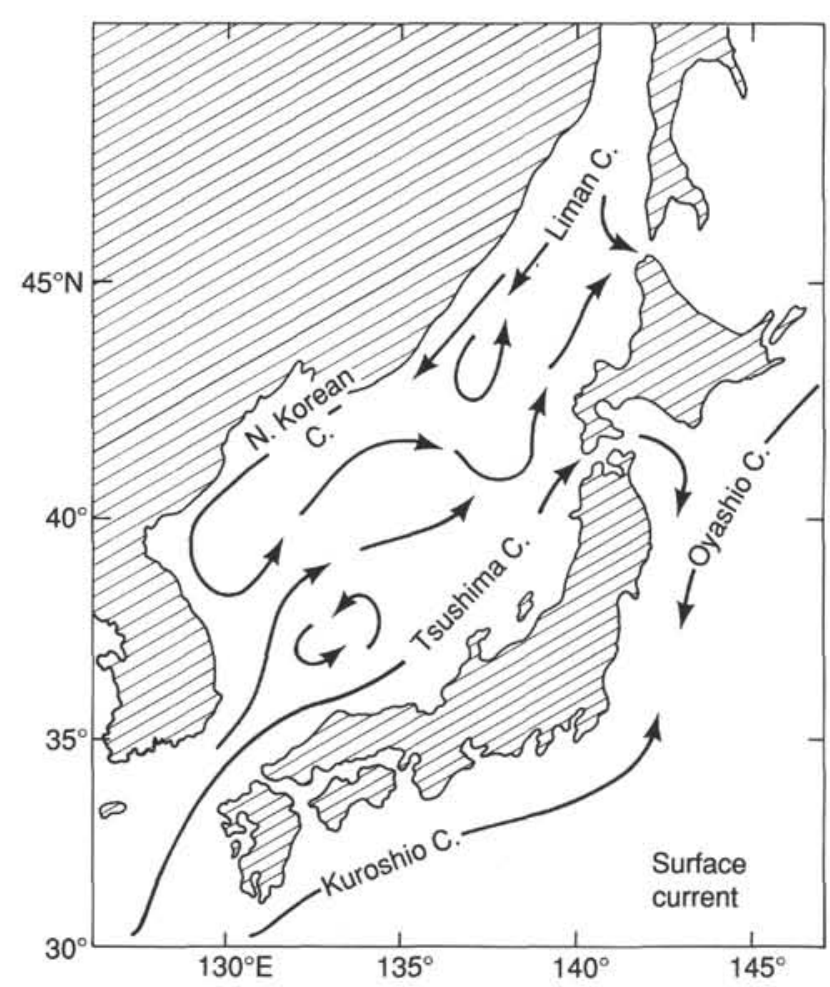

Figure 16. Principal surface currents in the Japan Sea and adjacent Pacific Ocean. Note that the Tsushima Current is a branch of the Kuroshio Current. The Liman and North Korean currents represent cold surface water generated within the northwestern Japan Sea. Figure from Ingle (1975a).

Lithofacies and faunal patterns in both onshore and offshore sequences demonstrate that the Neogene Japan Sea experienced wide extremes of temperature, productivity, and circulation as a result of tectonically and eustatically controlled changes in basin geometry, gateways, and the local impact of global and regional paleoclimatic and paleoceanographic events (e.g., Matoba, 1984; Fig. 19). For example, the widespread occurrence of Miocene diatomaceous sediments within the sea calls for enhanced primary productivity with laminated organic-rich units within these sequences, marking near-anoxic phases in the evolution of intermediate and bottom water, possibly involving expanded oxygen minima (Figs. 13,14 , and 19). Similarly, temporal and spatial variations in temperature-sensitive calcareous and siliceous plankton and molluscan fossils in cores and surface sections point to major variations in the source, character, and vigor of surface circulation in the sea (e.g., Saito, 1963; Asano et al., 1975; Ujiie and Ichikura, 1973; Ingle, 1975a; Ichikura and Ujiie, 1976; Koizumi, 1978, 1983, 1989; Oba, 1983b; Matoba, 1984; Chinzei, 1986b; Fig. 19).

\section{Evolution of a Failed-Rift and Back-Arc Metallogeny}

The Kita-Yamato Trough topographically splits the larger Yamato Rise in half (Fig. 2). All available geologic, structural, and geophysical data indicate that this narrow sediment-filled graben represents a failed-rift that formed within a continental fragment that was isolated during early Miocene spreading in the Japan Sea (Tamaki, 1988; Figs. 2, 8, and 20). Site 799 was located in the southern part of the Kita-Yamato Trough, with the primary objective of detailing the depositional history of the trough as an ideal or typical setting for volcanogenic massive sulfide mineralization in a rifted continental-arc setting. This site represents the first DSDP-IPOD-ODP site selected primarily to test concepts of deep sea metallogeny. As noted earlier, the thick sediment column in the KitaYamato Trough was also expected to yield an expanded Miocene to Holocene paleoceanographic record, perhaps including well-developed anoxic-suboxic facies as a result of the silled character of the trough.

Ohmoto and Skinner (1983) noted that all of the known volcanogenic massive sulfide deposits in the world are encased in volcanic rocks and are accompanied by evidence of submarine extrusion in almost every instance. These deposits are principal sources of copper, lead, zinc, silver, and gold, and range from Archean to Holocene in age, with modern examples including the much reported black-smoker deposits of the East Pacific Rise (Francheteau et al., 1979) and the massive sulfides recently discovered in the Okinawa Trough (Halbach et al., 1989). The Miocene Kuroko deposits of northern Honshu (Fig. 21) represent one of the best known

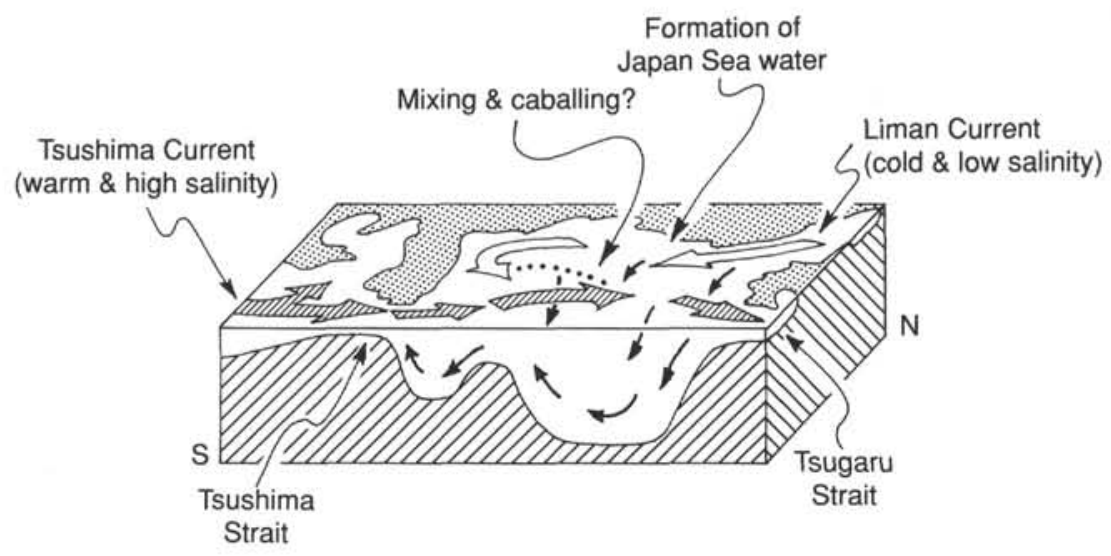

Figure 17. Schematic illustration of shallow and deep circulation in the modern Japan Sea. Note that formation of deep and intermediate water through mixing and caballing of Tsushima and Liman surface water is speculative. Alternatively, the descent of cold high-density water produced in the northern Japan Sea in winter is an established source of deep water and assumed to be responsible for the thorough ventilation and fully oxic character of Japan Sea water at all depths (Hidaka, 1966). Figure modified in part from Oba (1983a). 


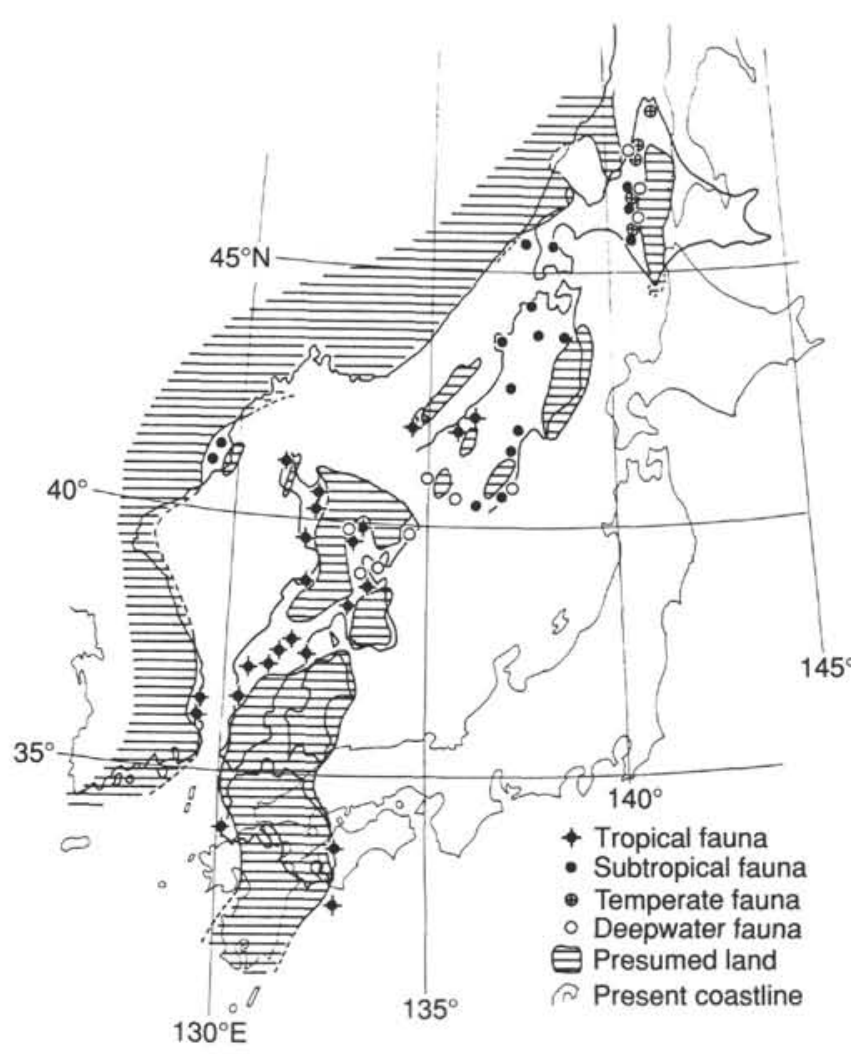

Figure 18. Early middle Miocene paleogeography of the Japanese Islands and the Japan Sea prior to proposed clockwise rotation of southwestern Japan and counterclockwise rotation of northern Japan ca. 16 to $15 \mathrm{Ma}$ and the distribution of distinctive molluscan faunas. Figure from Chinzei (1986b).

examples of this type of massive sulfide mineralization due in large measure to a recent study detailing their evolution and character (Ohmoto and Skinner, 1983). The evidence amassed by this joint U.S.-Japan-Canada cooperative research endeavor indicates that the Kuroko ores were formed as precipitates from hot hydrothermal fluids that issued from vents located in a series of deep bathyal $(>2000 \mathrm{~m})$ sedimented failed-rifts, which formed during the early Miocene rifting of the Japan Arc and eastern proto-Japan Sea (Figs. 12 and 21). This geologic, tectonic, and oceanographic context is thought to be directly analogous to that represented by the KitaYamato Trough (Fig. 20). However, the advantage of the Site 799 sequence lies in the fact that it is structurally intact and presumably contains a complete history of the trough, as opposed to the onshore Kuroko sequences that were dismembered during the late Miocene uplift of the northern Japan Arc (Fig. 22).

Interestingly, the time of ore formation so far established for individual Kuroko deposits varies between 16 and $13 \mathrm{Ma}$ (Tanimura et al., 1983; Fig. 22), which slightly post-dates the initial rapid subsidence of many sub-basins known in this region (Figs. 12, 13, and 14).

We thought our chances of actually encountering a massive sulfide or shale-hosted ore body at Site 799 were extremely remote, even if present, because of the low probability of hitting such a small feature. Rather, our primary aims were to further the understanding of potentially metalliferous back-arc environments and to obtain data that would permit us to make detailed comparisons with similar environments now exposed on Honshu and elsewhere.
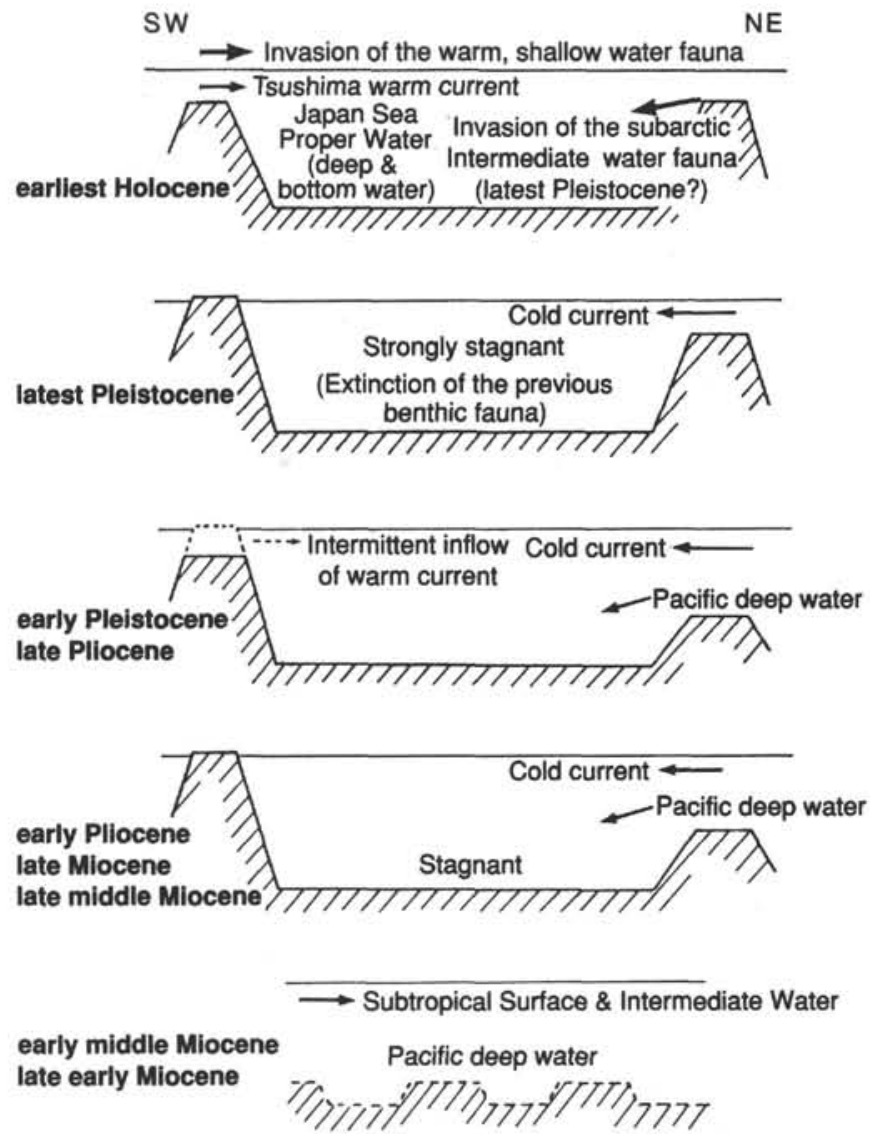

Figure 19. Schematic east-west profiles through the Japan Sea illustrating proposed variations in paleoceanographic-hydrographic conditions in the sea from early Miocene through Holocene time, based primarily on analysis of foraminiferal biofacies by Matoba (1984). Note the importance of tectonic and eustatic control of basin sills in regulation of both surface and deep-water circulation and provenance. Figure from Matoba (1984).

\section{Geophysical Experiments}

A truly unique aspect of the Leg 128 goals and operations was our plan to conduct two large-scale geophysical experiments at Site 794 in the northern Yamato Basin with the objective of obtaining new insights into the structure and character of the deep crust and upper mantle beneath the Japan Sea region. Both experiments required the use of two supporting vessels from the University of Tokyo Ocean Research Institute that were scheduled to meet the JOIDES Resolution at Site 794. One experiment involved emplacement of a newly developed broad-band digital seismometer in basement rock beneath Site 794 using a fully cased hole that had previously been drilled and prepared during Leg 127 . The second experiment involved large-scale oblique electrical resistivity measurements using a supporting ship to inject current to the water column and measurements using a series of electrodes deployed in a dedicated hole at Site 794.

The borehole seismometer to be used at Site 794 was designed specifically for this experiment and consists of a three-component system with an 18-bit range capable of capturing and recording a wide spectrum of seismic waves/ events ranging from those produced by local microearthquakes to surface waves produced by major earthquakes. After installation of the seismometer in a cased hole, a real-time controlled-source experiment was to be performed 


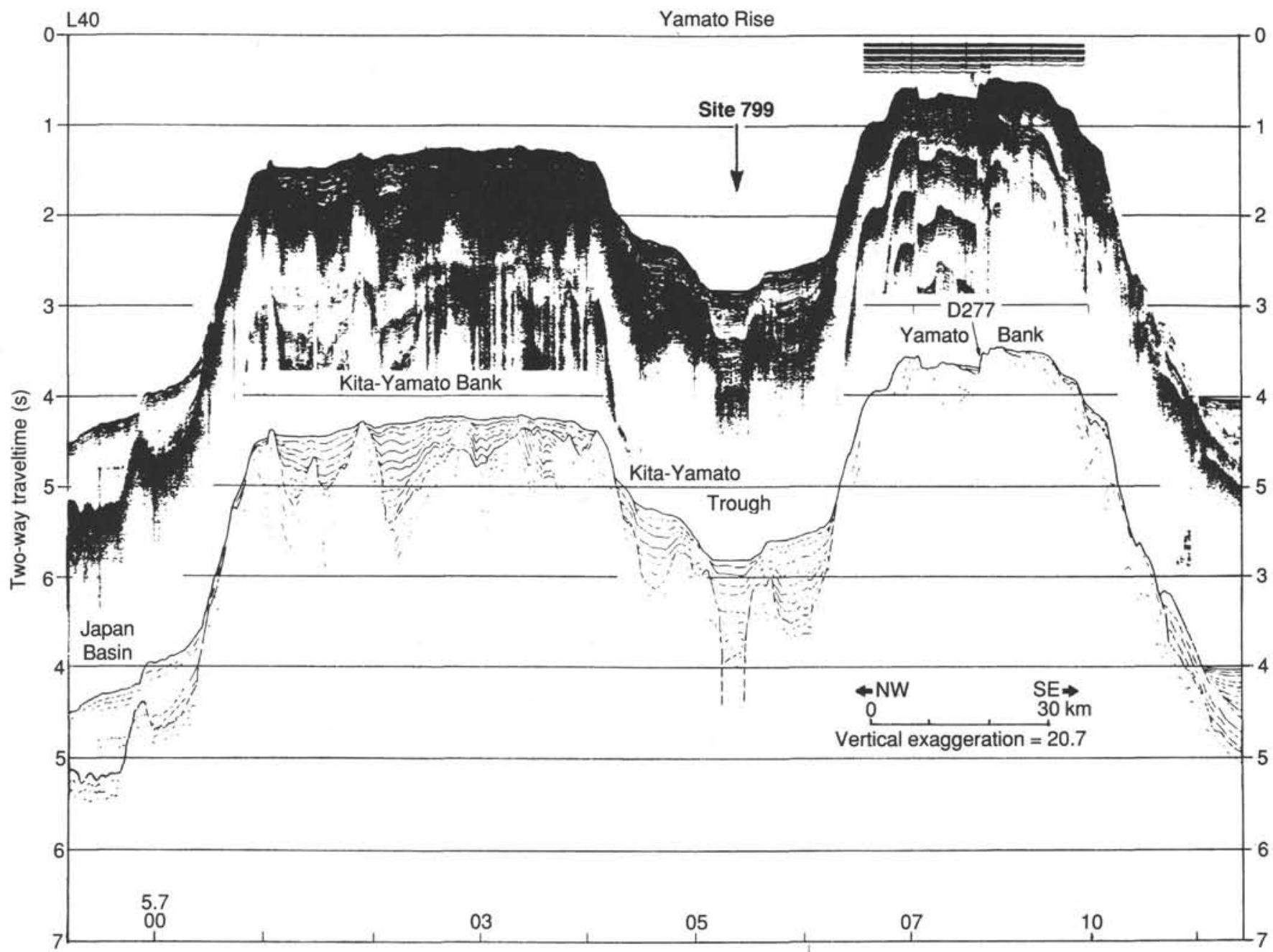

Figure 20. Single-channel seismic reflection profile and line drawing across the Kita-Yamato Trough and the larger Yamato Rise. Figure from Tamaki (1988).

both to test the instrument and to obtain data about local crustal structure. For this purpose, air guns and ocean-bottom seismometers were to be deployed by one of the supporting vessels. Next, long-term observations using the borehole seismometer were to be initiated by deploying a digital recording unit and power supply along with a retrieval device on the seafloor. Accumulation of data from natural earthquakes by this ocean-bottom and downhole instrument array will ultimately be used to establish the laterally heterogeneous crust/ upper mantle structure beneath the Japan Sea region. Combining seismic data obtained from our ocean-based station together with data from onshore stations should provide a more complete picture of the deep structure beneath the entire back-arc/arc/trench trench system than heretofore available.

After completing the seismic experiments, we planned to drill an uncased hole to $400 \mathrm{mbsf}$ at Site 794 to be used for the oblique electrical resistivity experiment. A series of electrodes were to then be placed in the hole from the JOIDES Resolution and subsequently used to measure real-time variations in the electrical field as a supporting vessel injected electrical current into the water column at various distances from the hole.

Although measurements of natural electromagnetic disturbances allow for determination of resistivity down to about $300 \mathrm{~km}$, the presence of a deep water column restricts resistivity determinations at shallow depths. Available measurements of electromagnetic structure in and around the Japanese Islands have yielded data inconsistent with the high heat flow, young crustal age, and thin lithosphere present in this area (Figs. 4 and 6). Data anticipated from the Site 794 experiment should reveal the resistivity structure beneath this site to a depth of $10 \mathrm{~km}$ and aid in the interpretation of earlier observations. Because variations in electrical resistivity are sensitive indicators of temperature changes in the crust and mantle, they can be used to infer the presence of partial melts or fluids at depth.

Similar electrical resistivity experiments have been previously performed in DSDP holes (Francis, 1982; Von Herzen et al., 1983; Becker, 1985); however, our experiment represents a novel two-vessel approach.

\section{Acoustic Basement}

As noted above, Site 794 in the northern Yamato Basin was selected to be occupied twice during Legs 127 and 128 drilling in the Japan Sea. The primary drilling objective at this site was penetration and sampling of rocks representing acoustic basement near the important crustal juncture between the Yamato and Japan basins (Fig. 2). Leg 127 scientists were to perform this task and were also responsible for preparing a cased hole in which a seismometer would be deployed during re-occupa- 


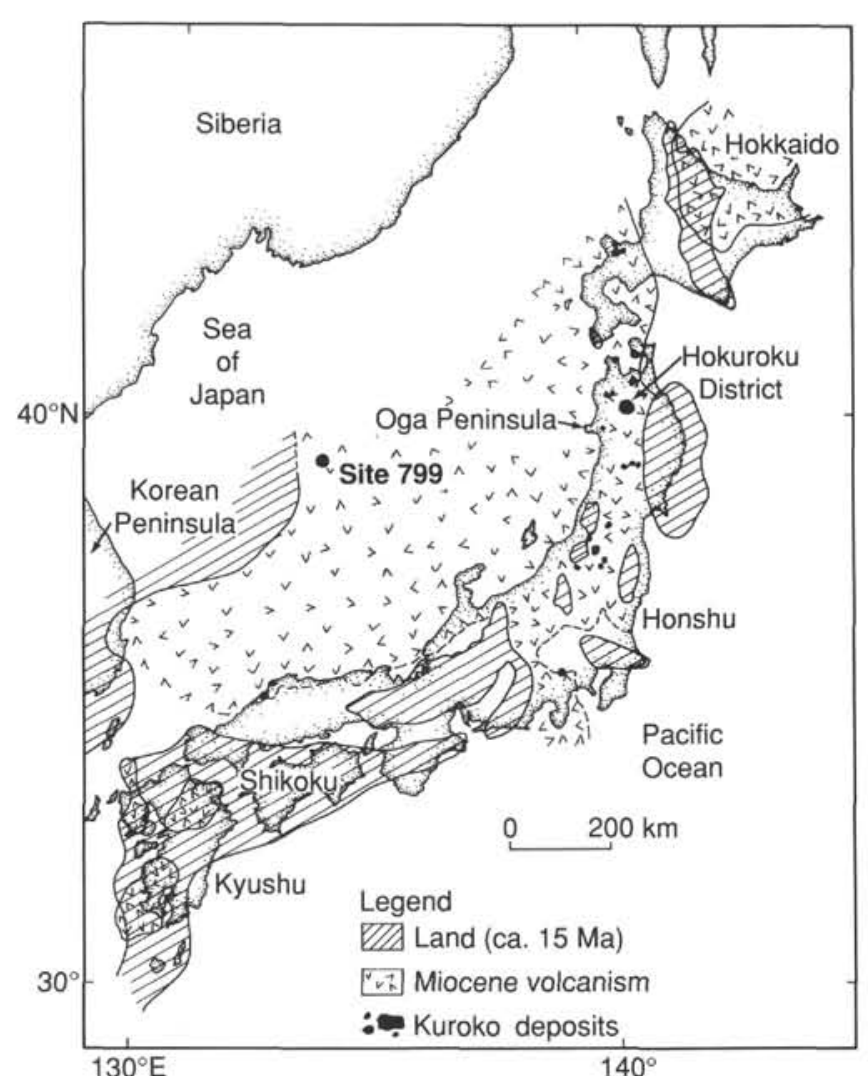

Figure 21. Location of Miocene Kuroko volcanogenic massive sulfide deposits in Japan and schematic middle Miocene paleogeography of the Japanese Islands and adjacent Japan Sea (not restored in light of paleomagnetic evidence of early middle Miocene rotation of the Japan Arc). The Hokuroko mining district represents the largest and best known of these deposits (Ohmoto and Skinner, 1983). Figure modified from Ohmoto (1983).

tion of Site 794 by Leg 128 scientists. In turn, Leg 128 objectives at this site were to conduct the two geophysical experiments described above, including the drilling of a single uncased dedicated hole to be used for electrical resistivity measurements.

Leg 127 scientists successfully met their objectives at Site 794 and recovered an excellent 543-m-thick, Miocene to Holocene, sedimentary sequence and cored $108.7 \mathrm{~m}$ into an underlying volcanic sequence that represents acoustic basement at this site. However, a stuck bottom-hole assembly (BHA) was left in Hole 794C when Leg 127 scientists departed this site. This event ultimately resulted in Leg 128 scientists drilling two, rather than one, hole during their re-occupation of Site 794, which presented an unexpected opportunity to drill deeper into the volcanic basement sequence initially penetrated during Leg 127. In effect, this turn of events resulted in an unanticipated drilling bonus and led to a fourth major objective for Leg 128, which we would take full advantage of-that is, extended coring and sampling of the enigmatic acoustic basement rocks beneath the Yamato $\mathrm{Ba}$ sin.

All available geophysical data indicate that the Yamato Basin is underlain by anomalously thickened oceanic-type crust (Katao, 1988), with the depth to the crust/mantle boundary averaging $16 \mathrm{~km}$ (Fig. 6). Ludwig et al. (1975), Kobayashi (1985), and Tamaki (1988) all suggested that this unusual thickness, and most specifically the $3.5-\mathrm{km} / \mathrm{s}$ layer, probably is attributable to the presence of volcaniclastic deposits and

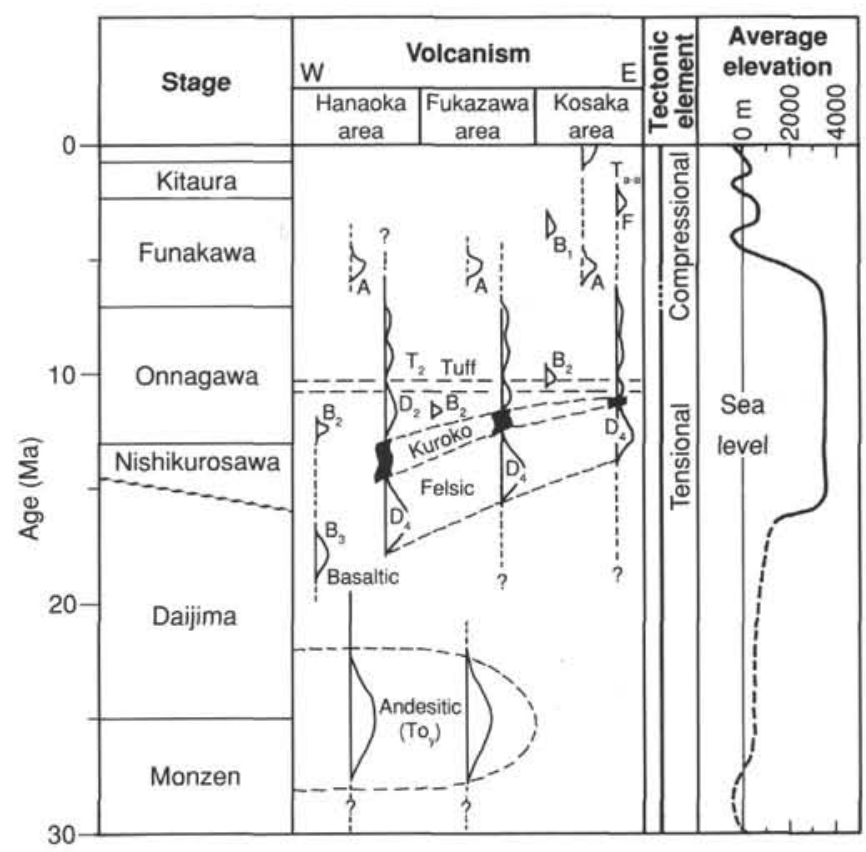

Figure 22. Summary of igneous, tectonic, and structural history and ages of Miocene volcanogenic sulfide mineralization in the Hokuroko mining district of northern Honshu, Japan. Symbols are as follows: A $=$ andesite, $\mathrm{B}=$ basalt, $\mathrm{D}=$ dacite, $\mathrm{F}=$ felsic igneous rock, and $\mathrm{T}=$ tuff. Stage names are equivalent to formation names applied in the Oga Peninsula coastal section located west of the Hokuroko district (Fig. 13). See Figures 2 and 21 for locations. Figure from Tanimura et al. (1983).

interbedded flow rocks correlative with the lower Miocene "Green Tuff' formations widely exposed on Honshu and recognized in dredge samples from the Yamato Basin area. These speculations are also supported by the fact that the dominant radiometric ages of volcanic rocks dredged from the Yamato Rise and the western slope of Honshu range from 22 to $24 \mathrm{Ma}$ (Kaneoka and Yuasa, 1988; Tamaki, 1988).

The volcanic rocks encountered below acoustic basement at Site 794 during Leg 127 drilling were interpreted as a series of lower Miocene(?) dolerite sills with minor interbedded tuff based upon shipboard analysis by our Leg 127 colleagues (Tamaki, Pisciotto, Allan, et al., in press). With this information in hand, we planned to wash/jet down through the sedimentary section at Site 794 and to begin coring the basement volcanic rocks at a depth overlapping the lowest dolerite unit cored in Holes 794B and 794C by Leg 127 scientists. Our goal was simple: to core as deeply into the volcanic sequence beneath Site 794 as possible in the time available prior to the pre-scheduled arrival of the two support vessels, which would dictate the start of planned geophysical experiments at this site.

\section{Microbiology}

Although bacteria are recognized as playing an important role in the diagenesis of marine sediments, their distribution and activities much below the sediment/water interface have yet to be fully established. It is known that bacterial activity is highest in surface sediments and declines with increasing depth. Limited sampling to date has shown that living bacteria are present to depths of at least $80 \mathrm{mbsf}$, based upon observations in ODP cores from the Peru margin (Craig et al., in press).

We recognized that the organic-rich pelagic sediments likely to be encountered during drilling at Site 798 on the Oki 


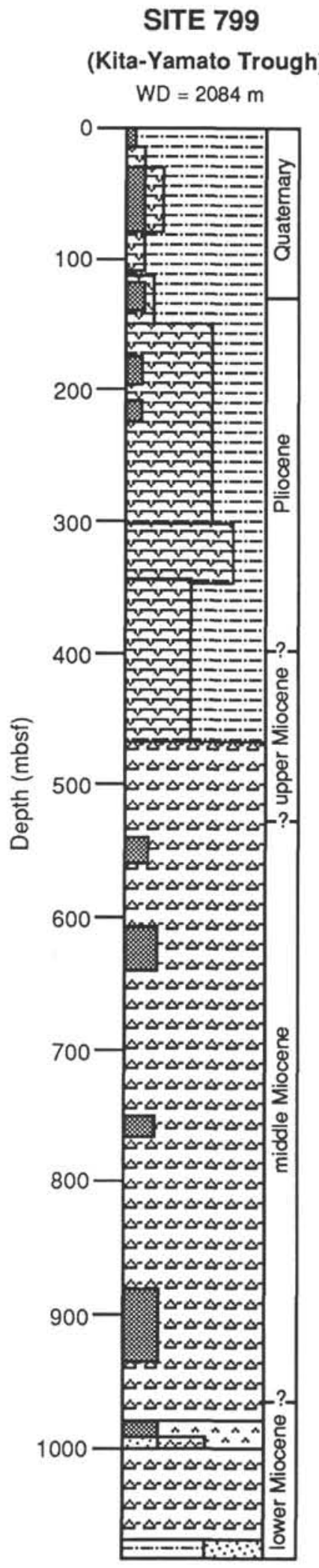

$\mathrm{TD}=1084 \mathrm{~m}$
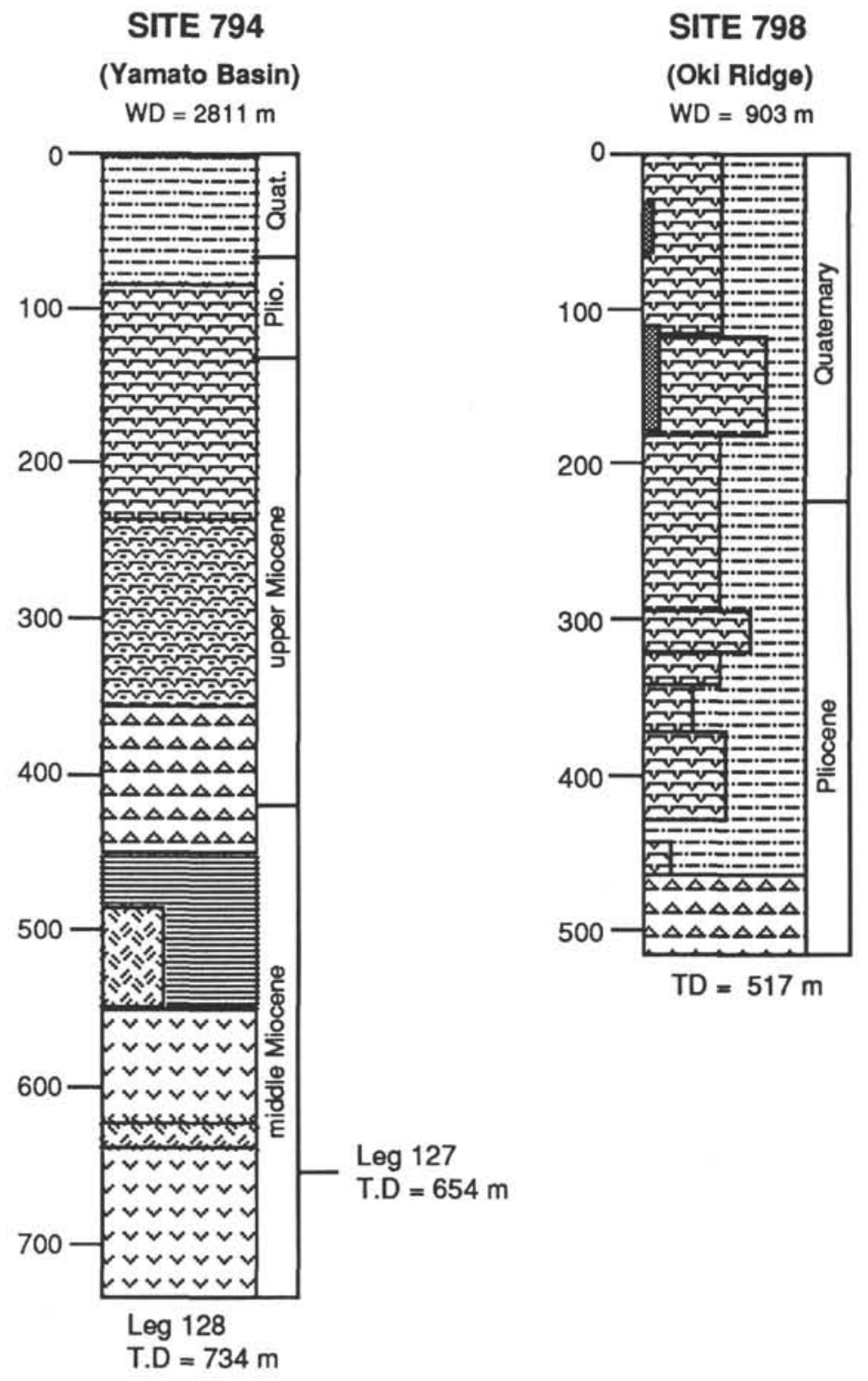

SITE 798

(OkI Ridge)

Leg 127$$
\text { m }
$$

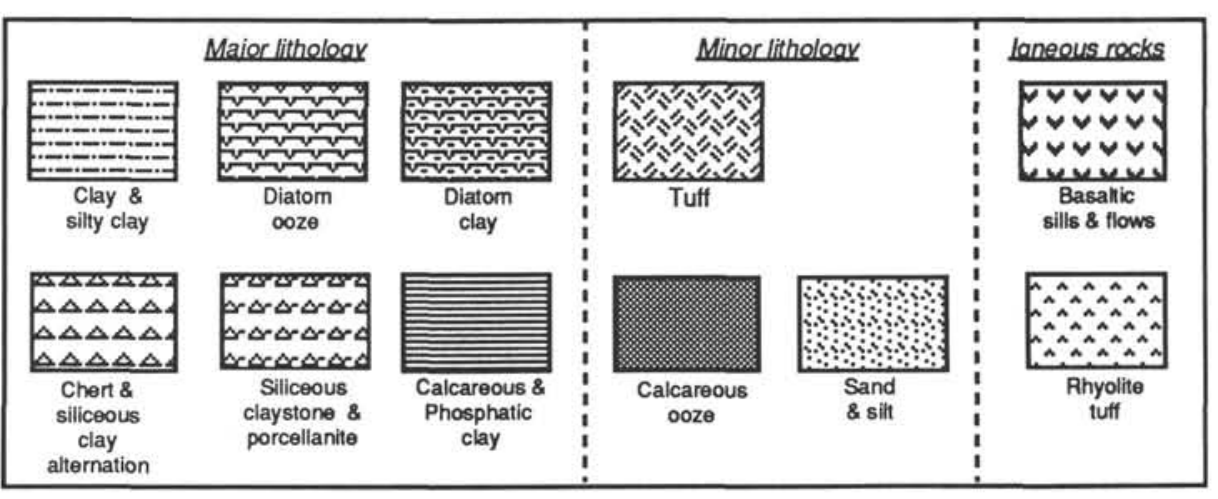

Figure 23. Summary stratigraphic columns and lithofacies for Leg 128 Sites 794 (northern Yamato Basin), 798 (Oki Ridge), and 799 (Kita-Yamato Trough), Japan Sea. Ages presented on these columns are based exclusively on shipboard analyses and subject to revision. Note that drilling during Leg 128 cored only the lowermost part of the column at Site 794, with the larger portion cored during Leg 127 (Fig. 4). See Figure 2 for locations. 


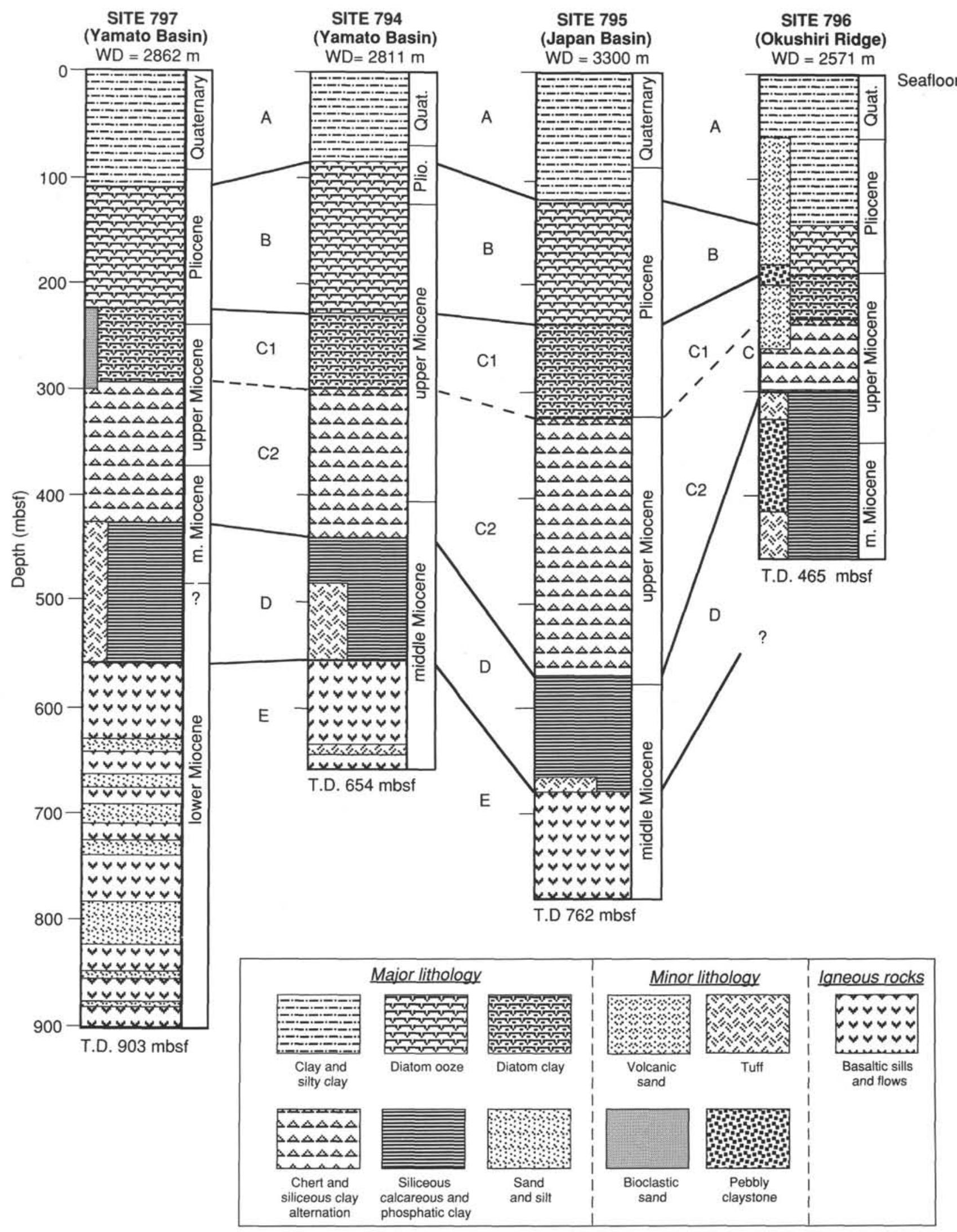

Figure 24. Summary stratigraphic columns and lithofacies for Leg 127 Sites 794 (northern Yamato Basin), 795 (Okishiri Ridge), 796 (northern Japan Basin), and 797 (southern Yamato Basin), Japan Sea, as presented by Tamaki, Pisciotto, Allan, et al. (in press). See Figure 2 for locations. 
Ridge in the Japan Sea would present an especially useful context in which to conduct detailed quantitative studies of bacteria at depth. A proposal outlining a sterile sampling technique to be applied to large whole-round samples to be taken at this site was put forward and ultimately accepted.

The primary objective of bacterial sampling and analysis at Site 798 was to quantify the role of bacteria in diagenesis by measuring their activity and biomass distribution within deep sediment layers using specially designed sterile sampling apparatus. Special arrangements were made to offload the bacterial samples 3 days after their collection so that they could be promptly transmitted by air to an onshore microbiological laboratory for analysis, which would include bacterial counts as well as analysis of bacterial composition and activity (sulfate reduction, etc.) and associated interstitial water.

\section{PRINCIPAL SHIPBOARD RESULTS}

We drilled three sites in the Japan Sea (Fig. 2 and Table 1) and essentially achieved all of our major drilling objectives, including recovery of a paleoceanographic reference section on Oki Ridge (Site 798) and a detailed depositional record of the Kita-Yamato failed-rift environment (Site 799). Despite stormy seas and a difficult transit schedule, we also accomplished all of our planned geophysical objectives at Site 794 in the northern Yamato Basin, including deployment of a borehole seismometer, initiation of long-term, ocean-based seismic observations, and large-scale measurements of the electrical resistivity of the crust beneath the Japan Sea. Due to a revised schedule we were also able to extend coring in the volcanic basement sequence initially sampled at Site 794 during Leg 127. Finally, we also completed our pioneering sterile sampling of bacteria at significant depths below the seafloor at Site 798. Summary stratigraphic columns for all three Leg 128 sites (Sites 794, 798, and 799) are presented in Figure 23. For comparison and correlation, we also include stratigraphic columns for the four Leg 127 sites (Sites 794, 795, 796, and 797), as presented by Tamaki, Pisciotto, Allan, et al. (in press; Fig. 24). As noted earlier, Site 794 was occupied during both Legs 127 and 128 and thus appears in both Figures 23 and 24, with Leg 128 drilling at this site delineated in Figure 23.

We were prevented from reaching our targeted sub-bottom depths at both Sites 798 and 799 because of shows of gas/ hydrocarbons; nevertheless, we were able to penetrate each of these sites to near-target depths and hence to obtain the stratigraphic data we sought. The major revision of our schedule mandated by events at Site 794 resulted in repeated transits between Sites 794 and 799. However, these circumstances ultimately worked in our favor and permitted us to drill an unscheduled hole at Site 794 and to extend coring successfully into the volcanic basement sequence beneath this site, which is of critical importance to our understanding of the early history of the Yamato Basin.

Both the bacterial sampling and geophysical experiments conducted during Leg 128 will require extensive onshore processing and analysis before results can be presented. Indeed, in the case of the long-term seismic observations using the borehole seismometer emplaced at Site 794 , the ocean-floor recording device must be retrieved before data can be processed. Hence, the results from these two programs are not included in this volume, although descriptions of shipboard procedures and observations are included in the appropriate site chapters. The results of onshore analysis stemming from both our geophysical experiments and our bacterial studies will be included in the Scientific Results volume of Leg 128.
The following sections provide brief summaries and overviews of our shipboard observations and analyses at all three Leg 128 sites and are presented in terms of the subdisciplines routinely reported within individual site chapters. Although these summary statements are written with specialists in mind, they also offer synopses of interest to the general reader.

\section{Lithostratigraphy}

The sedimentary sequences recovered at Sites 798 and 799 during Leg 128 consist predominantly of biosiliceous and diagenetically altered siliceous sediments, with siliciclastic and calcareous sediments showing only episodic dominance (Fig. 23). At Site 798 on Oki Ridge, $518 \mathrm{~m}$ of largely pelagic and hemipelagic sediments were cored and range from late early Pliocene to Holocene in age (Fig. 23). Site 799 in the Kita-Yamato Trough yielded $1084 \mathrm{~m}$ of sediment that ranged in age from early(?) Miocene to Holocene. The younger sedimentary units or lithofacies recognized in these sections are similar to correlative unit boundaries. Upper through lower Miocene lithofacies were cored only at Site 799. Hence, a generalized description of Leg 128 lithostratigraphy is given next in terms of the five basic lithofacies or stratigraphic units encountered sequentially downhole in both of these sequences (Fig. 23).

Unit $\mathrm{I}$ is characterized by a variegated suite of diatomaceous ooze, diatomaceous clay, clay, and silty clay, with nannofossil- and foraminifer-rich horizons forming minor lithologies. This unit reaches a thickness of $220 \mathrm{~m}$ at Site 799 and encompasses only Quaternary age ( $0-1.88 \mathrm{Ma})$ sediments, whereas the unit is $170 \mathrm{~m}$ thick at Site 797 and includes upper Pliocene (2.4 Ma) to Holocene sediments (Fig. 23). Most notably, Unit I at Site 798 includes remarkably developed rhythms of dark-colored laminated intervals, interbedded with light-colored massive and bioturbated intervals. The upper portion of Unit I is enriched in siliciclastic material, including turbidite units, compared with the older lithologies of this unit. Beds rich in calcareous debris are most common in the middle part of Unit I (Site 798: 40-140 mbsf; Site 799: 40-110 mbsf). Sedimentary structures are pronounced and important in Unit I sediments at Site 799, where a number of beds exhibit soft-sediment deformation along with evidence of debris flows. Bioturbation is common in Unit I at Site 798 and clearly expressed as burrows penetrating the interval interface of light/dark rhythms. Alternatively, at Site 799, bioturbation is virtually absent in the upper $117 \mathrm{~m}$ and below this level only indicated by a mottled sediment fabric. Discrete vitric ash beds are common in Unit I at both Sites 798 and 799. Unit I is correlative with Lithofacies A of Tamaki, Pisciotto, Allan, et al. (in press), as shown in Figure 24.

Unit II is marked by common biosiliceous oozes, clays, and mixed sediments, which are intercalated with diagenetic carbonates at Site 799, whereas this unit is barren of carbonate at Site 798. Unit II includes $235 \mathrm{~m}$ of sediments at Site 798 that range from latest to late Pliocene in age. At Site 799, Unit II is $287 \mathrm{~m}$ thick and was deposited during late Miocene through late Pliocene time. Unit III is correlative with Lithofacies B of the Leg 127 stratigraphic scheme presented by Tamaki, Pisciotto, Allan, et al. (in press).

Unit III consists of siliceous claystones and porcellanites, which are predominantly laminated in the upper $149 \mathrm{~m}$ and burrowed throughout the remainder of the unit. Unit III sediments reach a thickness of $343 \mathrm{~m}$ at Site 799 and range from middle to late Miocene in age. Only $63 \mathrm{~m}$ of Unit III were penetrated at Site 798 , and this yielded a late to late early Pliocene age; drilling at this site terminated in this unit (Fig. 23). Importantly, the boundary between Unit II and Unit III is 
defined by the transformation of opal-A to opal-CT and a corresponding increase in mean wet-bulk density, and by the irregular presence of dark/light sequences. At Site 799, the transformation of opal-CT into authigenic quartz was detected at approximately $585 \mathrm{~m}$. Authigenic carbonates, such as siderite and dolomite, are common in Unit III and appear as well-developed beds of more than $50 \mathrm{~cm}$ thick and most commonly as thin laminae, lenses, and concretions. In rare cases, nannofossils and foraminifers are recognized as the precursors of these authigenic sediments. Volcanic ashes are rare in Unit III, as opposed to their common occurrence in Unit I. Normal faults and accompanying networks of water escape structures are especially abundant in the middle portion of this unit at between 580 and 700 mbsf in Hole 799B. Unit III is approximately correlative with Lithofacies C of Tamaki, Pisciotto, Allan, et al. (in press; Fig. 24).

Unit IV is distinguished by the presence of finely laminated to thinly bedded siliceous claystones and porcellanites, which are intimately interlaminated with carbonate-rich laminae, lenses, and nodules. This unit is $220 \mathrm{~m}$ thick at Site 799 and ranges from early to middle Miocene in age (Fig. 23). Thin turbidites also mark Unit IV and consist of silt- to fine sand-sized siliciclasts and glauconite. Unit IV includes a prominent altered tuff breccia and rhyolite tuff more than $20 \mathrm{~m}$ thick near the base of this unit at Site 799 (981.3-1002.5 mbsf). This unit is of special interest for correlating the Site 799 sequence with the stratigraphy and acidic volcanism associated with the Kuroko sulfide deposits on Honshu (Figs. 21 and 22). Unit IV is approximately correlative with Lithofacies D of the Leg 127 lithostratigraphic scheme (Tamaki, Pisciotto, Allan, et al., in press; Fig. 24).

Unit $\mathrm{V}$ is characterized by the presence of coarse-grained siliciclastic sand beds, including individual beds up to $5 \mathrm{~m}$ thick and a noticeable decrease in authigenic carbonate compared to superjacent units. A total of $64 \mathrm{~m}$ of these distinctive sediments was cored at the base of the Site 799 sequence, when drilling halted in this unit at 1084 mbsf (Fig. 23). The sands in Unit V are immature and comprise mostly angular to subrounded quartz grains, as well as grains of feldspar, glauconite, biotite, pyrite, unidentified mafic minerals, and rock fragments. These sands are interbedded with siliceous claystones and claystones that contain benthic foraminifers with deep-water (bathyal) affinities. The presence of allochthonous shallow-water benthic foraminifers, wood fragments, and plant debris, as well as the presence of a sharp base, normal grading, interval lamination, and cross-laminated sequences, indicate deposition by turbidity flows, probably derived from nearby areas of shallow water. Unit V has been tentatively correlated with Lithofacies E of Tamaki, Pisciotto, Allan, et al. (in press), as cored at Site 797 in the southern Yamato Basin east of Site 799 (Fig. 2).

\section{Biostratigraphy}

Patterns of preservation, abundance, and distribution of microfossils in sediments recovered from Sites 798 and 799 in the Japan Sea largely reflect the geochemical character of the various benthic environments at the time of deposition (e.g., anoxic vs. oxic water, presence of shallow CCD, etc.) and the post-depositional diagenetic processes that have altered or removed biosiliceous and biocalcareous components in these sediments, including the production of opal-CT and dolomite. Calcareous microfossils and nannofossils commonly exhibit pronounced dissolution below the Pliocene/Pleistocene boundary, whereas siliceous microfossils are most seriously affected in the lower Pliocene and Miocene portions of the sediment column below the opal-A/opal-CT diagenetic transition. These general conditions were also found at Leg 127 sites in the Yamato and Japan basins (Tamaki, Pisciotto, Allan, et al., in press).

Compounding problems of microfossil preservation, the relatively high latitude of the Japan Sea, together with its incipient to complete isolation from the open Pacific Ocean, have dictated that low-diversity, cool-water benthic and planktonic microfaunas have been the rule in the sea for significant periods of Neogene time. Thus, routine application of low-latitude open-ocean biozonations is difficult and has forced scientists to erect provincial zonations and datum levels (e.g., Saito, 1963; Ling, 1975; Tsuchi, 1981). Alternatively, some groups (such as diatoms and silicoflagellates) have been successfully correlated with well-constrained oceanic zonations and offer relatively high-resolution control in those sediments in which they occur (e.g., Burckle and Opdyke, 1977; Koizumi, 1978, 1983, 1985; Kobayashi, 1988).

Siliceous microfossils, and most specifically diatoms, provided our primary and most confident means of biostratigraphic control and correlation at Sites 798 and 799, with radiolarians and silicoflagellates also offering useful datum levels (Fig. 25). However, the preservation and abundance of diatoms reduce drastically as the opal-A/opal-CT diagenetic transition is approached. Hence, the continuous and most confident application of diatom zones and datum levels was restricted to Quaternary through upper Miocene sediments (Fig. 25). For example, at Site 799, diatoms occur in good abundance and preservation to about $160 \mathrm{mbsf}$, where evidence of dissolution becomes apparent. Severity of dissolution below this latter depth is reflected by the removal of delicate forms, leaving residual floras that have been artificially enriched in Coscinodiscus marginatus, a robust form of little biostratigraphic value. Although diatoms occur sporadically below the opal-A/opal-CT boundary, those that remain are usually poorly preserved.

In spite of these diagenetic difficulties, biostratigraphically important forms, including Annellus cf. A. californicus and Thallassiosira tappanae were recognized in samples from below the opal-A/opal-Ct boundary at Site 799; these provide a middle to early Miocene age for otherwise undated sediments (Fig. 23).

Similarly, radiolarians also occur below the opal-A/opalCT boundary at Site 799 and commonly exhibit greater resistance to dissolution than diatoms (Fig. 25). In addition, exceptional states of preservation are present in isolated horizons, as exemplified by a recrystallized middle Miocene radiolarian assemblage representative of the Cyrtecapsella tertrapea Zone found at Site 799.

In short, severe dissolution of siliceous microfossils at levels below the opal-A/opal-CT boundary in both Sites 798 and 799 precluded their routine application in lower Pliocene sediments at Site 798 and in pre-upper Miocene sediments at Site 799 , although scattered occurrences of biostratigraphically important taxa do provide broad age assignments in older sediments. Above the opal-A/opal-CT boundary, diatoms, radiolarians, and silicoflagellates provide excellent biostratigraphic control in Japan Sea sediments (Fig. 25), although the use of Pacific Neogene zones is difficult because of the provincial aspects of some Japan Sea assemblages (Ling, 1975). Silicoflagellates were particularly useful in some horizons when used in conjunction with a local zonation erected during DSDP Leg 31 drilling in the Japan Sea (Ling, 1975).

Calcareous plankton, including both planktonic foraminifers and calcareous nannofossils, have also been severely dissolved or diagenetically destroyed at levels coincident with and below the formation of dolomite. Calcareous nannofossils range from rare to abundant in Quaternary sediments at both Sites 798 and 799, but generally exhibit effects of etching and 


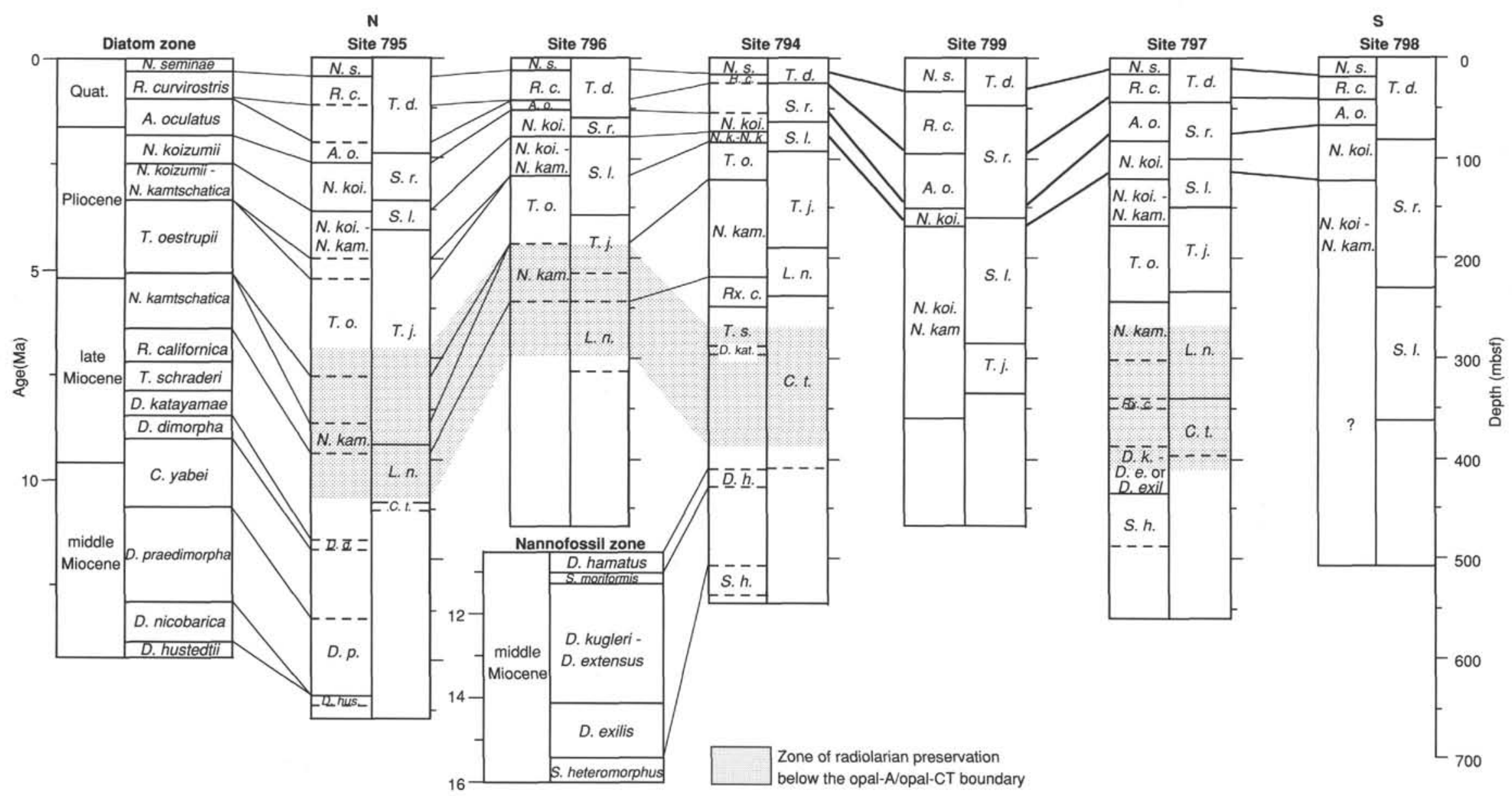

Figure 25. Biostratigraphic correlations of Legs 127 and 128 sites in the Japan Sea, based on diatoms, radiolarians, and calcareous nannofossils. Figure compiled from Legs 127 and 128 data by J. Alexandrovich and L. Burckle. 
dissolution, probably reflecting episodic dissolution events that are associated with the unusually shallow CCD in the Japan Sea. Calcareous nannofossils provide useful datums in Pliocene and Quaternary sediments where they are well preserved. As with siliceous microfossils, exceptions occur and identifiable and biostratigraphically useful taxa were encountered in sediments below zones of carbonate diagenesis.

Planktonic foraminifers were also affected by dissolution and carbonate diagenesis and exhibit patterns of preservation similar to calcareous nannofossils. Abundant and well-preserved assemblages occur in Pliocene through Quaternary sediments; these are typically dominated by subarctic to temperate species, reflecting generally cool surface temperatures in the sea during this time. Preliminary analysis of coiling ratios in Neogloboquadrina pachyderma within Pliocene-Pleistocene sediments indicates that this species was particularly sensitive to the frequent and extreme changes in surface circulation and temperature experienced by the Japan Sea as a result of eustatic and tectonic control of the shallow sills controlling exit and entrance of water to the sea.

Both planktonic microfossils and benthic foraminifers provide a wealth of paleoenvironmental and paleoceanographic information at both Sites 798 and 799 . Although the calcareous benthic foraminiferal record also reflects carbonate diagenesis, rapid burial in turbidites and replaced faunas, together with well-preserved faunas, allowed us to estimate paleobathymetry and the water mass character throughout the columns at both Sites 798 and 799. In addition, poorly preserved benthic foraminifers of deep-water affinity were found in the thin sediment horizon within the volcanic basement sequence at Site 794, suggesting extrusion of associated units on a deep basin floor. Shallow-water benthic taxa found in Kita-Yamato Trough sediments provide evidence of displacement of sands from nearby littoral and neritic environments.

Preliminary analysis of planktonic foraminifers, diatoms, and radiolarians at Site 799 indicates that the Japan Sea was warm and had open circulation with the adjacent Pacific Ocean during middle Miocene time, probably reflecting the dominance of water from the Kuroshio Current. Both siliceous and calcareous groups indicate that surface temperatures cooled in later Miocene time and were subarctic in portions of the Pliocene most of Pleistocene time. Oyashio water probably dominated these cooler intervals, along with restrictions imposed by eustatic and tectonic control of the gateways to the sea. These latter effects are most pronounced in the Quaternary light/dark cyclic sediments present at Site 798. Diatoms and planktonic foraminifers are much more abundant in the dark laminated layers of these cycles, reflecting enhanced preservation during these intervals. Quantitative faunal analysis of these sediments should yield a truly high-resolution record of the unusual paleoceanographic history of the sea during this period.

\section{Paleomagnetism}

Leg 128 scientists drilled seven holes at Sites 794, 798, and 799. Paleomagnetic studies were performed for cores from Holes 794D, 798A, 798B, 798C, 799A, and 799B. The main purpose of shipboard paleomagnetic analysis of sediment cores is to obtain a sequence of polarity transitions for use in determining the age of sediments. Toward this purpose, the primary components of remanence were isolated using the alternating field (AF) demagnetization technique. Because of the low intensity of the sediment cores, remanences were measured exclusively using a $2 G$ Enterprise cryogenic magnetometer.
Remanences measured in APC cores from Holes 798A, 798B, and 798C are well behaved, and the primary component was obtained at a demagnetization level of $10 \mathrm{Mt}$. Three APC cores provided consistent identifications of polarity transitions. The Brunhes/Matuyama boundary was observed at about 80 mbsf at Site 798 , while the Jaramillo normal event was observed between 90 and 100 mbsf. These boundaries in turn indicate a sedimentation rate of about $120 \mathrm{~m} / \mathrm{m}$.y.

At the termination of APC coring, Hole 798B was deepened down to $520 \mathrm{mbsf}$ by XCB coring. The remanence of the $\mathrm{XCB}$ cores was measured by taking discrete cube samples from each section of the cores. The Olduvai event was located between 190 and $210 \mathrm{mbsf}$, and the Matuyama-Gauss transition was located at 300 mbsf. The bottom part of Hole 798B continues to display normal polarity, suggesting an age within the Gauss normal polarity period. The bottom of Hole 798B ( $520 \mathrm{mbsf}$ ) corresponds to an age of about $3.5 \mathrm{Ma}$ by extrapolation. The average rate of sedimentation for the entire section in Hole 798B is about $125 \mathrm{~m} / \mathrm{m}$.y., although the bottom part seems to represent a slightly higher rate.

The upper $170 \mathrm{~m}$ of Hole 799A was cored using the APC. The split archive halves of these cores were measured using a cryogenic magnetometer. Although primary remanence is partly disturbed by slump structures in Cores $128-799 \mathrm{~A}-7 \mathrm{H}$ and $128-799 \mathrm{~A}-8 \mathrm{H}$, the Brunhes/Matuyama boundary was clearly located at $90 \mathrm{mbsf}$. This suggests a high rate of sediment accumulation in the upper part of Hole 799A (about $130 \mathrm{~m} / \mathrm{m} . \mathrm{y}$.). However, below this boundary, the sedimentation rate becomes very low, with the Matuyama/Gauss transition located at a depth of 155 mbsf.

Below Core 128-799A-20H, drilling was continued using XCB coring to a depth of 465 mbsf. Remanence directions in these cores are dispersive, and the identification of polarity boundaries is somewhat ambiguous. Although the Gauss/ Gilbert boundary was firmly located at $215 \mathrm{mbsf}$, remanences below this depth exhibit scattered results. Reversed polarity samples are dominant in the section between 215 and 390 mbsf. The section between 390 and 430 mbsf is normally magnetized, whereas the bottom portion of this sequence exhibits reversed magnetization (430-465 mbsf). Although some of the normal events within the Gilbert chron are missing, we conclude that the normal section between 390 and 430 mbsf corresponds to normal Chron 5, and the bottom reversed sediments correspond to Chron 6 . Adopting these boundaries and extrapolating sediment accumulation curves indicate that the basal sediments of Hole 799A were deposited during the middle part of the late Miocene (ca. $7 \mathrm{Ma}$ ). The overall sedimentation rate for the Hole $799 \mathrm{~A}$ sequence is about $65 \mathrm{~m} / \mathrm{m} . \mathrm{y}$.

Hole 799B was drilled using RCB coring, starting at a depth of 450 mbsf to its base at 1084 mbsf. Because of the low intensity of the magnetization in the cores recovered from Hole 799B, sensitivity of discrete sample measurements using the shipboard magnetometers was not sufficient. Hence, whole-core measurements on archive halves of the RCB cores were performed with the cryogenic magnetometer. Although reversed polarity was scattered in several parts of Hole 799B over an interval of several tens of centimeters, most cores were normally magnetized. We conclude that the remanence is not primary and has been affected by an overprint or re-magnetization of the Holocene normal field. Closed investigations of the remanence properties of these samples indicate that the sparsely magnetized portions of this interval have a relatively higher intensity than the normally magnetized parts. This suggests that the reversely magnetized section may possess a primary component of this remanence not obscured by this secondary component. However, because the high- 
intensity portions of the sequence are rare, we could not determine a sequence of polarity changes from shipboard observations. More detailed shore-based paleomagnetic analyses will be required to determine the polarity sequence in cores from Hole 799B.

Paleomagnetic studies were also conducted on the igneous rocks cored at Site 794. The remanence of these rocks was measured using a Minispin spinner magnetometer and the demagnetization performed using a Schonstedt AC demagnetizer. These volcanic basement rocks have a high intensity of magnetization, and the presence of remanence properties indicates they are suitable for a paleomagnetic study. The primary component of the magnetization was easily isolated. Significantly, stable inclinations of six out of the seven lithologic units analyzed exhibit reversed polarity, although direct evidence of the age of these basement rocks cannot be obtained from shipboard paleomagnetic studies.

\section{Sediment Accumulation Rates}

Estimated rates of sediment accumulation at Sites 798 and 799 are based primarily on diatom datum levels and paleomagnetic reversal stratigraphy in upper Miocene through Quaternary sediments (Fig. 26). The absence of well-preserved microfaunas and a stable paleomagnetic signature in older horizons precludes confident estimates of accumulation for these sediments. We have also included the accumulation rate curve for Site 794, as analyzed by Tamaki, Pisciotto, Allan, et al. (in press) during Leg 127 (Fig. 26).

Rates of sediment accumulation at Site 798 are constrained by six magnetic reversals, three diatom datum levels, one calcareous nannofossil datum, and three silicoflagellate datum levels (Fig. 26). Sedimentation rates at this site range from less than $45 \mathrm{~m} / \mathrm{m}$.y. to more than $261 \mathrm{~m} / \mathrm{m}$.y., with an average rate of $121 \mathrm{~m} / \mathrm{m} . . \mathrm{y}$. The sedimentation rate for the upper Quaternary portion of the Site 798 sequence, which includes the most prominent light/dark depositional cycles, is about $120 \mathrm{~m} / \mathrm{m}$.y., a rate that includes deposition of the common volcanic ashes in this sequence.

Estimated rates of sediment accumulation at Site 799 in the Kita-Yamato Trough are based on nine magnetic reversals and three diatom datum levels, all restricted to the late Miocene through Holocene portion of this sequence (Fig. 26). Calculated rates vary from $1 \mathrm{~m} / \mathrm{m}$.y. to more than $175 \mathrm{~m} / \mathrm{m}$.y., with an average rate of about $70 \mathrm{~m} / \mathrm{m}$.y. Accumulation rates in the late Quaternary are in excess of $100 \mathrm{~m} / \mathrm{m}$.y., similar to those estimated for the same interval at Site 798 (Fig. 26). The Quaternary-Pliocene sedimentation rates at both Sites 798 and 799 are more than twice as high as the average rates estimated for this period at Leg 127 basinal sites, as exemplified by the curve for Site 794 (Fig. 26). The high rates at Sites 798 and 799 probably reflect their location within narrow basins having steep slopes that has encouraged downslope transport of both fine and coarse debris.

A speculative extrapolation of the Site 799 sedimentation curve is presented in Figure 26. This is based on the occurrence of a poorly preserved calcareous nannofossil flora in the lower part of this sequence, which can be interpreted as representative of a broad late early to early middle Miocene age (Fig. 26), in turn pointing to an early Miocene age for the base of the Site 799 sequence.

\section{Inorganic Geochemistry}

Interstitial waters were extracted from sediments at both Site 798 on Oki Ridge and Site 799 in the Kita-Yamato Trough during Leg 128. A total of 38 interstitial water samples were collected at Site 798, with high-density sampling in the upper 100 mbsf. A total of 49 interstitial water samples from 31 cores

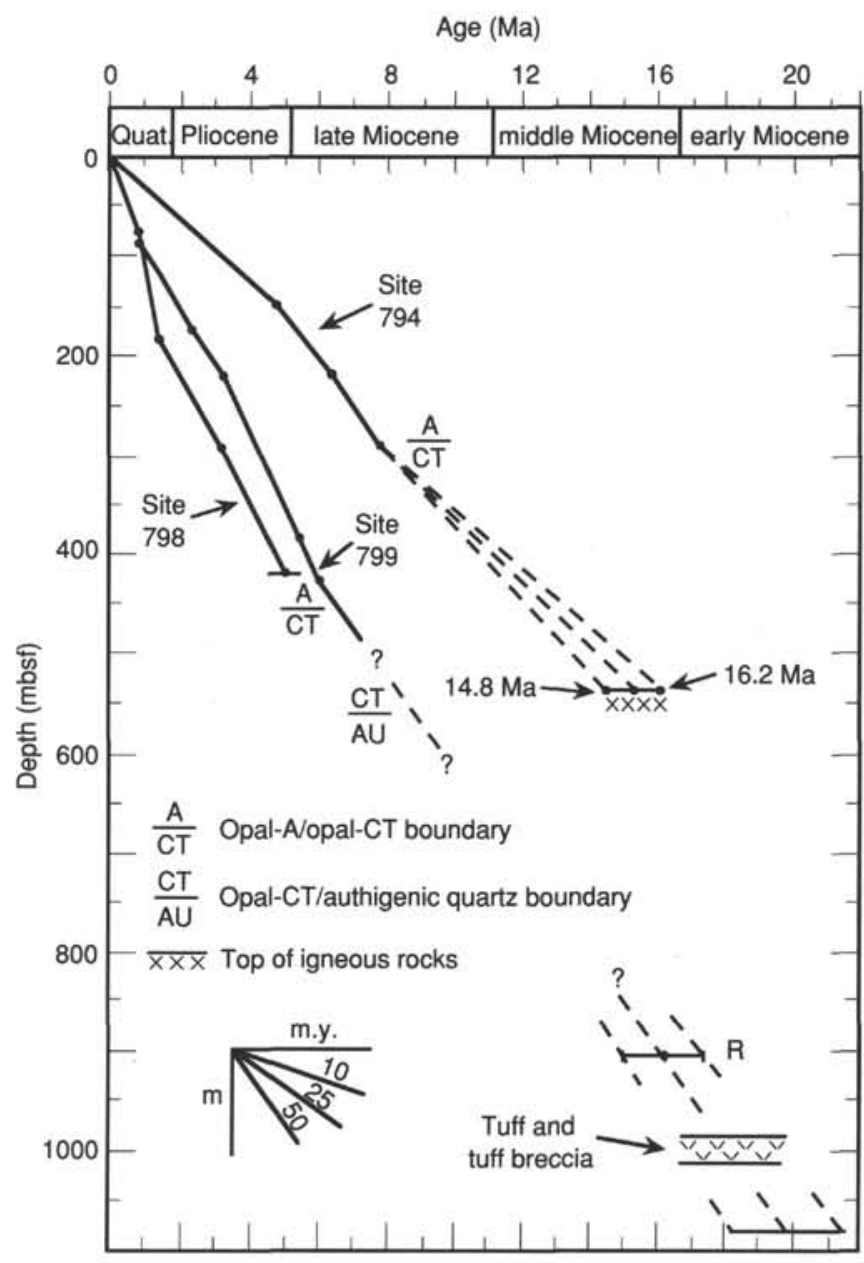

Figure 26. Summary of sedimentation rates (age vs. depth) at Leg 128 Sites 798 (Oki Ridge) and 799 (Kita-Yamato Trough), and Site 794 (northern Yamato Basin) shared with Leg 127. Curve for Site 794 from Tamaki, Pisciotto, Allan, et al. (in press). Extrapolation of the Site 799 curve to basement is speculative because of limited biostratigraphic control.

were collected from Site 799 . Of the 31 cores sampled at Site 799,16 were sampled at adjacent intervals in Hole 799A. Shipboard chemical analyses of dissolved constituents in the interstitial waters of Leg 128 sediments include $\mathrm{pH}$, alkalinity, salinity, chlorinity, phosphate, ammonia, silica, magnesium, calcium, potassium, sulfate, lithium, and manganese. Results of geochemical analyses of the interstitial waters from both sites suggest that fluid/solid exchange reactions associated with sulfate reduction, organic matter degradation, dolomitization, opal-A/opal-CT transformation, and clay mineral crystallization influence the chemical composition of the interstitial waters.

Dissolved sulfate is depleted in interstitial waters at a depth of only 12 mbsf at Site 798 and at 28 mbsf at Site 799. Mobilization of manganese occurs at both sites within the zone of intense sulfate reduction. Evidence for the degradation of organic matter can be seen in the phosphate and ammonia profiles. Dissolved phosphate profiles exhibit a pronounced maximum at 37 mbsf in interstitial waters of Site 798 and at 28 mbsf at Site 799. Dissolved ammonia increases steadily downhole to about 250 mbsf at Site 798 and about 436 
mbsf at Site 799 , then concentrations decrease with depth to the bottom of the hole at both sites. Total alkalinity concentrations increase in pore waters, recorded at both sites and resulting from organic matter decomposition in near-surface sediment, are accompanied by decreases in dissolved calcium, indicating inorganic calcite precipitation. Dolomitization by replacement of magnesium for calcium in previously formed inorganic calcite at both sites is indicated by a change from negative slope to positive slope in the magnesium/calcium molar ratios with depth. The dissolved magnesium/calcium molar ratio in interstitial waters from Site 798 exhibits a sharp turnaround at $70 \mathrm{mbsf}$. The turnaround in magnesium/calcium molar ratio at Site 799 can be seen at 220 mbsf, which suggests that dolomitization is occurring earlier in sediments at $\mathrm{Oki}$ Ridge than in the Kita-Yamato Trough.

The transition from opal-A (biogenic silica) to opal-CT is recorded in the profile of dissolved silica in interstitial water by a clear gradient change as dissolved silica is incorporated into opal-CT phases. Such a turnaround in concentration of dissolved silica occurs at 370 mbsf at Site 798 and at 408 mbsf at Site 799. Opal-A/opal-CT transformation is occurring later than dolomitization in sediments at both Sites 798 and 799 . Clay mineral crystallization is suggested by decreasing concentrations of dissolved potassium in the lower interstitialwater sampling intervals at both sites, which might result from the removal of potassium from the clay-mineral solids.

Interstitial waters associated with sediments from below 430 mbsf at Site 799 exhibit concentration profiles for $\mathrm{pH}$, chlorinity, salinity, magnesium, potassium, calcium, strontium, and lithium that cannot be explained by normal burial diagenetic reactions. This change in interstitial geochemical character coincides with stratigraphic units of low porosity and high bulk density composed of dolomite and opal-CT. The low-porosity, high-bulk-density units act as a lithologic barrier across which interstitial water chemical exchange is not occurring or is occurring at a very slow rate. The interstitial water mass isolated below this lithologic barrier has geochemical characteristics that suggest at least two fluid sources. One source of dissolved chemical constituents may be the dissolved products of basement alteration reactions diffusing or advecting into overlying sediment interstitial waters. Evidence for hydrothermal influence is seen in increased concentrations of dissolved calcium and in decreased concentrations of magnesium, chlorinity, and total salinity. A second source for dissolved constituents in these interstitial waters below the lithologic barrier may be advection of near-normal seawater along high-permeability sand units, such as those found at the base of Hole 799B. Evidence for horizontal advection of interstitial water includes four intervals that exhibit concentrations of chlorinity, salinity, $\mathrm{pH}$, potassium, calcium, and strontium that are closer to the chemical composition of normal seawater than the diagenetically altered interstitial waters immediately above this lithologic barrier. Coarse sands present in the Kita-Yamato Trough sequence may be suitable conduits for importing fluids by horizontal advection.

\section{Organic Geochemistry}

Three important characteristics of the Miocene to Holocene sediments penetrated during Leg 128 drilling were documented using shipboard organic geochemical measurements. These are summarized in the following paragraphs.

Significant concentrations of calcium carbonate are restricted to the upper portion of the sediment columns cored at both Sites 798 and 799. Calcium carbonate contents at Site 798 range from $1 \%$ to $35 \%$ in the interval from 0 to $215 \mathrm{mbsf}$. Below this depth, carbonate contents are less than $5 \% \mathrm{CaCO}_{3}$ equivalent, and the carbonate mineralogy is dominated by dolomite. While $\mathrm{CaCO}_{3}$ contents are lower at Site 799 than at Site 798 , once again the rocks having the highest contents of $\mathrm{CaCO}_{3}$ occur in the upper $125 \mathrm{~m}$ of the hole. Below $125 \mathrm{mbsf}$, calcium carbonate is abundant only locally, occurring as concretions and carbonate phases of importance in this interval.

The sediments at both Sites 798 and 799 are enriched in organic carbon relative to typical open-marine sediments, with an average total organic carbon (TOC) value at Site 798 of $1.8 \%$ and with the average value at Site 799 greater than $1.25 \%$. This enrichment reflects high surface productivity and enhanced preservation of organic matter in suboxic bottom waters by rapid burial by turbidites. Carbon/nitrogen ratios are low at both sites, indicating that organic matter is dominated by material derived from marine sources. However, organic matter from terrestrial sources is an important component of many of the intervals richest in organic carbon. Carbon/sulfur ratios are displaced slightly above those considered typical of "normal marine" settings, consistent with the presence of poorly oxygenated bottom waters.

Light hydrocarbons are abundant in sediments at both Sites 798 and 799. Methane is abundant in all cores from depths below $1 \mathrm{mbsf}$, and numerous gas voids developed in cores taken from unconsolidated sediments. Methane was the most abundant of the hydrocarbon gases encountered, but significant amounts of ethane, propane, iso-butane, $n$-butane, and higher hydrocarbons were observed as well. At Site 798, sharp decreases in the $C_{1} / C_{2}$ ratio to values of 36 forced us to halt drilling at $517.9 \mathrm{mbsf}$. At Site $799, \mathrm{C}_{1} / \mathrm{C}_{2}$ ratios were as low as 57 . Because these hydrocarbon ratios were decreasing smoothly with increasing depth, we continued to drill to 1068.1 mbsf, where a yellow-white cut fluorescence was observed. Samples taken from the next core also produced a yellow-white cut fluorescence, which forced us to halt drilling in Hole $799 \mathrm{~B}$ at 1084 mbsf.

\section{Igneous Rocks and Tephra}

\section{Igneous Rocks}

Site 794 was drilled during both Leg 127 and Leg 128. The primary drilling objectives were rocks that represented acoustic basement below the northern Yamato Basin. Initially, Leg 127 scientists were successful in this endeavor, and they recovered a full sedimentary sequence and then penetrated an underlying sequence of volcanic rocks and minor sediment representing the acoustic basement target. Because of special circumstances, Leg 128 scientists were able to drill and core deeper into this volcanic sequence, aiding our collective attempt to characterize igneous basement beneath this backarc basin.

A total of $34.9 \mathrm{~m}$ of core was retrieved from Hole 794D between 573.0 and 733.5 mbsf. Eight igneous units and one interbedded sedimentary unit were encountered, with the entire sequence ultimately assigned to two successive volcanic complexes. From top to bottom, the upper of these two complexes includes four units, emplaced into marine sediments. The four units include a thick, plagioclase-phyric, dolerite laccolith, a dolerite basalt sheet flow, and two aphyric dolerite sills. The volcanic formations are more or less contemporaneous with sedimentation. The deepest recovered sedimentary unit is a clayey silt having a basalt hydroclastic layer at its base; this thin unit contains poorly preserved benthic foraminifers, indicating its marine origin. The lower volcanic complex consists of four units; from the top to bottom these units include an olivine-basalt flow, two doleritic basalt flows or very shallow-depth sills, and one olivinedolerite sill. This second complex has been widely penetrated 
by hydrothermal veins of talc, chlorite, quartz, calcite, and pyrite, and has been interpreted as representing igneous basement below the Yamato Basin.

All of the petrographic and petrochemical indicators obtained on board the JOIDES Resolution during Leg 128 indicate that these rocks belong to tholeiitic magmas. Textural and structural features are consistent with fissure eruptions of two successive volcanic pulses in the same tectonic setting. The geochemical trace-element data clearly indicate that the two complexes represent two distinct magmatic series. The older and lower complex is an ocean floor basalt of back-arc theoliitic composition (niobium-depleted and large-ion, lithophile-element-enriched). The younger and upper complex is an island arc theoliite (moderate to highly lithophile-elementenriched). Calc-alkaline affinity increases with time in these rocks. The dolerite laccolith, the last magmatic supply, is a plagioclase-cumulate andesitic basalt.

Structural analysis of the fractures and veins in these rocks indicates an early phase of compression in the basement (e.g., the lower volcanic complex).

\section{Summary of Volcanic Ash Record}

Exceptional records of explosive volcanic activity in the central and eastern Japan Sea were collected at both Sites 798 and 799 during Leg 128. By combining data from these two sites, an almost complete record representing early Pliocene through Quaternary events was acquired because of the continuous sedimentation at these sites, the excellent preservation of the ashes, and the reasonably good recovery of sediments in these sequences. Ashes not recovered in Pliocene strata were recognized clearly and enumerated by means of the formation microscanner (FMS) logging tool. Miocene sediments were retrieved only in Hole 799B. Here, the ashes are highly altered but still recognizable; however, the record is incomplete.

At Site 798 on Oki Ridge, ash deposition consists of 0.1 - to 15 -cm-thick, homogeneous-to-graded, air-fall pyroclastic layers of acidic-to-intermediate magmatic composition. A total of 113 discrete ash layers were recovered that correspond to 113 successive volcanic events dating from late early Pliocene to Holocene. They originated mainly from ultraplinian to subplinian eruptions of Japan arc volcanoes. In the Kita-Yamato Trough, drilling at Site 799 recorded 223 air-fall pyroclastic layers, 0.1 to $20 \mathrm{~cm}$ thick and mostly of acidic composition, that range in age from early Miocene to Holocene. In addition, portions of a $24-\mathrm{m}$-thick rhyolite tuff of probable submarine origin were recovered near the bottom of Hole 799B. The Pliocene-Quaternary ashes at Site 799 , all of ultraplinian to plinian type, may have originated either from the Japan Arc, the Korea Plateau, and/or the volcanoes of northeastern China. The Miocene tephra layers at Site 799 (as well as the thick rhyolite tuff) indicate the proximity of a distinctive volcanic chain.

The number and thickness of ash layers were plotted as a function of time to estimate the chronologic evolution of nearby explosive volcanic activity. Ten pulses of volcanism in three main stages were detected in this manner. Three pulses in the Miocene correspond to the thick rhyolite tuff and to a strong and then moderate basic-to-intermediate proximal activity. The rhyolite eruption may be correlative with the acidic volcanism associated with the Kuroko massive sulfide ores in northern Japan.

After a short gap in tephra deposition during the late Miocene, three volcanic pulses are registered from the late Miocene to late Pliocene. Two partial gaps in tephra deposition, between 4.2 and $3.4 \mathrm{Ma}$ at Site 799 and between 3.5 and
2.4 Ma at Site 798, indicate that the two sites did not receive exactly the same volcanic supply over this time span.

Four pulses of explosive volcanism are distinguished in Quaternary time, with a strong increase in the early Pleistocene and paroxysmal activity between 1 and $0.3 \mathrm{Ma}$. Following a weak decrease in activity, Holocene activity is estimated as moderate to high intensity.

\section{Physical Properties}

The objectives of the physical properties program during Leg 128 were to characterize the physical properties of Japan Sea sediments and rocks and to provide an important link between geophysical data and the geological realities of the materials that constitute the sedimentary section described by the shipboard sedimentologists and stratigraphers.

This physical properties program consisted of obtaining the following measurements: (1) index properties, including gravimetric determinations of bulk density, porosity, water content, and grain density; (2) vane shear strength, a relative measure of the resistance of sediments to loads and a measure of its cohesiveness; (3) compressional-wave velocity or the speed of sound in sediments; and (4) thermal conductivity, representing a measure of the ability of a sediment to transport heat.

The sedimentary record of Site 798 can be divided into three major lithologic units. The upper $20 \mathrm{~m}$ of the sedimentary column shows a greater influence of terrigenous material. A second major boundary is located at a depth of $220 \mathrm{mbsf}$, where carbonate content decreases abruptly. The third boundary is located at a sub-bottom depth of about $460 \mathrm{mbsf}$ and is marked by the transition of opal-A to opal-CT. The upper 20 $\mathrm{m}$ of this section is characterized by a generally low wet-bulk density, whereas high values for water content and porosity were recorded in the same interval. The decrease of carbonate content at a sub-bottom depth of $220 \mathrm{~m}$ has no dramatic influence on physical properties, whereas the boundary between opal-A and opal-CT is marked by high wet-bulk density values, the maximum value for thermal conductivity, and a low water content and porosity.

The upper $170 \mathrm{~m}$ of the sedimentary column at Site 799 is characterized by terrigenous material, turbidites, and debris flow deposits. The depth range from 170 to $420 \mathrm{mbsf}$ is marked by a high abundance of siliceous material. The depth interval below about 420 mbsf exhibits the transition of opal-A to opal-CT. The upper $120 \mathrm{mbsf}$ is characterized by generally higher wet-bulk and grain densities, whereas lower values for water content and porosity were determined. This silica-rich depth interval exhibits generally lower values for wet-bulk and grain densities, whereas higher porosities and water content values were determined. The boundary between opal-A and opal-CT is marked by high wet-bulk density and generally lower values of water content and porosity.

\section{Downhole Measurements}

A complete suite of four combination logging runs was obtained from 70 to 518 mbsf in Hole 798B. The most significant result of the downhole measurements program at Hole 798B was the detection of climate cycles in the logs. The Oki Ridge is a strategically positioned location for paleoclimatic studies, and its high sediment accumulation rate make it an ideal site to test the sensitivity of downhole logs as a paleoclimatic tool. Extracting paleoclimatic information from downhole logs has been problematic in the past because sedimentation rates are generally too low for the logs to resolve adequately sedimentary climate cycles. Hole 798B logging data are recorded at $15-\mathrm{cm}$ intervals, which is equivalent to a high temporal sampling resolution ( $\sim 1$ k.y.). Be- 
cause of the environmental setting and the excellent quality of data, Hole 798B logging results present the best opportunity in the history of ODP logging to recover detailed paleoclimatic information from downhole logs.

The geochemical and physical property logs exhibit remarkable cyclicity to a depth of $\sim 300$ mbsf, which encompasses late Pliocene through Quaternary time. Most of the variance in the logs can be explained in terms of variations in terrigenous sediment and biogenic opal content, which recur at a $\sim 41-k$.y. periodicity. This periodicity is the same as the period of Earth's orbital tilt variations. Moreover, previous late Neogene paleoclimate studies have shown that many elements of climate (e.g., glacial volume, continental aridity, temperature of sea's surface) also vary predominantly at this periodicity. The Hole 798B log cycles are similar in character to the late Neogene record of loess deposition in central China; thus, these logging data may reflect periodic variations in the supply of eolian dust from Asian sources.

A complete suite of four combination logging runs also was completed in Hole 799A (to $469 \mathrm{mbsf}$ ) and in Hole 799B (to $1064 \mathrm{mbsf}$ ) in the Kita-Yamato Trough. In addition, an experiment in vertical seismic profiling was conducted at Hole 799B. The most important logging results at Site 799 included caliper data from the FMS, which indicated that the borehole in Hole 799A was elliptical and that its orientation is consistent with the regional paleostress field of the Kita-Yamato Trough. Further, the logging data below $\sim 400$ mbsf from Holes 799A and 799B show marked increases in sediment rigidity and bulk density, consistent with the increase in diagenetic opal-CT at this depth. The logs show a further shift to increased sediment rigidity at $\sim 600 \mathrm{mbsf}$, which mineralogical analyses indicate is the depth of authigenic quartz formation. The logs also are useful for identifying the numerous dolomite layers present at Site 799 below $\sim 400$ mbsf, which are poorly represented in core material and adversely affected core recovery. Another logging highlight involved the use of FMS images from Hole 799B to identify westwarddipping $\left(\sim 20^{\circ}\right)$ sediment layers between 970 and 980 mbsf. Ash layers can be identified at Site 799 as defined by their thorium and uranium geochemistry from the natural gammaray spectroscopy tool, adding further detail to analysis of logs from Site 799. Finally, data from the vertical seismic profiling experiment at Site 799 will be used to define the vertical seismic character of this sequence and the character of deep structure below the hole.

Logging in the igneous sequence cored at Site 794 during Leg 128 was limited to one and one-half runs because of the poor hole conditions. Only the seismic stratigraphic combination and a partial FMS run were completed. Principal logging results at Site 794 included use of gamma-ray and resistivity and velocity data from our first run to delineate individual igneous and sedimentary/altered ash layers. The lowermost part of Hole 794D is characterized by log responses of high porosity, high gamma-ray values, and low sonic velocity, which suggests that sediments, not igneous rocks, were the final materials drilled in Hole 794D. The FMS images returned from this hole can be used to define the orientation and scale of fault and fracture structures in the uppermost part of the hole.

\section{Seismic Stratigraphy}

The seismic stratigraphy at Leg 128 drilling sites added further information about the seismic nature of sediments and basement in the Japan Sea to that described at Leg 127 sites by Tamaki, Pisciotto, Allan, et al. (in press). Whereas Leg 127 sites were mainly located in the Japan and Yamato basins, Leg 128 targeted bathymetric highs, including the Oki Ridge and the Yamato Rise, where depressions in acoustic basement are commonly bounded by normal faults that form grabens, as described by Tamaki (1988).

Important reflection data that complement existing seismic profiles were obtained at both Site 798 (Oki Ridge) and Site 799 (Kita-Yamato Trough) by scientists on board the JOIDES Resolution. Fewer seismic data were available at these two sites relative to the density of seismic profiles available at other ODP sites in the Japan Sea.

Seismic intervals were correlated with lithologic units at both Sites 798 and 799 using constraints from sonic-velocity $\log$ data and physical-property velocity measurements. Drilling was terminated before reaching acoustic basement at both of these sites because of shows of gas and hydrocarbons. However, correlations of seismic data with sequences drilled clearly show that we penetrated the lowermost sedimentary layers above acoustic basement at both Sites 798 and 799. At Site 799, vertical seismic profiling (VSP) was performed so that depths could be directly correlated to traveltimes.

Site 798 on Oki Ridge is located in a small basement depression where sediment is about $0.8 \mathrm{~s}$ thick (two-way traveltime). We identified five seismic intervals in this section that could be recognized elsewhere in this ridge-top basin and adjacent areas. The upper sediments in this sequence are reflective, display four seismic intervals, and correlate with sediments dominated by clay and diatom ooze. Lower seismic Interval 5 represents a siliceous claystone, is more transparent, and displays changes in thickness. The most prominent reflectors in the profiles from Site 798 seem to correlate with dolomitic layers, as inferred from logging data. The opal-A/opal-CT boundary may be located at about 450 mbsf within Interval 5 , but it does not form a distinctive reflector.

Five seismic intervals were also recognized from Site 799 profiles, where the total sediment column is represented by a 1.3-s interval above acoustic basement. Interval 2 at Site 799, composed mainly of diatomaceous ooze, is transparent and bottoms at the opal-A/opal-CT boundary. Again, the most prominent reflectors appear to correlate with dolomitic horizons, especially within Interval 4, which is characterized by many strong reflectors. Evidence of sedimentary deformation is apparent below Interval 2.

Thus, the strongest reflectors observed at both Sites 798 and 799 are probably the result of dolomitic horizons. Significantly, the presence of these discrete horizons within sequences of predominantly diatomaceous sediment provides a reflective appearance to otherwise seismically transparent units. In addition, strong reflectors were found to be associated with units that displayed greater deformation at depth in both of these sites.

\section{CONCLUSIONS}

ODP Leg 128 set sail from Pusan, Korea, on 26 August 1989. The shipboard scientific party spent the following 52 days successfully drilling three sites in the eastern and central Japan Sea (Fig. 2; Table 1), with the primary goals of (1) recovering a paleoceanographic reference section at Site 798 on Oki Ridge, (2) detailing the depositional history of a failed-rift thought to represent a potential setting for back-arc metallogeny at Site 799 in the Kita-Yamato Trough, and (3) conducting two large-scale geophysical experiments at Site 794 in the northern Yamato Basin with the objective of clarifying the deep structure beneath the Japan Sea and adjacent arc-trench subduction zone. We successfully accomplished all of these objectives and, in addition, extended coring into the volcanic sequence underlying the northern Yamato Basin at Site 794. 
Leg 128 was the second of two consecutive ODP legs aimed at deciphering the tectonic and oceanographic history of the Japan Sea as a major example of a back-arc basin formed in a continental-arc setting. Despite gas shows, typhoons, and stuck tools, both Legs 127 and 128 completed their complementary missions, and the Japan Sea now stands as one of the best-documented back-arc basins in the world ocean and of special significance to our understanding of the orogenic cycle common to convergent margins of all ages.

Here, we highlight our principal conclusions at each of the Leg 128 sites, with the chapters that follow providing the details of our observations and shipboard analyses, along with expanded statements regarding our results and conclusions.

\section{Site 798 (Oki Ridge)}

Our major objective at Site 798 was to recover a Miocene to Holocene paleoceanographic reference section in pelagic sediments that had been deposited in an isolated ridge-top basin above the shallow CCD depth of the Japan Sea. We also planned to conduct a unique program of sterile microbiological sampling at this site to quantify the distribution and role of bacteria in the diagenesis of organic-rich, deep-marine sediments.

From drilling at Site 798, we recovered an outstanding late early Pliocene through Holocene pelagic-hemipelagic sequence (Fig. 23) that is rich in siliceous and calcareous plankton and exhibits remarkable light/dark depositional cycles clearly representing major oscillations in the oceanographic behavior of the Japan Sea. In addition, this sequence contains a detailed record of explosive volcanism in the adjacent Japan Arc in the form of well-reserved vitric ashes. Although drilling was halted before we reached our target bottom depth because of a show of gas, it is evident that this sequence encompasses a high-resolution record of PliocenePleistocene paleoclimatic and paleoceanographic events in the eastern Japan Sea in a location directly under the present track of the Tsushima Current.

The $518 \mathrm{~m}$ of lower Pliocene through Holocene sediments cored at Site 798 exhibit three different lithofacies, including an uppermost Pliocene to Holocene unit composed of clays, diatomaceous sediments, and ashes. This latter unit displays a visually striking sequence of high-frequency laminated/ bioturbated cycles. Older Pliocene to upper lower Pliocene sediments include diatomaceous clays that are underlain by carbonate-poor claystone containing ash and glauconitic and quartz sandstones. The coarse sands of the basal unit stand in contrast to the increasingly pelagic character of younger sediments in this sequence, suggesting that Oki Ridge became increasingly isolated during Quaternary time, perhaps as a result of tectonic uplift similar to events expressed along the adjacent margin of Honshu and the Oki Islands to the south.

The remarkable late Pliocene through Pleistocene depositional cycles present within the Site 798 sequence represent one of the drilling highlights of Leg 128. These cyclic sediments exhibit a constant depositional couplet consisting of a basal dark laminated diatomaceous unit rich in organic matter and an overlying light-colored homogeneous to bioturbated unit with abundant terrigenous material and relatively low organic matter. The cycles are best developed in the upper Quaternary sediments and clearly reflect high-frequency variations in the oceanographic state or mode of the Japan Sea that involve extremes of surface-water productivity, dissolved oxygen content of bottom water, and the flux of fine-grained terrigenous material to the sea. The dark, laminated, organicrich intervals indicate near-anoxic bottom water, with associated abundant diatoms, calling for high productivity in the overlying surface water. Alternatively, the light-colored, bioturbated, terrigenous layers may represent a fully oxic mode in the evolution of bottom water. Further, the natural gammaray $\log$ patterns recorded through these sediments exhibit a periodicity of about $40 \mathrm{k} . \mathrm{y}$., which is very near the 41-k.y. periodicity of Earth's orbital tilt, thought to be a major factor in controlling Quaternary climate.

The extremely shallow sills that nearly isolate the modern Japan Sea from the Pacific Ocean may have been periodically severed by eustatic lowstands of sea level in the Quaternary, in turn inducing bottom-water anoxia, with highstands of sea level associated with the hyperventilated and fully oxic mode of circulation exhibited by the modern Japan Sea (Fig. 17). However, similar but less well-developed cyclic deposits are present in Pliocene sediments. Hence, other scenarios for the formation of the cycles are open to confirmation by research, making these unusual sediments a high priority for post-cruise study.

Another major attribute of the Site 798 sequence is the unusually detailed record of Pliocene-Pleistocene explosive volcanism, represented by 113 discrete ash layers present in these sediments. Excellent paleomagnetic and biostratigraphic age control in this sequence should allow for quantitative assessment of explosive activity in the nearby Japan Arc, with a major pulse occurring between 4.0 and $3.5 \mathrm{Ma}$. Activity again increased between 2.5 and $1.3 \mathrm{Ma}$. The frequency of ashes that increased rapidly in lower Pleistocene sediments provides evidence of maximum explosive activity between 0.7 and $0.55 \mathrm{Ma}$.

\section{Site 799 (Kita-Yamato Trough)}

Our major objective at Site 799 was to detail the depositional history of the Kita-Yamato Trough, a sediment-filled graben within the larger Yamato Rise thought to represent a failed-rift environment ideal for the occurrence of volcanogenic massive sulfide deposits of the Kuroko or shale-hosted variety. The thick Neogene column within the trough was also expected to yield an expanded paleoceanographic record for the central Japan Sea.

Drilling at Site 799 penetrated $1084 \mathrm{~m}$ of lower Miocene through Holocene sediments. Drilling was halted about $120 \mathrm{~m}$ short of acoustic basement because of a show of gas and a fluorescent cut. Five lithologic units were recognized in this sequence, and all five can be correlated with lithofacies encountered in Leg 127 drilling sites elsewhere in the sea, including Site 797 in the adjacent Yamato Basin (Figs. 23 and 24). The lithofacies encountered at Site 799 reflect paleoceanographic events in the evolution of the sea in terms of variations in the abundance of biosiliceous and biocalcareous material. Alternatively, the tectonic development of the Yamato Rise and the failed rift are expressed in terms of coarse terrigenous units and sedimentary structures occuring in lower Miocene and Pleistocene portions of the sequence. These basic patterns have been severely overprinted by diagenetic changes to these sediments, with the appearance of dolomites and the opal-A/opal-CT boundary coincident with major changes in the physical properties and geochemistry of the sediment column, including interstitial waters.

Basal lower Miocene sediments at Site 799 include coarse turbidite sands rich in plant debris and other evidence of rapid transport from nearby shallow-water and terrestrial environments during the early rifting phase of the rise. Benthic foraminifers in these sediments indicate that these sands were deposited at bathyal water depths. Consequently, substantial subsidence had occurred prior to the deposition of these units. A distinctive rhyolite tuff occurs near the lower/middle $\mathrm{Mi}$ ocene boundary in this sequence and appears to correlate with 
the pulse of acidic volcanism that is associated with deposition of the Miocene Kuroko sulfide deposits on Honshu.

The lower Miocene coarse deposits are overlain by middle Miocene hemipelagic diatomaceous and calcareous sediments and genetically related porcellanites. These rocks represent a facies seen throughout the Japan Sea and correlate in part with the Onnagawa Formation of the Oga Peninsula and related units that are exposed along the western coast of Honshu (Figs. 13 and 14). Laminated organic-rich units apparently mark suboxic phases in the history of bottom water resulting from expanded oxygen minima or the effects of basin silling.

Upper Miocene and lower Pliocene deposits include diatomaceous muds and claystones that require high productivity and little dilution from terrigenous material. These sediments also contain large amounts of organic matter. Faunas and floras associated with these deposits include cool-water biofacies.

The youngest deposits in the Kita-Yamato Trough sequence include diatomaceous oozes, which give way to more terrigenous deposits and volcanic ashes. Upper Quaternary deposits include major slump units. These seismic profiles suggest a causal relationship between slumping along the sides of the trough and explosive volcanic events marked by discrete ashes.

\section{Site 794 (Northern Yamato Basin)}

Our original objective at Site 794 was to conduct two large-scale geophysical experiments that involved two vessels to deploy a downhole seismometer, the initiation of long-term seismic observations using a borehole seismometer, and an oblique electrical resistivity experiment. Both of these experiments were aimed at gaining new insights into the deep structure beneath the Japan Sea, using ocean-based seismic and electrical measurements. As it turned out, a stuck BHA in Hole $794 \mathrm{C}$ and our pre-arranged meeting with two support ships for the geophysical experiments ultimately led to a revised schedule for Leg 128 and an unexpected opportunity to extend coring into the volcanic sequence that had first been penetrated at this site during Leg 127.

We successfully performed the two geophysical experiments originally scheduled for Site 794, as detailed in the Site 794 site chapter that follows. The results of our analyses of these data will be presented in the Scientific Results volume of Leg 128. Processing of data from the multiship experiment using the borehole seismometer and a seafloor OBS array should yield new data about local crustal structure. The program of long-term observations using the downhole seismometer will yield data that will be used to determine a three-dimensional view of the structure of the crust and mantle beneath the Japan Sea. Data from the oblique electrical resistivity experiment will provide a picture of the resistivity structure to a depth of $10 \mathrm{~km}$ below the Japan Sea.

The highest priority identified for ODP drilling in the Japan Sea was coring and dating of rocks that represent acoustic basement beneath the Japan and Yamato basins to obtain data critical for reconstructing the early history of the sea and for determining the age of rapid spreading thought to be responsible for the formation of these basins. Leg 128 drilling at Site 794 penetrated $190.5 \mathrm{~m}$ into the igneous complex that was first cored at this site during Leg 127. Our shipboard analysis of these rocks resulted in our recognizing nine predominantly igneous units; our analysis was substantially aided by the use of the FMS logging tool to recognize unit boundaries.

Shipboard petrologic and geochemical analyses of the volcanic sequence at Site 794 indicated that these rocks represent a series of stacked sills and flows, which in turn represent two magmatic complexes. The upper and younger sets of dolerites and flows are of probable island-arc tholeiite composition. A minor sedimentary unit within this complex contains deep-water benthic foraminifers.

The lower and older complex in this sequence includes sills and flows that comprise ocean-floor basalts composed of back-arc tholeiites. An olivine-pyroxene basaltic flow rock within this complex having a primitive composition is thought to represent igneous basement at this site.

\section{REFERENCES}

Abe, K., and Kanamori, H., 1970, Mantle structure beneath the Japan Sea as revealed by surface waves. Bull. Earthquake Res. Inst., Univ. Tokyo, 48:1011-1021.

Arai, F., Oba, T., Kitazato, H., Horibe, Y., and Machida, H., 1981. Late Quaternary tephrochronology and paleo-oceanography of the sediments of the Japan Sea. Quat. Res. (Tokyo), 20:209-230 (in Japanese with English abstract).

Asano, K., Takayanagi, Y., and Takayama, T., 1975. Late Neogene epic boundaries in Japan. In Saito, T., and Burkle, L. (Eds.), Late Neogene Epic Boundaries: New York (Micropaleo. Press), 115123.

Barash, M. S., 1986. The paleoceanographic conditions of the formation of the late Miocene phosphatic horizon of the North Yamato Rise (Sea of Japan). Oceanology, 26:721-724 (in Russian).

Becker, K., 1985. Large-scale electrical resistivity and bulk porosity of the oceanic crust, Hole 504B. In Anderson, R. H., Honnorez, J., et al., Init. Repts. DSDP, 70: Washington, (U.S. Govt. Printing Office), 419-427.

Beloussov, V. V., 1968. Some problems of development of the earth's crust and upper mantle of oceans. In Knopoff, L. (Ed.), The Crust and Upper Mantle of the Pacific Area: Washington, D.C. (Am. Geophys. Union), 449-459.

Bersenev, I. I., Lelikov, E. P., Bezverkhniy, V. L., Yashchenikova, N. G., Sledin, V. G., Terezov, E. P., and Choi, I. V., 1987. Geology of the Japan Sea: Vladivostok (Pacific Oceanological Inst.)(In Russian).

Boggs, S., Jr., 1984. Quaternary sedimentation in the Japan arc-trench system. Geol. Soc. Am. Bull., 95:669-685.

Bouma, A. H., 1975, Deep-sea fan deposits from the Toyama Trough, Sea of Japan. In, Karig, D. E., Ingle, J. C., Jr., et al., Init. Repts. DSDP, 31: Washington (U. S. Govt. Printing Office), 489-495.

Burckle, L., and Akiba, F., 1978. Implications of late Neogene freshwater sediment in the Sea of Japan. Geology, 6:123-127.

Burckle, L., and Opdyke, N., 1977. Late Neogene diatom correlations in the Circum-Pacific. In Saito, T., and Ujiie, H. (Eds.), Proc. First Int. Congress on Pacific Neogene Stratigraphy: Tokyo (Kaiyo Shuppan Publ. Co.), 255-284.

Celaya, M., and McCabe, R., 1987. Kinematic opening of the Sea of Japan and the bending of the Japanese islands. Geology, 15:53-57.

Chinzei, K., 1978. Neogene molluscan faunas in the Japanese Islands; an ecologic and zoogeographic synthesis. The Veliger, 21:155-170. 1986a. Opening of the Japan Sea and marine biogeography during the Miocene. J. Geomag. Geoelectr., 38:487-494.

$1986 \mathrm{~b}$. Faunal succession and geographic distribution of Neogene molluscan faunas in Japan. Palaeontol. Soc. Japan, 29:17-29.

Chough, S. K., 1984. Fine-grained turbidites and associated massflow deposits in the Ulleung (Tsushima) back-arc basin, East Sea (Sea of Japan). In Stow, D. A., and Piper, D.J.W. (Eds.), FineGrained Sediments: Deep-Water Processes and Facies: Oxford (Blackwell Publ. Co.), 185-196.

Craig, B. A., Parkes, R. J., Fry, J. C., Herbert, R. A., Wimpenny, J.W.T., and Getliff, J. W., in press. Bacterial biomass and activity profiles within deep sediment layers. In Suess, E., von Huene, R., et al., Proc. ODP, Sci. Results, 118: College Station, TX U.S.A. (Ocean Drilling Program).

Fujioka, K., 1986. Synthesis of Neogene explosive volcanism of the Tohoku arc, deduced from marine tephra drilled around the Japan Trench region, Deep Sea Drilling Project Legs 56, 57, and 87B. In Kagami, H., Karig, D. E., Colbourn, W. T., et al., Init. Repts. DSDP, 87: Washington, (U.S. Govt. Printing Office), 703-726. 
Fukao, Y., and Furumoto, M., 1975. Mechanism of large earthquakes along the eastern margin of the Japan Sea. Tectonophysics, 25:247-266.

Francheteau, J., Needham, H. O., Choukroune, P., Juteau, T., Sequiet, M., Ballard, R. D., Fox, P. J., Normark, W., Carranza, A., Cordoba, D., Guerro, J., Rangin, C., Bougault, H., Cambon, P., and Hekinian, R., 1979. Massive deep-sea sulfide ore deposits discovered on the East Pacific Rise. Nature, 277:523-528.

Francis, T.J.G., 1982. Large-scale resistivity experiment at DSDP Hole 459B. In Hussong, D. M., Uyeda, S., et al., Init. Repts. DSDP, 60: Washington (U.S. Govt. Printing Office), 841-856.

Gladenkov, Y. B., 1984. Neogene stratigraphy of Northeast Asia (Kamchatka, Sakhalin). In Ikebe, N., and Tsuchi, R. (Eds.), Pacific Neogene Datum Planes: Tokyo (Univ. Tokyo Press), 235-243.

Gnibidenko, H., 1979. The tectonics of the Japan Sea. Mar. Geol., 32:71-87.

Halbach, P., Nakamura, K., Wahsner, M., Lange, J., Sakai, H., Kaselitz, L., Hansen, R. D., Yamano, M., Post, J., Prause, B., Seifert, R., Michaelis, W., Teichmann, F., Kinoshita, M., Marten, A., Ishibashi, J., Czerwinski, S., and Blum, N., 1989. Probable modern analogue of Kuroko-type massive sulfide deposits in the Okinawa Trough back-arc basin. Nature, 338:496497.

Hayashida, A., 1986. Timing of rotational motion of southwest Japan inferred from paleomagnetism of the Setouchi Miocene series. $J$. Geomag. Geoelectr., 38:295-310.

Hibbard, J. P., and Karig, D. E., 1990. Alternative plate model for the early Miocene evolution of the southwest Japan margin. Geology, $18: 170-174$

Hidaka, K., 1966. Japan Sea. In Fairbridge, R. (Ed.), Encylopedia of Oceanography: New York (Reinhold Publ. Corp.), 417-424.

Hilde, T. W., and Wageman, J. M., 1973. Structure and origin of the Japan Sea. In Coleman, P. J. (Ed.), The Western Pacific: Island Arcs, Marginal Seas, Geochemistry: Nedsland (Univ. Western Australia), 415-434.

Hirata,, N. Kinoshita, H., Suyehiro, K., Suyemasu, M., Matsuda, N., Ouchi, T., Katao, H., Koresawa, S., and Nagumo, S., 1987. Report on DELP cruises in the Japan Sea. Part II: Seismic refraction experiment conducted in the Yamato Basin, southeast Japan Sea. Bull. Earthquake. Res. Inst., Univ. Tokyo, 62:347-365.

Hirata, N., Tokuyama, H., and Chung, T. W., in press. An anomalously thick layering of the crust of the Yamato Basin, southeastern Japan Sea: the final stage of back-arc spreading. Tectonophysics.

Hirooka, K., 1987. Opening of the Japan Sea and the Neogene tectonic event of the Japanese Islands inferred from paleomagnetism. In Tsuchi, R. (Ed.), Pacific Neogene Event Studies: Shizuoka (Shizuoka Univ.), 29-31.

Honza, E. (Ed.), 1978. Geological Investigations in the Northern Margin of the Okinawa Trough and the Western Margin of the Japan Sea, April-May 1977 (GH 77-2 Cruise). Geol. Surv. Japan, Cruise Rept., 10:1-79.

1979. Geological Investigation of the Japan Sea. Geol. Surv. Japan, Cruise Rept., 13:1-99.

Hoshi, K., 1988. Miocene Ocean Floor Metamorphism During BackArc Spreading in the Japan Sea: Stanford (Stanford Univ.), unpubl. M.S. thesis.

Ichikura, M., and Ujiie, H., 1976. Lithology and planktonic foraminifera of the Sea of Japan. Bull. Natl. Sci. Mus. (Tokyo), Ser. C (Geol.), 2:151-181.

Iijima, A., Tada, R., and Watanabe, Y., 1988. Developments of Neogene sedimentary basins in the northeastern Honshu arc with emphasis on Miocene siliceous deposits. J. Fac. Sci., Univ. Tokyo, 21:417-466.

Ikebe, Y., and Maiya, S., 1981. Akita and Niigata areas. In Tsuchi, R. (Ed.), Neogene of Japan-Its Biostratigraphy and Chronology: Shizuoka (Kurofune Printing Co.), 68-75.

Ingle, J. C., Jr., 1975a. Pleistocene and Pliocene planktonic foraminifera from the Sea of Japan, Leg 31, Deep Sea Drilling Project. In Karig, D. E., Ingle, J. C., Jr., et al., Init. Repts. DSDP, 31: Washington (U.S. Govt. Printing Office), 693-702.

1975b. Summary of late Paleogene-Neogene stratigraphy, paleobathymetry, and correlations, Philippine Sea and Sea of
Japan region. In Karig, D. E., Ingle, J. C., Jr., et al., Init. Repts. DSDP, 31: Washington (U.S. Govt. Printing Office), 837-855. 1981. Origin of Neogene diatomites around the North Pacific rim. In Garrison, R. E., Douglas, R., Pisciotto, K., Isaacs, C., and Ingle, J. C., Jr. (Eds.), The Monterey Formation and Related Siliceous Rocks of California: Los Angeles (Soc. Econ. Paleont. Mineral., Pacific Sec.), 159-179.

Iomoda, Y., and Fujimoto, H., 1982. Maps of gravity anomalies and bottom topography in the Western Pacific. Bull. Ocean Res. Inst., Univ. Tokyo, 14:1-158.

Ishiwada, Y., Honza, E., and Tamaki, K., 1984. Sedimentary basins of the Japan Sea. Proc. 27th Int. Geol. Congress, 23:43-65.

Jolivet, L., 1986. America-Eurasia plate boundary in eastern Asia and the opening of marginal basins. Earth Planet. Sci. Lett., 81:282288.

Jolivet, L., Huchon, P., and Rangin, C., 1989. Tectonic setting of western Pacific marginal basins. Tectonophysics, 160:23-47.

Kaneoka, I., 1986. Constraints on the time of the evolution of the Japan Sea based on radiometric dates. J. Geomag. Geoelectr., 38:475-485.

Kaneoka, I., and Yuasa, M., 1988. ${ }^{40} \mathrm{Ar} /{ }^{39} \mathrm{Ar}$ age studies of igneous rocks dredged from the central part of the Japan Sea during GH78-2 Cruise. Geochem. J. Japan, 22:195-204.

Karig, D. E., 1971. Origin and development of marginal basins in the western Pacific. J. Geophys. Res., 84:6796-6802.

Karig, D. E., Ingle, J. C., Jr., et al., 1975. Init. Repts. DSDP, 31: Washington (U.S. Govt. Printing Office).

Katao, H., 1988. Seismic structure and formation of the Yamato Basin. Bull. Earthquake. Res. Inst., Univ. Tokyo, 63:51-86.

Kawai, N., 1961. Deformation of Japanese Islands as inferred from rock magnetism. Geophys. J., 6:124-129.

Kim, B. K., 1977. On the Neogene deposits in southern Korea. In Saito, T., and Ujiie, H. (Eds.), Proc. First Int. Congress on Pacific Neogene Stratigraphy: Tokyo (Kaiyo Shuppan Co. Ltd.), 115118.

Kimura, G., and Tamaki, K., 1986. Collision, rotation, and back-arc spreading in the region of the Okhotsk and Japan Seas. Tectonics, 5:389-401.

Kobayashi, H., 1988. Neogene silicoflagellate biostratigraphy of the Japan Sea coastal region, with reference to DSDP Hole 438A. Tohoku Univ., Sci. Repts., 2nd Ser., 59:1-98.

Kobayashi, K., 1985. Sea of Japan and Okinawa Trough. In Nairn, A.E.M., Stehli, F. G., and Uyeda, S. (Eds.), The Ocean Basins and Margins. Vol. 7A. The Pacific Ocean: New York (Plenum Press), 419-457.

Koizumi, I., 1978. Neogene diatoms from the Sea of Japan. Mar. Geol., 26:231-248.

1983. Sedimentary environments of Neogene diatomaceous sediments, west coast of Japan. In Iijima, A., Hein, J., and Sevier, R. (Eds.), Siliceous Deposits in the Pacific Region: Amsterdam (Elsevier), 347-360.

1985. Diatom biochronology for the late Cenozoic Northwest Pacific. J. Geol. Soc. Japan, 91:195-211.

1988. Early Miocene Proto-Japan Sea. Paleontol. Soc. Korea, 4:6-20.

1989. Holocene pulses of diatom growths in the warm Tsushima Current in the Japan Sea. Diatom Res., 4:55-68.

Lallemand, S., and Jolivet, L., 1985. Japan Sea: a pull apart basin. Earth Planet. Sci. Lett, 76:375-389.

Lee, J.-S., and Pouclet, A., 1988. Le volcanisme néogene de Pohang (SE Corée), nouvelles constraintes géochronologiques pour l'ouverture de la Mer du Japon. C. R. Acad. Sci. Paris, Ser. II, 307:1405-1411.

Leg 127 Scientific Drilling Party, 1989. Exploring the Japan Sea. Geotimes, 34:19-21.

Ling, H. Y., 1975. Radiolaria: Leg 31 of the Deep Sea Drilling Project. In Karig, D. E.., Ingle, J. C., Jr., et al., Init. Repts. DSDP, 31: Washington, (U.S. Govt. Printing Office), 703-761.

Ludwig, W. J., Murauchi, S., and Houtz, R. E., 1975. Sediments and structure of the Japan Sea. Geol. Soc. Am. Bull., 86:651-664.

Masuzawa, J., and Akamatsu, H., 1962. Hydrographic observation during JEDS-4. Oceanographical Mag., 13:122-130.

Matoba, Y., 1984. Paleoenvironment of the Sea of Japan. Benthos '83: Pau (Elf Aquitaine), 409-414. 
Minster, J. B., and Jordan, T. H., 1978. Present-day plate motions. J. Geophys. Res., 83:5331-5354.

Miyake, Y., Sugimura, Y., and Matsumoto, E., 1968. Ionium-thorium chronology of Japan Sea cores. Rec. Oceanogr. Works Japan, 9:189-195.

Nakaseko, K., and Sugano, K., 1973. Neogene radiolaria zonation in Japan. Geol. Soc. Japan, Mem., 8:23.

Niino, H., Emery, K. O., and Kim, C. M., 1969. Organic carbon in sediments of the Japan Sea. J. Sediment. Petrol., 39:1390-1398.

Oba, T., 1983a. Oxygen isotope analysis. In Kobayashi, K. (Ed.), Preliminary Report of the Hakuho-maru Cruise KH 82-4: Tokyo (Ocean Res. Inst., Univ. Tokyo), 140-141.

1983b. Paleoenvironment of the Sea of Japan since the last glacial epoch. Gekkan Chikyu (The Earth Monthly), 5:38-46 (in Japanese).

Ohmoto, H., 1983. Geologic setting of the Kuroko deposits, Japan. In Ohmoto, H., and Skinner, B. (Eds.), The Kuroko and Related Volcanogenic Massive Sulfide Deposits. Econ. Geol. Monogr. 5: New Haven (Econ. Geol. Publ. Co.), 9-24.

Ohmoto, H., and Skinner, B. J. (Eds.), 1983. The Kuroko and related volcanogenic massive sulfide deposits. Econ. Geol. Monogr. 5: New Haven (The Econ. Geol. Publ. Co.), 1-604.

Ohowada, M., and Tanioka, K., 1972. Cruise report on the simultaneous observation of the Japan Sea in October 1969. Oceanographical Mag., 23:47-58.

Otofuji, Y., Hayashida, A., and Torii, M., 1985. When was the Japan Sea opened? Paleomagnetic evidence from southwest Japan. In Nasu, N. (Ed.), Formation of Active Ocean Margins: Tokyo (Terra Scientific Publ. Co.), 551-566.

Otofuji, Y., and Matsuda, T., 1983. Paleomagnetic evidence for clockwise rotation of southwest Japan. Earth Planet. Sci. Lett., 62:349-359.

1987. Amount of clockwise rotation of Southwest Japanfan shaped opening of the southwestern part of the Japan Sea. Earth Planet. Sci. Lett., 85:289-301.

Otofuji, Y., Matsuda, T., and Nohda, S., 1985. Paleomagnetic evidence for Miocene counter-clockwise rotation of Northeast Japan-rifting process of the Japan Arc. Earth Planet. Sci. Lett., 75:265-277.

Otsuki, K., 1989. Reconstruction of the Neogene tectonic stress field of NE Honshu arc from metalliferous veins. Mem. Geol. Soc. Japan, 32:281-304.

Saito, T., 1963. Miocene planktonic foraminifera from Honshu, Japan. Tohoku Univ., Sci. Repts., 2nd. Ser., 35:123-209.

Sato, T., Takayama, T., and Kudo, T., 1988. Calcareous microfossil biostratigraphy of the uppermost Cenozoic foramations distributed in the coast of the Japan Sea. Part 3: Akita area and Oga Peninsula. J. Japanese Assoc. Pet. Tech., 53:199-212.

Seno, T., and Maruyama, S., 1984. Paleogeographic reconstruction and origin of the Philippine Sea. Tectonophysics, 102:53-84.

Sugi, N., Chinzei, K., and Uyeda, S., 1983. Vertical crustal movements of north-east Japan since middle Miocene. In Hilde, T. W., and Uyeda, S. (Eds.), Geodynamics of the Western PacificIndonesian Region. Geodynamics Ser. 1: Washington (Am. Geophys. Union), 317-330.

Suzuki, U., 1979. Petroleum geology of the Sea of Japan, northern Honshu. Japanese Assoc. Pet. Tech., 44:291-307.

Taira, A., Tokuyama, H., and Soh, W., 1989. Accretion tectonics and the evolution of Japan. In Ben-Avraham, Z. (Ed.), The Evolution of the Pacific Ocean Margins: New York (Oxford Univ. Press), 100-123.

Takayama, T., 1977. On the geological age of the "Hojuji diatomaceous mudstone" Noto Peninsula, based on calcareous nannofossils. Annu. Sci. Kanazawa Univ., 14:71-79.

Takayasu, T., and Matoba, Y. (Eds.), 1976. Guidebook for Excursion 1. Oga Peninsula. First Int. Congress Pacific Neogene Stratigraphy: Shizuoka (Kurofune Print. Co. Ltd.).

Tamaki, K., 1986. Age estimation of the Japan Sea on the basis of stratigraphy, basement depth, and heat flow data. J. Geomag. Geoelectr., 38:427-446.

1988. Geological structure of the Sea of Japan and its tectonic implications. Bull. Geol. Surv. Japan, 39:269-365.

Tamaki, K., and Honza, E., 1985. Incipient subduction and obduction along the eastern margin of the Japan Sea. Tectonophysics, 119:381-406.
Tamaki, K., Honza, E., Yuasa, M., Nishimura, K., and Murikami, F., 1981. Geological map of the central Japan Sea. Geol. Surv. Japan, Mar. Geol. Map Series, 15.

Tamaki, K., Ingle, J. C., Jr., Pisciotto, K., Suyehiro, K., Allan, J. F., and von Breymann, M. T., 1989. Ocean Drilling Program Legs 127 and 128 Scientific Prospectus: College Station (Ocean Drilling Program).

Tamaki, K., and Kobayashi, K., 1988. Geomagnetic lineation in the Japan Sea. Mar. Sci. Monthly, 20:705-710 (in Japanese).

Tamaki, K., Pisciotto, K., Allan, J., et al., in press. Proc. ODP, Init. Repts, 127: College Station (Ocean Drilling Program).

Tanimura, S., Date, J., Takahashi, T., and Ohomoto, H., 1983. Stratigraphy and structure of the Hokuroku District. In Ohmoto, H., and Skinner, B. (Eds.), The Kuroko and Related Volcanogenic Massive Sulfide Deposits. Econ. Geol. Monogr. 5: New Haven (Econ. Geol. Publ. Co.), 24-38.

Tatsumi, Y., Otofuji, Y., Matsuda, T., and Nohda, S., 1989. Opening of the Japan back-arc basin by asthenosphere injection. Tectonophysics, 166:317-329.

Tokuyama, H., Suyemasu, M., Tamaki, K., Nishiyama, E., Kuramoto, S., Suyehiro, K., Kinoshita, H., and Taira, A., 1987. Report on DELP 1985 cruises in the Japan Sea. Part III: Seismic reflection studies in the Yamato Basin and the Yamato Rise area. Bull. Earthquake Res. Inst., Univ. Tokyo, 62:367-390.

Tosha, T., 1984. Paleomagnetism of northeast Japan. Chikyu (The Earth Monthly), 6:601-609 (in Japanese).

Tosha, T., and Hamano, Y., 1988. Paleomagnetism of Tertiary rocks from Oga Peninsula and the rotation of northeast Japan. Tectonics, 7:653-662.

Tsuchi, R. (Ed.), 1981. Neogene of Japan-its Biostratigraphy and Chronology: Shizuoka (Kurofune Printing Co., Ltd.).

Tsuchi, R., and IGCP-114 National Working Group of Japan, 1981. Bio- and chronostratigraphic correlation of Neogene sequences in the Japanese Islands. In Tsuchi, R. (Ed.), Neogene of Japan-its Biostratigraphy and Chronology: Shizuoka (Kurofune Printing Co.), 91-104.

Ujiie, H., and Ichikura, M., 1973. Holocene to uppermost Pleistocene planktonic foraminifers in a piston core from off the San'n District, Sea of Japan. Trans. Palaeont. Soc. Japan, New Ser., 9:137-150.

Uyeda, S., 1986. Facts, ideas, and open problems on trench-arc-backarc systems. In Wezel, F. C. (Ed.), The Origin of Arcs: Amsterdam (Elsevier), 435-460.

Uyeda, S., and Kanamori, H., 1979. Back-arc opening and mode of subduction. J. Geophys. Res., 84:1049-1061.

Uyeda, S., and Miyashiro, A., 1974. Plate tectonics and the Japanese Islands; a synthesis. Geol. Soc. Am. Bull., 85:1159-1170.

Von Herzen, R. P., Francis, T.J.G., and Becker, K., 1983. In situ large-scale electrical resistivity of ocean crust, Hole 504B. In Cann, J. R., Langseth, M., et al., Init. Repts. DSDP, 69: Washington (U.S. Govt. Printing Office), 237-244,

Watanabe, T., Langseth, M. G., and Anderson, R. N., 1977. Heat flow in back-arc basins of the Western Pacific. In Talwani, M., and Pitman, W. C. III (Eds.), Island Arcs, Deep Sea Trenches, and Back-Arc Basins: Washington (Am. Geophys. Union), 137-161.

Wesnousky, S. G., Scholz, C. H., and Shimakaki, K., 1982. Deformation of an island arc: rates of moment release and crustal shortening intraplate Japan determined from seismicity and Quaternary fault data. J. Geophys. Res., 87:6829-6852.

Worthington, L. V., 1981. The water masses of the World Ocean: some results of a fine-scale census. In Warren, B. A., and Wunsch, C. (Eds.), Evolution of Physical Oceanography: Cambridge (M.I.T. Press), 42-69.

Yaskawa, K., 1975. Paleolatitude and relative position of southwest Japan and Korea in the Cretaceous. Geophys. J. R. Astron. Soc., 43:835-846.

Yoshii, T., 1972. Terrestrial heat flow and features of the upper mantle beneath the Pacific and Sea of Japan. J. Phys. Earth, 20:271-285.

Yoshii, T., and Asano, S., 1972. Time-term analysis of explosion seismic data. J. Phys. Earth, 20:47-57. 